National Water-Quality Assessment Program

\title{
Water-Quality Assessment of Part of the Upper Mississippi River Basin, Minnesota and Wisconsin-Ground-Water Quality in the Prairie du Chien-Jordan Aquifer, 1996
}

Water-Resources Investigations Report 98-4248

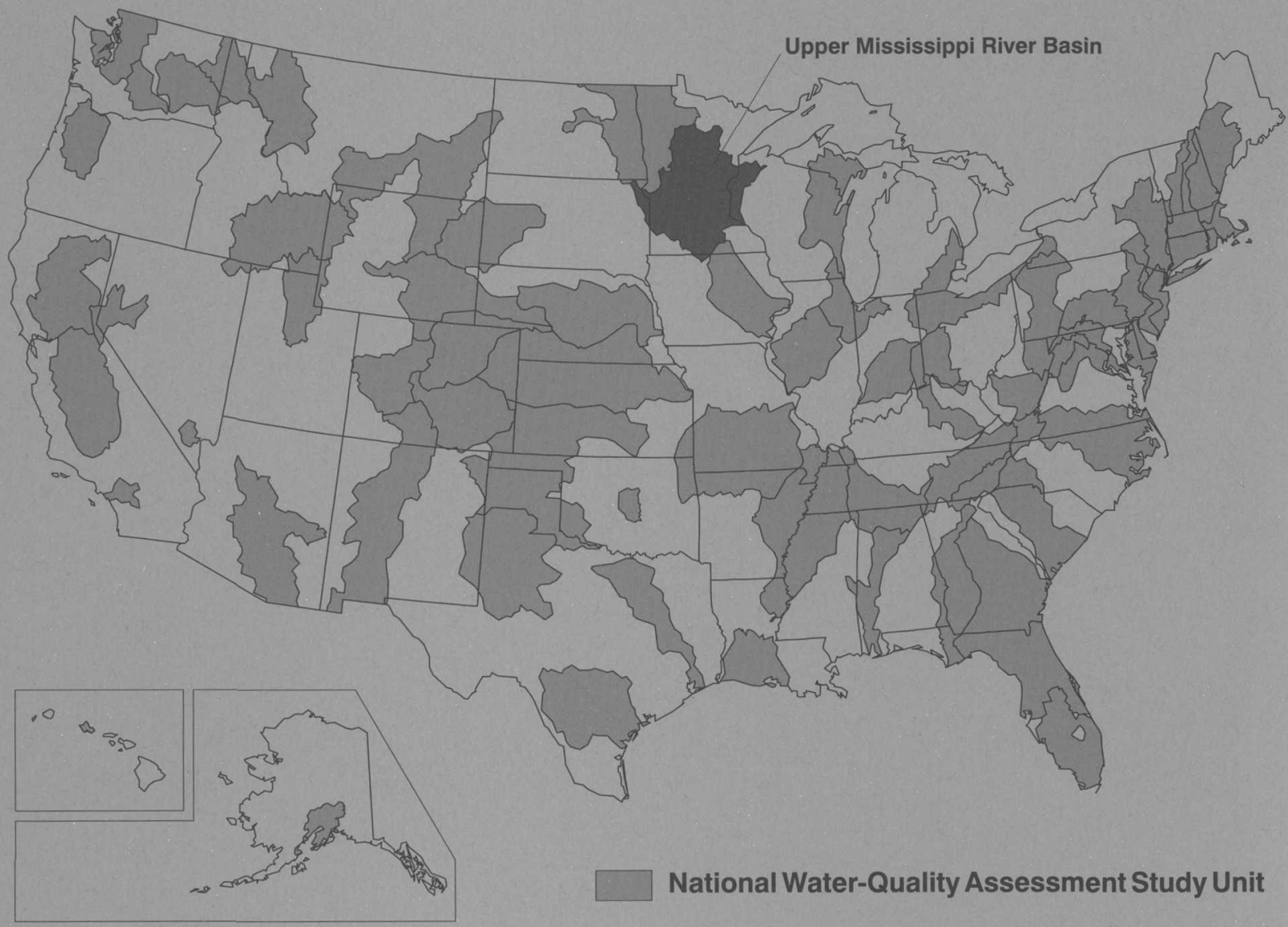

U.S. Department of the Interior

U.S. Geological Survey 


\title{
United States Department of the Interior
}

\author{
U.S. GEOLOGICAL SURVEY \\ Water Resources Division \\ 2280 Woodale Drive \\ Mounds View MN 55112 \\ (612) 783-3230 \\ email: stark@usgs.gov
}

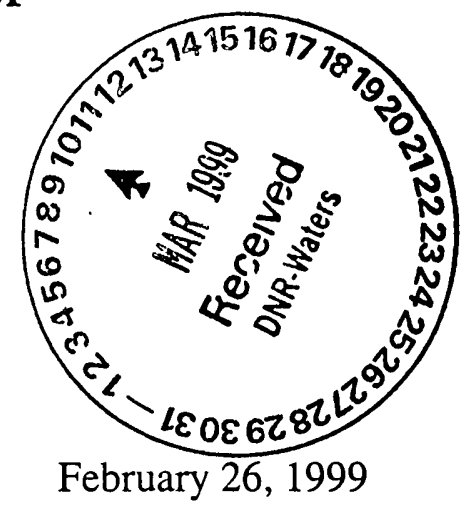

Dear Colleague,

Enclosed find our most recent report written as part of the U.S. Geological Survey's National Water-Quality Assessment (NAWQA) Program in the Upper Mississippi River Basin (UMIS), entitled "Water-Quality Assessment of Part of the Upper Mississippi River Basin, Minnesota and Wisconsin-Ground-Water Quality in the Prairie du Chien-Jordan Aquifer, 1996," by Alison L. Fong, William J. Andrews, and James R. Stark. This report describes chemical characteristics of water in the Prairie du Chien-Jordan aquifer, the principal aquifer in terms of source water to wells in the Twin Cities metropolitan area, and the effects of confining units on the quality of the water. Additional copies of the report, released as Water-Resources Investigations Report 98-4248, can be purchased from the U.S. Geological Survey, Branch of Information Services, Box 25286, Federal Center, Denver CO 80225-0286.

Sincerely,

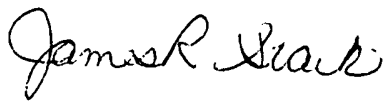

James R. Stark

Study Chief, UMIS NAWQA

Enclosure 



\section{Water-Quality Assessment of Part of the Upper Mississippi River Basin, Minnesota and Wisconsin-Ground-Water Quality in the Prairie du Chien-Jordan Aquifer, 1996}

By Alison L. Fong, William J. Andrews, and James R. Stark

Water-Resources Investigations Report 98-4248

National Water-Quality Assessment Program 


\section{U.S. Department of the Interior}

Bruce Babbitt, Secretary

\section{U.S. Geological Survey}

Charles G. Groat, Director

Use of product names is for descriptive purposes only and

does not constitute endorsement by the U.S. Geological Survey

Mounds View, Minnesota, 1998

For additional information write to:

District Chief

U.S. Geological Survey, WRD

2280 Woodale Drive

Mounds View MN 55112

Copies of this report can be purchased from:

\section{U.S. Geological Survey}

Branch of Information Services

Box 25286

Federal Center

Denver CO 80225

Information regarding the National Water-Quality Assessment Program (NAWQA)

is available on the Internet via the World Wide Web. You may connect to the

NAWOA Home Page using the Universal Resource Locator (URL) at:

http://wwwrvares.er.usgs.gov/nawqa/nawqa_home.html

Information about the Upper Mississippi River Basin Project of the NAWQA Program

is available on the World Wide Web at: http://wwwmn.cr.usgs.gov/umis/index.html

Water-Resources Investigations Report 98-4248 


\section{Forward}

The mission of the U.S. Geological Survey (USGS) is to assess the quantity and quality of the earth resources of the Nation and to provide information that will assist resource managers and policy makers at Federal, State, and local levels in making sound decisions. Assessment of water-quality conditions and trends is an important part of this overall mission.

One of the greatest challenges faced by waterresources scientists is acquiring reliable information that will guide the use and protection of the Nation's water resources. That challenge is being addressed by Federal, State, interstate, and local water-resource agencies and by many academic institutions. These organizations are collecting water-quality data for a host of purposes that include: compliance with permits and water-supply standards; development of remediation plans for a specific contamination problem; operational decisions on industrial, wastewater, or water-supply facilities; and research on factors that affect water quality. An additional need for water-quality information is to provide a basis on which regional and national-level policy decisions can be based. Wise decisions must be based on sound information. As a society we need to know whether certain types of water-quality problems are isolated or ubiquitous, whether there are significant differences in conditions among regions, whether the conditions are changing over time, and why these conditions change from place to place and over time. The information can be used to help determine the efficacy of existing water-quality policies and to help analysts determine the need for and likely consequences of new policies.

To address these needs, the Congress appropriated funds in 1986 for the USGS to begin a pilot program in seven project areas to develop and refine the National Water-Quality Assessment (NAWQA) Program. In 1991, the USGS began full implementation of the program. The NAWQA Program builds upon an existing base of water-quality studies of the USGS, as well as those of other Federal, State, and local agencies. The objectives of the NAWQA Program are to:

- Describe current water-quality conditions for a large part of the Nation's freshwater streams, rivers, and aquifers.

- Describe how water quality is changing over time.
- Improve understanding of the primary natural and human factors that affect water-quality conditions.

This information will help support the development and evaluation of management, regulatory, and monitoring decisions by other Federal, State, and local agencies to protect, use, and enhance water resources.

The goals of the NAWQA Program are being achieved through ongoing and proposed investigations of 60 of the Nation's most important river basins and aquifer systems, which are referred to as study units. These study units are distributed throughout the Nation and cover a diversity of hydrogeologic settings. More than two-thirds of the Nation's freshwater use occurs within the 60 study units and more than two-thirds of the people served by public water-supply systems live within their boundaries.

National synthesis of data analysis, based on aggregation of comparable information obtained from the study units, is a major component of the program. This effort focuses on selected water-quality topics using nationally consistent information. Comparative studies will explain differences and similarities in observed water-quality conditions among study areas and will identify changes and trends and their causes. The first topics addressed by the national synthesis are pesticides, nutrients, volatile organic compounds, and aquatic biology. Discussions on these and other waterquality topics will be published in periodic summaries of the quality of the Nation's ground and surface water as the information becomes available.

This report is an element of the comprehensive body of information developed as part of the NAWQA Program. The program depends heavily on the advice, cooperation, and information from many Federal, State, interstate, Tribal, and local agencies and the public. The assistance and suggestions of all are greatly appreciated.

Robert M. Hirsch

Chief Hydrologist 


\section{Contents}

Abstract.

Introduction

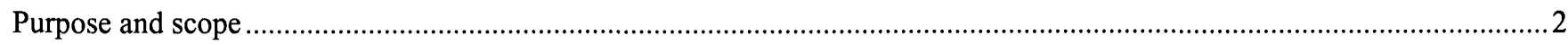

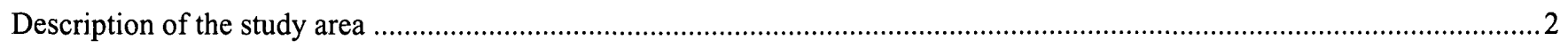

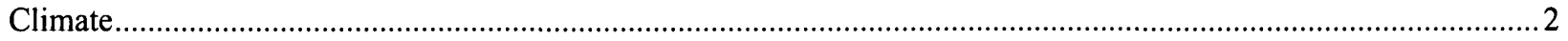

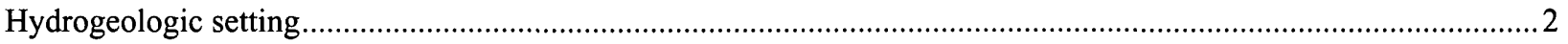

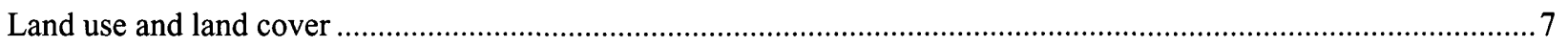

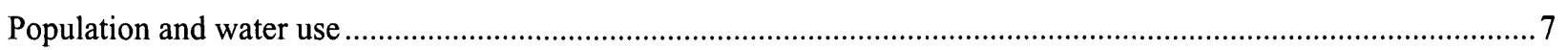

Methods of well selection, sample collection, and data analysis .............................................................................. 7

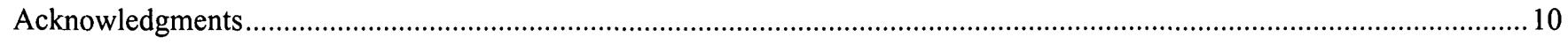

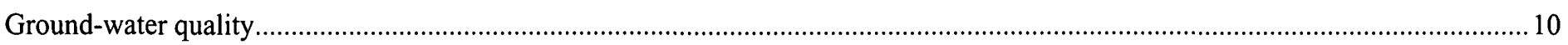

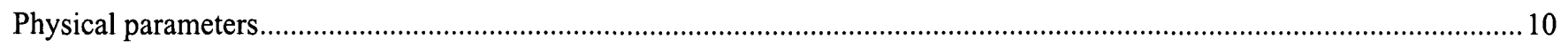

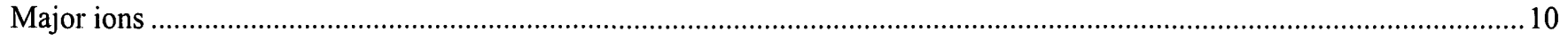

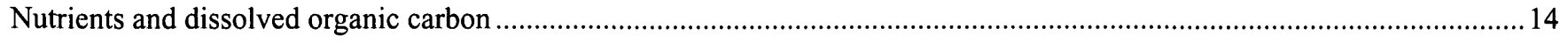

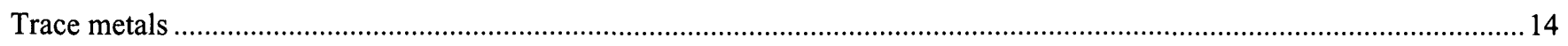

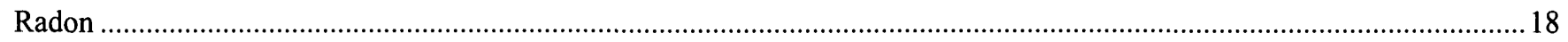

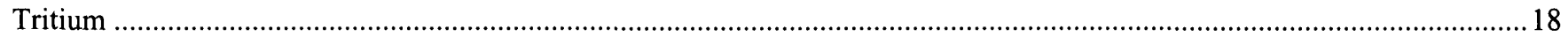

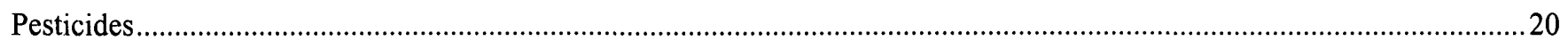

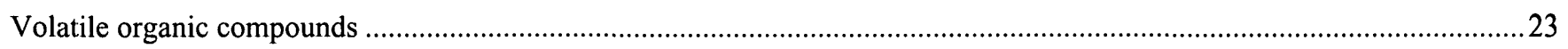

Implications of water-quality variability between confined and unconfined portions of the Prairie du Chien-Jordan aquifer ...............26

Water-quality variability between the Prairie du Chien Group and the Jordan Sandstone portions of the Prairie du

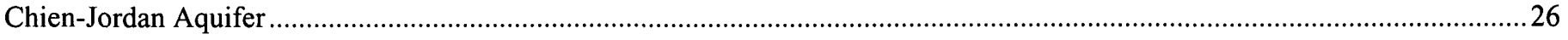

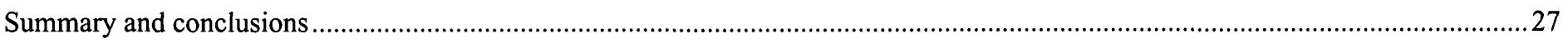

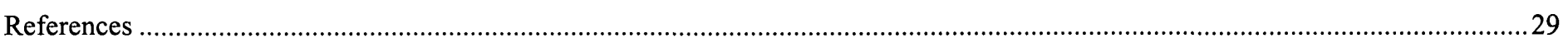

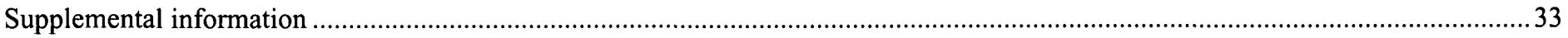

\section{Illustrations}

Figures 1-3. Maps showing:

1. Location of the Upper Mississippi River study unit, Prairie du Chien-Jordan aquifer study area, and estimated

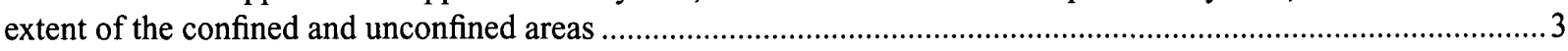

2. Surficial hydrogeology in the Prairie du Chien-Jordan aquifer study area ...................................................... 4

3. Bedrock hydrogeology in the Prairie du Chien-Jordan aquifer study area .......................................................5

4. Generalized hydrogeologic column showing aquifers and confining units in the study area ........................................6

5. Map showing land use and land cover in the Prairie du Chien-Jordan aquifer study area .......................................... 8

6-7. Boxplots showing:

6. Field measurements of physical parameters in water samples from Prairie du Chien-Jordan aquifer study area wells

7. Concentrations of dissolved major ions in water samples from Prairie du Chien-Jordan aquifer study area wells

8. Piper diagrams showing major ion composition of water samples from Prairie du Chien-Jordan aquifer study area wells 


\section{Illustrations--continued}

9. Boxplots showing concentrations of dissolved nutrients and dissolved organic carbon in water samples from Prairie du

Chien-Jordan aquifer study area wells

10. Map showing locations of wells and nitrate concentrations in water samples from wells completed in the Prairie du Chien-Jordan aquifer.

11-12. Boxplots showing:

11. Concentrations of trace metals in water samples from Prairie du Chien-Jordan aquifer study area wells

12. Concentrations of radon in water samples from Prairie du Chien-Jordan aquifer study area wells

13. Map showing locations of wells and radon concentrations in water samples from wells completed in the Prairie du Chien-Jordan aquifer

14. Boxplots showing concentrations of tritium in water samples from Prairie du Chien-Jordan aquifer study area wells .....20

15. Map showing locations of wells and tritium concentrations in water samples from wells completed in the Prairie du Chien-Jordan aquifer

16. Map showing locations of Prairie du Chien-Jordan aquifer study area wells with water samples having detectable concentrations of pesticide compounds

17. Barchart showing frequencies of detection of pesticide compounds in water samples from Prairie du Chien-Jordan aquifer study area wells.

18. Map showing locations of Prairie du Chien-Jordan aquifer study area wells with water samples having detectable concentrations of volatile organic compounds

19. Barchart showing frequencies of detection of volatile organic compounds in water samples from Prairie du Chien-Jordan aquifer study area wells

\section{Tables}

1. Medians, standard deviations, and ranges in well characteristics and values of physical parameters in water samples from Prairie du Chien-Jordan study area wells.

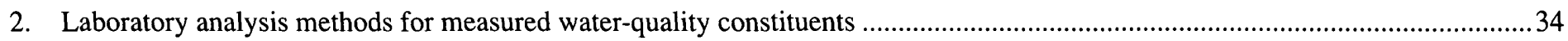

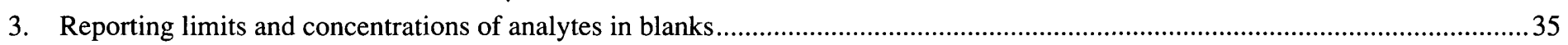

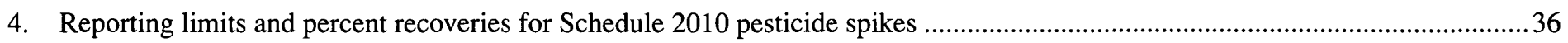

5. Reporting limits and percent recoveries for custom method 9090 volatile organic compound spikes ...........................................38

6. Reporting limits and concentrations of compounds with greater than five percent differences in concentrations in replicate samples

7. Medians, standard deviations, and ranges in values of concentrations of major ions dissolved in water samples from Prairie du Chien-Jordan study area wells.

8. Number of samples with detectable concentrations, reporting limits, median values, standard deviations, and ranges in concentrations of nutrients and dissolved organic carbon in water samples from wells in the unconfined and confined portions of the Prairie du Chien-Jordan study area

9. Number of samples with detectable concentrations, reporting limits, median values, standard deviations, ranges in concentrations, and maximum contaminant levels of trace metals in water samples from wells in the unconfined and confined portions of the Prairie du Chien-Jordan study area

10. Pesticide compounds analyzed in water samples, by chemical class

11. Reporting limits, number of samples with detectable concentrations, ranges in concentrations, and maximum contaminant levels of pesticide compounds in water samples from Prairie du Chien-Jordan study area wells.

12. Volatile organic compounds analyzed in water samples, by chemical class.

13. Reporting limits, number of samples with detectable concentrations, ranges in concentrations, and maximum contaminant levels of volatile organic compounds detected in water samples from Prairie du Chien-Jordan study area wells ..... 
Conversion Factors, Abbreviated Water-Quality Units, and Abbreviations

$\begin{array}{rll}\text { Multiply } & \text { By } & \text { To obtain } \\ \text { inch (in.) } & 25.4 & \text { millimeter } \\ \text { foot (ft) } & 0.3048 & \text { meter } \\ \text { square mile }\left(\mathrm{mi}^{2}\right) & 2.590 & \text { square kilometer } \\ \text { gallon } & 3.785 & \text { liter } \\ \text { million gallons per day (mgal/d) } & 3.785 & \text { million liters per day } \\ \text { degrees Fahrenheit }\left({ }^{\circ} \mathrm{F}\right) & \left.\text { (temperature }{ }^{\circ} \mathrm{F}-32\right) / 1.8 & \text { degrees Celsius }\end{array}$

Chemical concentrations of substances in water are given in metric units of milligrams per liter $(\mathrm{mg} / \mathrm{L})$ and micrograms per liter $(\mu \mathrm{g} / \mathrm{L})$. Milligrams per liter is a unit expressing the concentration of chemical constituents in solution as mass (milligrams) of solute per unit volume (liter) of water. Micrograms per liter is a unit expressing the concentration of chemical constituents in solution as mass (micrograms) of solute per unit volume (liter) of water.

Abbreviations used in this report:

ATSDR-Agency for Toxic Substances and Disease Registry, an agency of the U.S. Department of Health and Human Services

$D I$-Deionized water

DOC—Dissolved organic carbon

GIS-Geographic Information System

GWSI-Ground-Water Site Inventory

$J D N$ - Jordan

$M C L-$ Maximum Contaminant Level, a health-based water-quality standard set by the USEPA

MPCA—Minnesota Pollution Control Agency

NADP/NTN-National Acidic Deposition Program/National Trends Network

NAWQA-National Water-Quality Assessment

$N T U-$ Nephelometric Turbidity Units

$P D C J$-Prairie du Chien-Jordan

$P D C$ - Prairie du Chien

$Q A / Q C$-Quality-assurance/quality-control

$S I$-Saturation indices

$S M C L-$ Secondary maximum contaminant level, an unenforceable guideline regarding taste, odor, color, and certain other non-aesthetic effects of drinking water set by the USEPA

TCMA-Twin Cities metropolitan area

UMIS-Upper Mississippi River Basin study unit

USEPA-U.S. Environmental Protection Agency

USGS-U. S. Geological Survey

VOC-Volatile organic compound 


\title{
Water-Quality Assessment of Part of the Upper Mississippi River Basin, Minnesota and Wisconsin-Ground-Water Quality in the Prairie du Chien-Jordan Aquifer, 1996
}

\author{
By Alison L. Fong, William J. Andrews, and James R. Stark
}

\begin{abstract}
The Prairie du Chien-Jordan (PDCJ) aquifer (Prairie du Chien-Trempealeau aquifer in Wisconsin), composed of dolomite and sandstone of Cambrian to Ordovician age, is the principal bedrock aquifer in the Upper Mississippi River study unit of the National Water-Quality Assessment (NAWQA) Program. The aquifer supplies approximately 75 percent of the ground water withdrawn in the area. In certain areas, the aquifer is overlain by bedrock or glacial deposits having low hydraulic conductivity (termed "confined portion" of the aquifer in this report). In other areas the aquifer is overlain by glacial sand and gravel deposits having greater hydraulic conductivity (termed "unconfined portion" of the aquifer in this report). Differences in the hydrogeologic characteristics of these overlying units have potential to affect the downward movement of water and of contaminants into the aquifer from the land surface.
\end{abstract}

Ground-water samples were collected from 50 domestic wells completed in this aquifer in July, August, and September of 1996 as part of the U.S. Geological Survey's National WaterQuality Assessment Program. The purpose of this report is to describe the chemical characteristics of water in the PDCJ aquifer and to summarize the differences in water quality in confined and unconfined portions of the aquifer. Twenty-five wells were sampled in each portion of the aquifer. Water samples from the wells were measured for physical parameters and analyzed for concentrations of major ions, nutrients, dissolved organic carbon, trace metals, radon, tritium, pesticides, and volatile organic compounds.

Differences in anthropogenic and naturally occurring materials in water between confined and unconfined portions of the PDCJ aquifer are small and frequently the differences are not statistically significant at the 95 percent confidence level. Dissolved oxygen concentrations were slightly less and specific conductances and alkalinities were slightly greater in water in the confined portion of the aquifer. Only the differences in specific conductance and alkalinity, however, were statistically significant at the 95 percent confidence level (two sample t-test). Concentrations of most major ions were generally greater in water from the confined portion of the aquifer.

Nitrate (nitrite plus nitrate as $\mathrm{N}$ ) and phosphorus were generally greater in the unconfined portion of the PDCJ aquifer although the differences were not statistically significant at the 95 percent confidence level (nonparametric Mann-Whitney test).
In the confined portion of the aquifer no samples exceeded the maximum contaminant level of 10 milligrams per liter for nitrate. In the unconfined portion of the aquifer nitrate in two samples exceeded the maximum contaminant level of 10 milligrams per liter. Phosphorus concentrations were generally about an order of magnitude less than nitrate concentrations.

Iron and manganese concentrations commonly exceeded the secondary maximum contaminant levels set by the U.S. Environmental Protection Agency and were generally greater in the confined portion of the PDCJ aquifer, although the differences were not statistically significant at the 95 percent confidence level (nonparametric Mann-Whitney test). Radon concentrations were greater in the confined portion of the aquifer than in the unconfined portion, although the difference was not statistically significant at the 95 percent confidence level (two sample t-test), with medians of 500 and 340 picoCuries per liter, respectively. Sixty-six percent of the radon concentrations were greater than the suspended maximum contaminant level of 300 picoCuries per liter. Tritium concentrations indicate that water in the unconfined portion of the PDCJ aquifer may have been recharged more recently than water in the confined portion of the aquifer, although differences in tritium concentrations between confined and unconfined portions of the aquifer were not statistically significant at the 95 percent confidence level (nonparametric MannWhitney test). Atrazine and its metabolite, deethylatrazine, were the most frequently detected pesticide compounds in water samples from the PDCJ aquifer. Volatile organic compounds were detected in 41 of the 50 water samples, but none of the concentrations exceeded 1 microgram per liter. Concentrations of volatile organic compounds were slightly greater in the unconfined portion, although the differences in detection rates were not statistically significant at the 95 percent confidence level (nonparametric Mann-Whitney test). Carbon disulfide and methyl chloride were the most frequently detected volatile organic compounds.

Water in the unconfined portion of the PDCJ aquifer in Minnesota and Wisconsin appears to be affected to a greater degree by anthropogenic activities than water in the confined portion of the aquifer. Water in the confined portion has a longer residence time and greater concentrations of dissolution products of minerals. In general, however, differences in anthropogenic and naturally occurring materials among confined and unconfined portions of the aquifer are small and frequently not significantly different. 


\section{Introduction}

In 1991, the USGS began full implementation of the NAWQA program. The long-term goals of NAWQA are to describe the status of and trends in the quality of large representative parts of the Nation's surface- and ground-water resources and to identify the major natural and anthropogenic factors that affect the quality of these resources. To meet these goals, nationally consistent data useful to policy makers, scientists and managers are being collected and analyzed. Because assessment of the water quality in the entire Nation is impractical, major activities of NAWQA take place within a set of hydrologic systems called study units. Study units comprise diverse hydrologic systems of river basins, aquifer systems, or both.

The UMIS study unit (fig. 1), which encompasses an area of about 47,000 $\mathrm{mi}^{2}$, includes the entire drainage area of the Upper Mississippi River Basin from the headwaters to the outlet of Lake Pepin. The UMIS study unit includes areas of agricultural lands, forests, wetlands, prairies, and a major urban areathe TCMA (with a population of approximately 2,300,000) (Stark and others, 1996). Water quality of the Upper Mississippi River Basin, which includes the headwaters of the largest river system in the Nation, is of concern due to reliance on surface water by major municipalities in the basin and due to the necessity of good quality water to maintain the health of aquatic ecosystems. Ground water is the principal source of potable water to smaller municipalities and domestic water systems in the study unit. Ground water in sand and gravel aquifers of glacial and alluvial origins and in nearsurface bedrock aquifers is particularly susceptible to degradation from anthropogenic activities.

Activities during the first phase of NAWQA for this study unit (1994-99) are focused principally on the effects of the TCMA on water quality and aquatic ecosystems. The Prairie du Chien-Jordan (PDCJ) aquifer is the primary source of ground water for domestic wells and public water supplies in the TCMA, supplying approximately 75 percent of the ground water withdrawn in the area (Stark and others, 1996; Metropolitan Council, 1992).

\section{Purpose and Scope}

The purpose of this report is to describe the chemical characteristics and the effects of confinement of water in the PDCJ aquifer in the UMIS study unit. The study area (fig. 1), as defined for this report, consists of the part of the UMIS study unit underlain by the PDCJ aquifer in areas where the aquifer is an important source of water to domestic, commercial, industrial, and irrigation wells. Fifty domestic wells completed in the aquifer were sampled during July, August, and September of 1996-25 in portions of the aquifer overlain by confining units consisting of bedrock or glacial deposits (termed "confined portion" of the aquifer in this report) and 25 in portions of the aquifer that are not overlain by confining units (termed "unconfined portion" of the aquifer in this report) (fig. 1). Water samples were analyzed for nearly 200 water-quality constituents, including physical parameters, major ions, nutrients, DOC, trace metals, radon, tritium (in selected samples), pesticides, and VOCs. Waterquality samples from the wells were used to evaluate the quality of water in the aquifer and the influence of overlying confining units. Differences in water quality between portions of the aquifer overlain, and not overlain, by confining units are summarized in this report. In addition, a comparison of water quality between the Prairie du Chien (PDC) Group and the Jordan (JDN) Sandstone (stratigraphic units containing the aquifer) is presented.

\section{Description of the Study Area}

The presence and distribution of the analyzed constituents in ground water can be affected by the environmental setting of the study area. Major variables that can influence ground-water quality include climate, hydrogeologic setting, land use and land cover, population and water use. These variables are described for the study unit in Stark and others (1996).

\section{Climate}

Seasonal fluctuations in temperature and rainfall can affect the solubility of VOCs in rainfall, volatilization of VOCs to the atmosphere, seasonal loadings of pesticides in rainfall, relative amounts of runoff and infiltration, and processes such as mineral dissolution and precipitation, sorption, and denitrification, which can affect the quality of ground water. Average monthly temperatures in the study area range from about $10^{\circ} \mathrm{F}$ in January to greater than $70^{\circ} \mathrm{F}$ in July (Minnesota State Climatologist, electronic commun., 1995). Average annual precipitation is between 29 and 32 in. (Minnesota State Climatologist, electronic commun., 1995). About threefourths of the annual precipitation falls from May through September (Baker and others, 1979). Mean annual free-water surface evaporation ranges from 34 to 36 in. (Farnsworth and others, 1982).

\section{Hydrogeologic Setting}

The presence and concentrations of many constituents in ground water are affected by the hydraulic conductivity and chemical composition of overlying unconsolidated deposits and bedrock units. Soils in the study area include light, well-drained psamments, alfisols, and poorly-drained histosols (Stark and others, 1996). Beneath the soils, the study area is mantled with less than 50 to greater than $450 \mathrm{ft}$ of glacial and alluvial deposits (fig. 2) including sand and gravel (glacial outwash and alluvium), and glacial tills deposited primarily by the Des Moines Lobe (in the west) and by the Superior Lobe (in the northeast) (Norvitch and others, 1973; Bloomgren and others, 1989; Meyer and Hobbs, 1989; Schoenberg, 1990). Unconsolidated deposits in the study area are underlain by up to $1,000 \mathrm{ft}$ of sedimentary strata (fig. 3) ranging in age from Precambrian to Devonian. Sedimentary units in the study area are underlain by so-called "basement" units of metamorphic and igneous rocks of Precambrian age. Underlying the TCMA, bedrock units fill a concave depression known as the Twin Cities Basin. The terms for rock units and hydrogeologic units in the study area vary slightly between Minnesota and Wisconsin (fig. 4). In addition, there are 


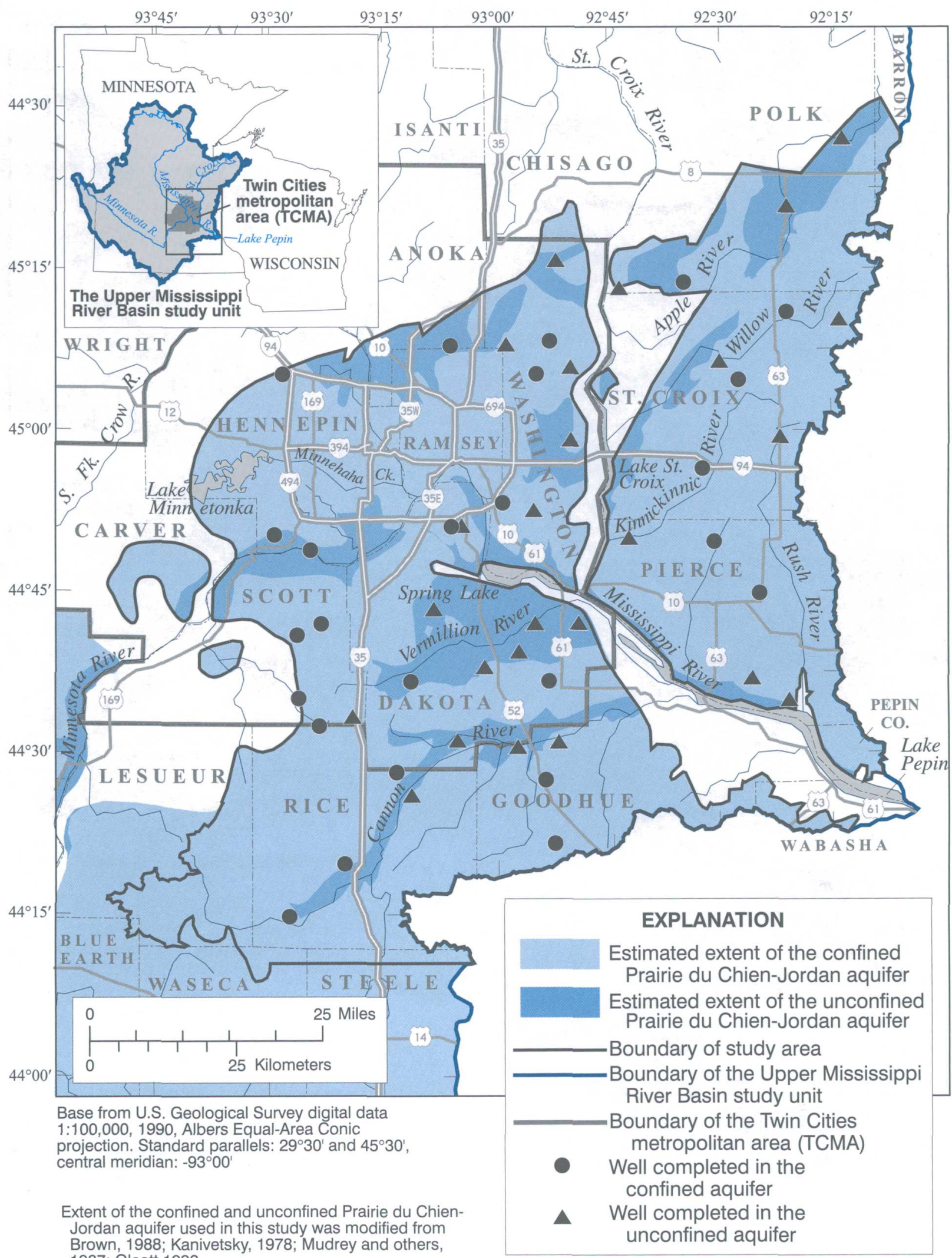

Brown, 1988; Kanivetsky, 1978; Mudrey and others,

1987; Olcott,1992.

Figure 1.--Location of the Upper Mississippi River Basin study unit, Prairie du Chien-Jordan aquifer study area, and estimated extent of the confined and unconfined areas. 


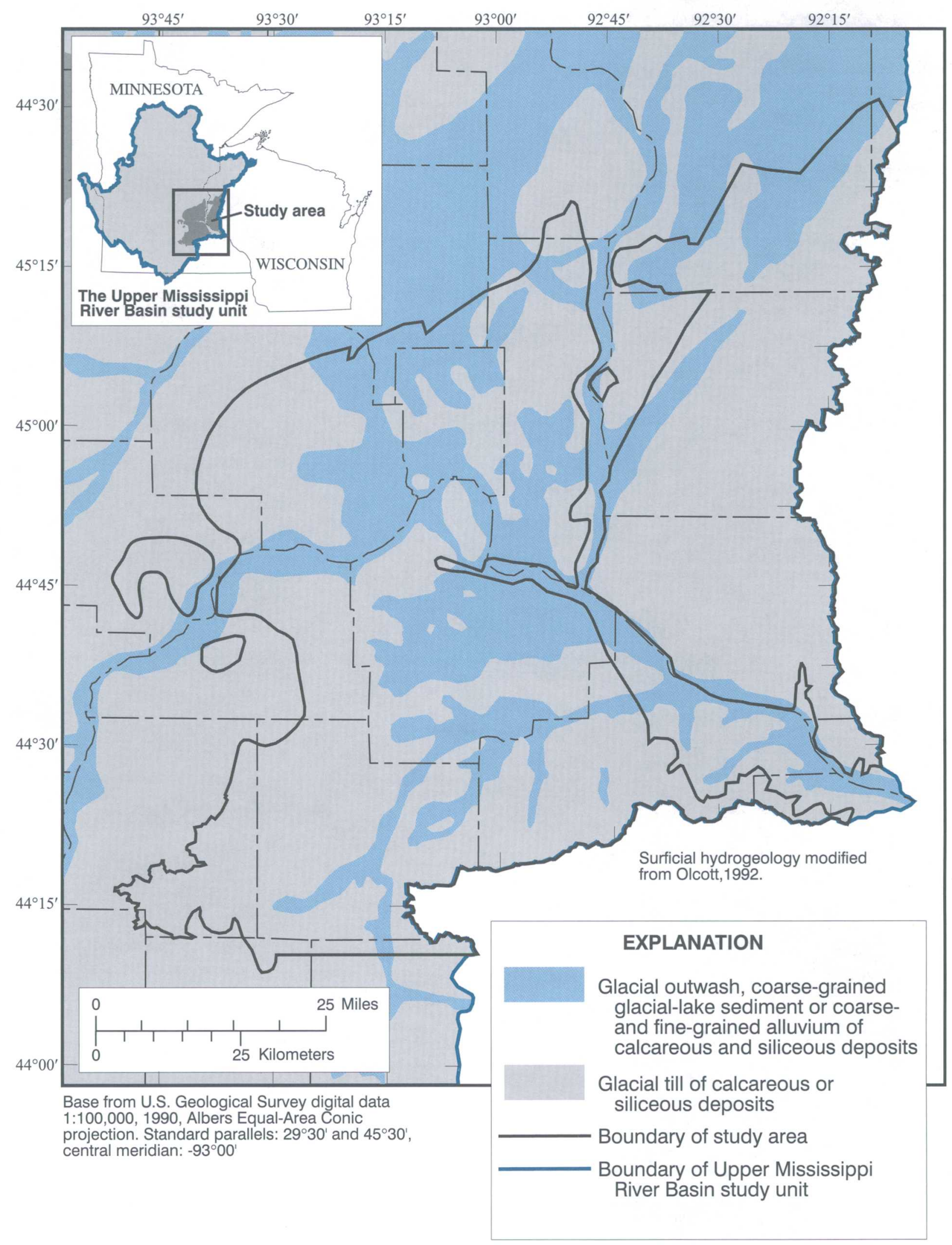

Figure 2.--Surficial hydrogeology in the Prairie du Chien-Jordan aquifer study area 


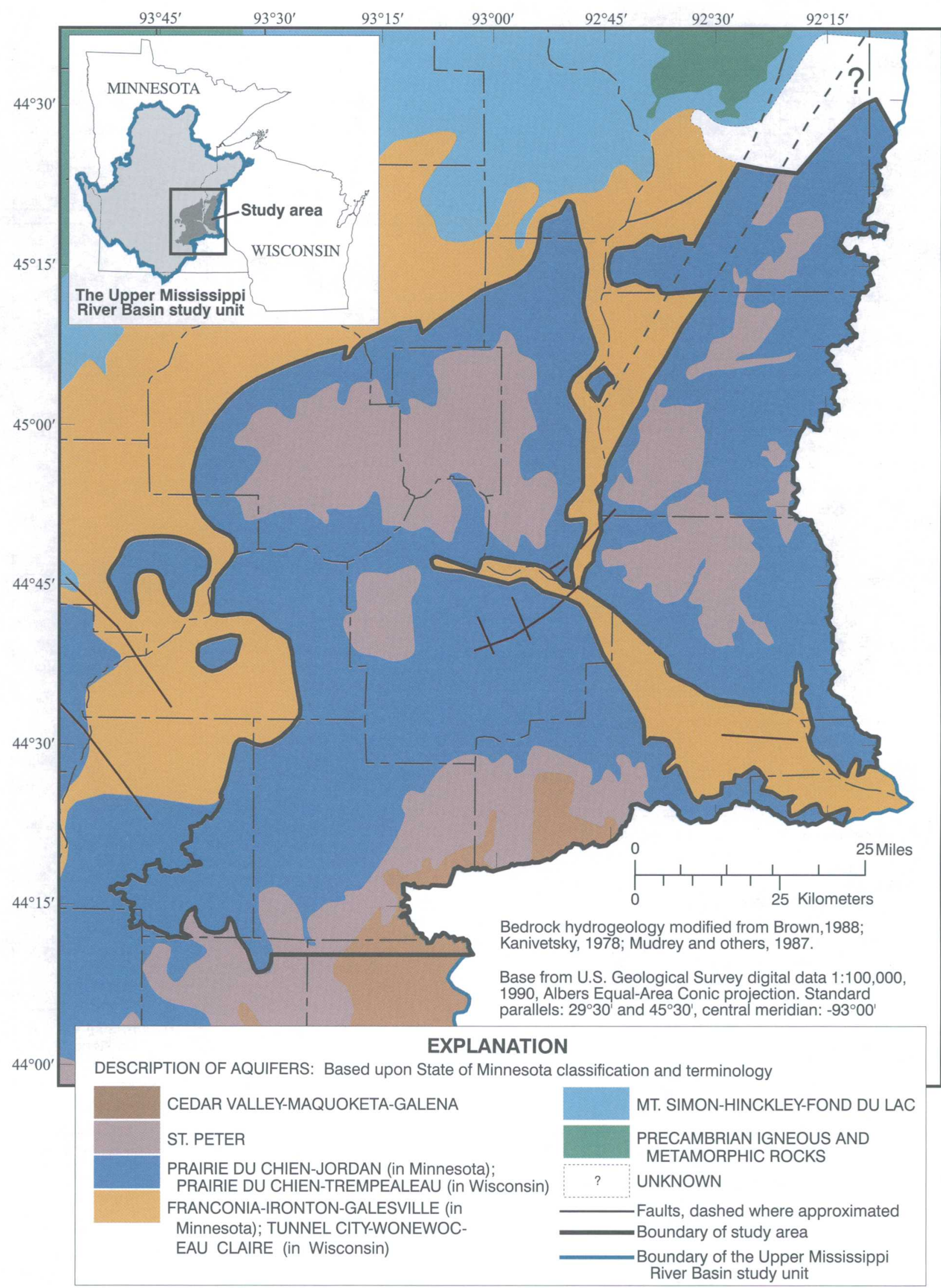

Figure 3.--Bedrock hydrogeology in the Prairie du Chien-Jordan aquifer study area. 


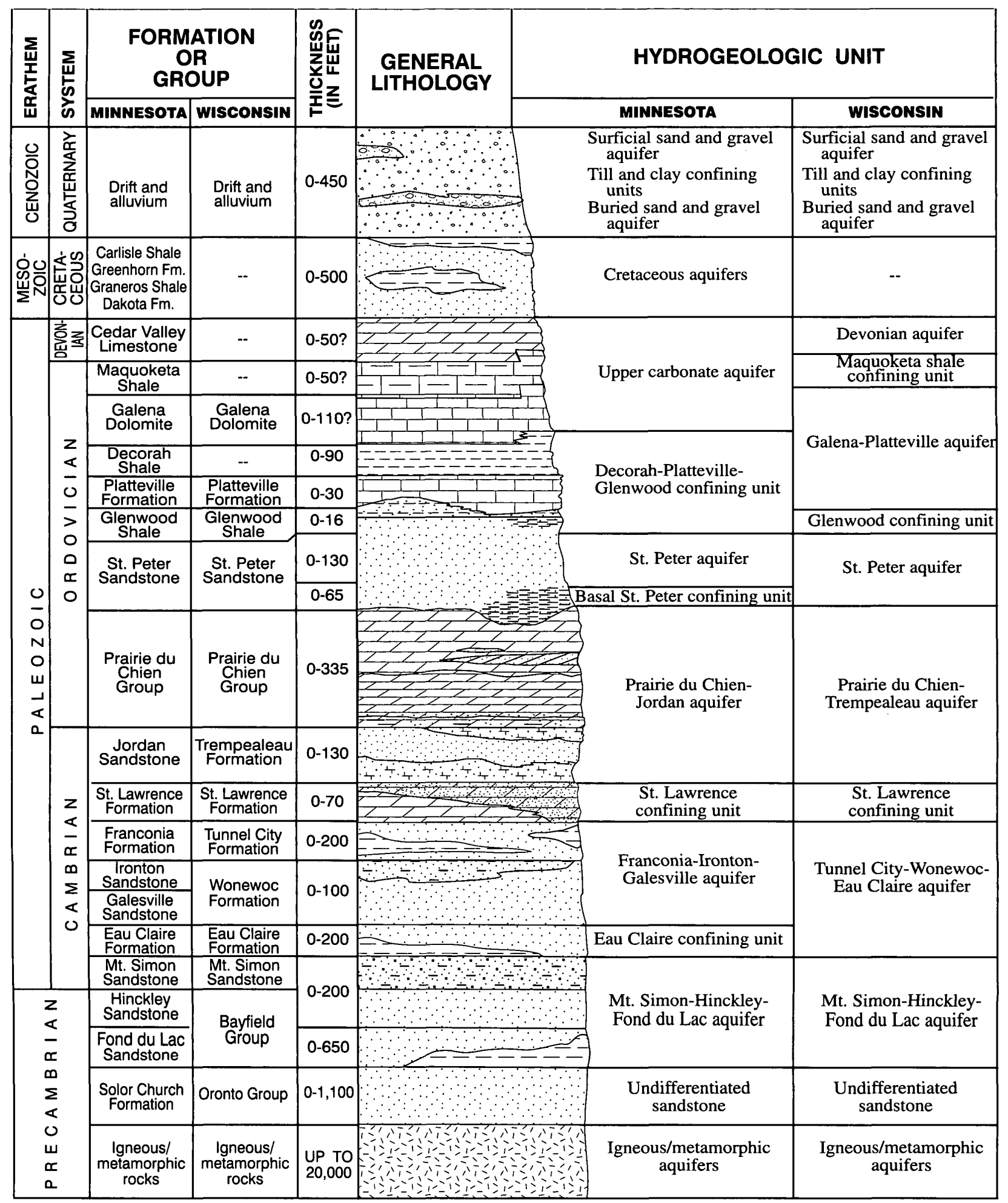

\section{EXPLANATION OF GENERAL LITHOLOGY}

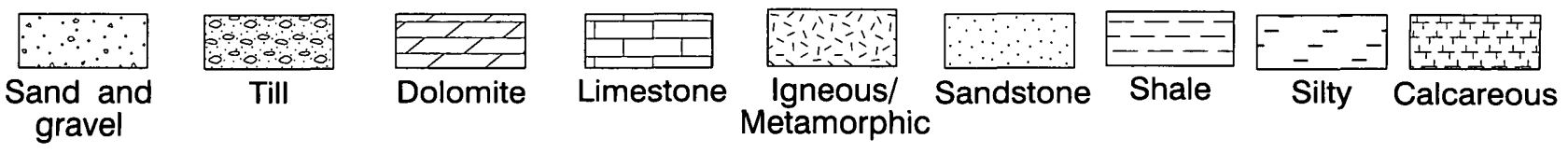

Figure 4.--Generalized hydrogeologic column showing aquifers and confining units in the study area (modified from Delin and Woodward, 1984; Green, 1977; Olcott, 1992). 
minor differences in the ways in which rock units and hydrogeologic units are grouped within a given term. In this report, terms commonly used in Minnesota are used. The PDCJ aquifer consists of up to $335 \mathrm{ft}$ of fractured sandy dolomite of the PDC Group of Ordovician age, and the underlying quartz sandstone of the JDN Sandstone of Cambrian age (fig. 4). The PDC is karstic, with ground-water flow occurring mainly through joints, fractures, and solution cavities, whereas flow in the JDN is primarily through the intergranular pore spaces and some joint partings (Delin and Woodward, 1984). The PDC and the JDN are in effective hydraulic connection and have traditionally been considered a single aquifer (Delin and Woodward, 1984; Young, 1992a; Young, 1992b). On a regional scale they have similar hydraulic heads and water-level fluctuations; however, the lower part of the PDC may serve locally as a partial confining unit (Setterholm and others, 1991) for the JDN. On a local basis, aquifer heterogeneity can create vertical hydraulic-head differences between the two stratigraphic units. These differences, combined with differences in the mineralogy and petrology between the two units, can result in small differences in the quality of water between the units.

The PDCJ aquifer is overlain by younger bedrock units or by unconsolidated sands or tills of varying thicknesses throughout its extent (figs. 2, 3 and 4). Although the sequence of glaciation in the study area is complex, glacial deposits in the western portion tend to be associated with the Des Moines Lobe and are more clay-rich than glacial deposits in the eastern portion of the study area, which are associated with the Superior Lobe. The aquifer is generally closer to land surface in the eastern portion of the study unit where glacial till confining units are less extensive. The aquifer is incised in many areas by alluvium and glacial-outwash-filled valleys (Schoenberg, 1990). The lower part of the overlying St. Peter Sandstone, where it exists, is considered a confining unit in the study area (Olcott, 1992). For this report, the PDCJ is considered to be confined where it is overlain by younger bedrock units or by at least $10 \mathrm{ft}$ of clay or clay-rich glacial till and is considered to be unconfined where these units are absent.

\section{Land Use and Land Cover}

Land use and land cover in the study area consists primarily of agricultural lands, forests, and urban areas (fig. 5). Land use and land cover can influence the presence and distribution of constituents in ground water (Stark and others, 1996). Agricultural land uses can be sources of nutrients and pesticides to ground water. Urban and suburban land uses contribute nitrogen and phosphorus to ground water through leaching of fertilizers applied to residential lawns and to parks and golf courses. Landfills and waste sites can also contribute contaminants to ground water. Roadways and railroads can be sources of chloride from applications of salt for de-icing, of herbicides applied in their rights-of-way, and of VOCs emitted to the air or spilled on their surfaces. Chemicals used by homeowners can also be sources of VOCs to ground water. Commercial and industrial establishments may also discharge VOCs and other substances to the atmosphere or to the land surface. The most concentrated area of potential contaminant sources in the study area is the TCMA.

\section{Population and Water Use}

The estimated population of the study area in 1994 was about 3.2 million people (Missouri State Census Data Center, U.S. Bureau of the Census data, electronic commun., 1997). Approximately 75 percent of the population resides in the TCMA (U.S. Bureau of the Census, 1991). In 1990, throughout the TCMA, an average of 324 million gallons of ground water per day were used. The PDCJ aquifer is the principal source of water for public-supply wells in suburban communities surrounding the Twin Cities, supplying approximately 75 percent of the ground water withdrawn (243 $\mathrm{mgal} / \mathrm{d}$ ) in the TCMA in 1990 (Andrews and others, 1995a; Metropolitan Council, 1992). The PDCJ aquifer is also the primary source of water for domestic wells inside and outside of the TCMA in the study area.

\section{Methods of Well Selection, Sample Collection, and Data Analysis}

The 50 sampled domestic wells were selected by using a GIS-based random, equal-area algorithm (Scott, 1990). For the Minnesota portion of the study area, the County Well-Index database of the Minnesota Geological Survey and the Ground-Water Site Inventory (GWSI) database of the USGS were used to compile a list of suitable wells, from which primary and alternate wells were selected for confined and unconfined portions of the aquifer. For the Wisconsin portion of the study area, relatively few suitable wells were listed in GWSI. Instead, suitable wells near randomly selected sampling locations were identified from well logs supplied by the Wisconsin Department of Natural Resources. Wells were selected based on lithologic information provided on the well logs and not based on the generalized stratigraphic information shown on figure 1. Consequently, wells designated as being completed in confined and unconfined portions of the aquifer do not precisely match the information provided on figure 1 .

Physical parameters measured during sampling included depth to water, water temperature, $\mathrm{pH}$, specific conductance, dissolved oxygen, turbidity, and alkalinity (table 1, in the Supplemental Information section). Water samples were collected in sealed systems utilizing Teflon tubing and stainless steel fittings, according to NAWQA protocols (Koterba and others, 1995). The wells were purged by pumping three to five standing volumes of water from the wells using the existing pumping systems. The stability of water chemistries were verified through periodic measurements of physical parameters made while purging the wells. Water samples to be analyzed for major ions, nutrients, DOC, trace metals, radon, tritium, pesticides, and VOCs were shipped to the USGS National Water-Quality Laboratory in Arvada, Colorado where analyses were done according to USGS analytical protocols for analysis, quality assurance, and quality control (table 2, in the Supplemental Information section). 


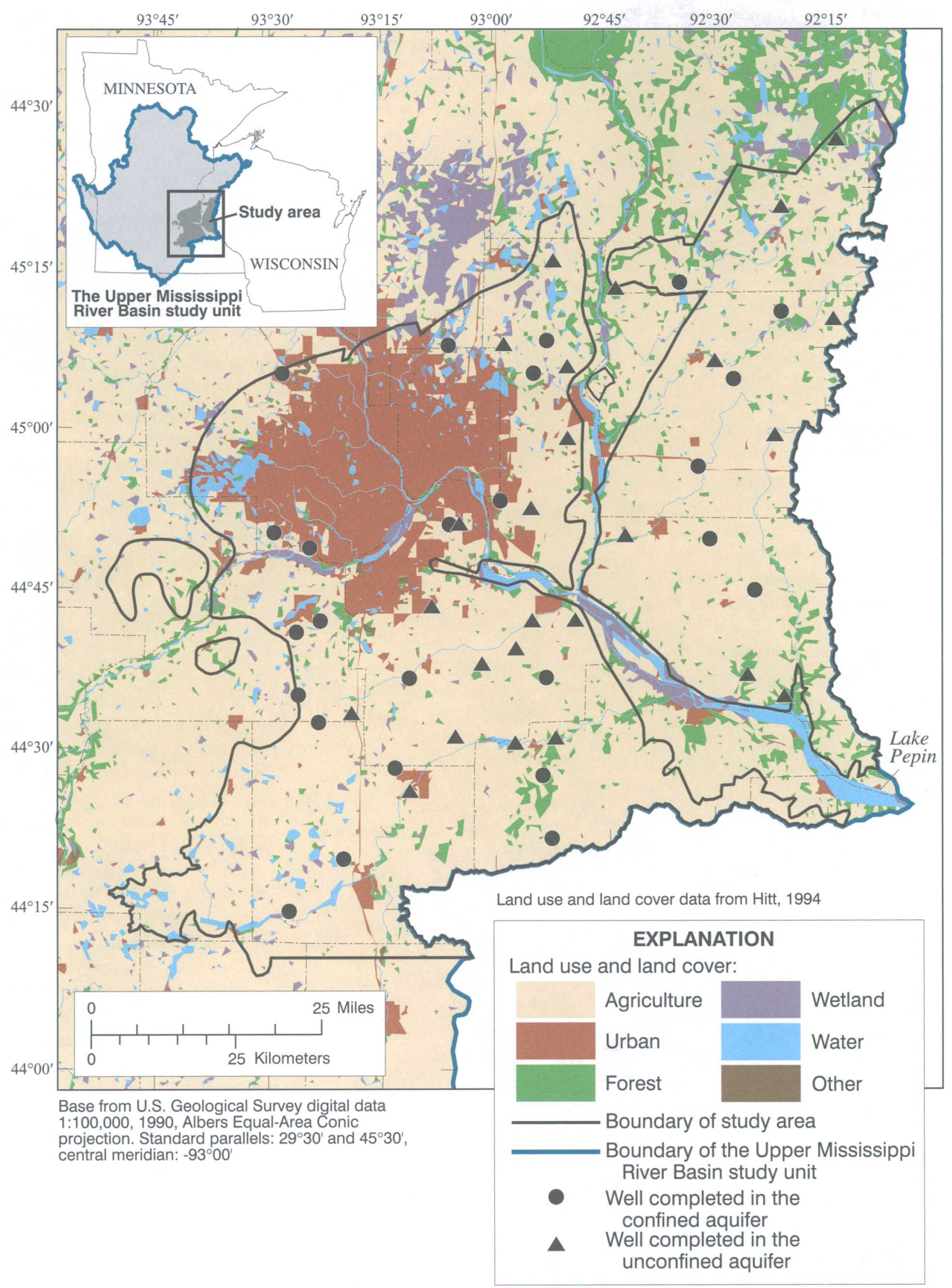

Figure 5.--Land use and land cover in the Prairie du Chien-Jordan aquifer study area. 
Environmental-sample data were compared to quality-assurance data that were used to verify the effectiveness of cleaning methods of sampling equipment and lack of cross contamination between wells (blank samples). Replicate samples were collected from selected wells to check the stability of water quality and to check the efficacy of purging procedures. Spiked samples were submitted for selected pesticide and VOC samples to measure changes in concentrations during shipment and to check analytical recoveries.

Twelve quality-assurance/qualitycontrol (QA/QC) samples were collected. These samples included three field/equipment blanks, one VOC trip blank, one source-solution blank, three spikes (pesticides and VOCs), and four replicates. The standard NAWQA QA/ QC procedures are described in Koterba and others (1995).

Field/equipment blanks consisted of three types of water, prepared to be free of organic and inorganic compounds, which were pumped through the sampling system. Field/equipment blanks were used to determine whether cleaning procedures eliminated contamination between sites and to ensure that field methods, sample shipment, and laboratory procedures had not contaminated samples. Three field/equipment blanks (for major ions, nutrients, DOC, trace metals, pesticides, and VOCs) were taken after a full cleaning and methanol/DI rinse of the equipment and sampling lines. Trip blanks consisted of vials filled with VOC-free blank water and sealed at the USGS National Water-Quality Laboratory. Trip blanks were used to verify that VOC vials were not contaminated during storage, sampling, or shipment to the laboratory. One VOC trip blank, consisting of three vials, was placed with unused VOC vials in the field vehicle used for sampling for six weeks and subsequently shipped to the laboratory with other samples. A source-solution blank was prepared by filling sample bottles directly with the blank water instead of running it through the sampling equipment. Source-solution blanks are used to check that the specially-prepared water was free of detectable concentrations of these analytes (major ions, nutrients, DOC, trace metals, VOCs, and pesticides).

Several major ions, nutrients, and trace metals, including calcium, magnesium, sodium, silica, nitrate, ammonia, phosphorus, DOC, iron, zinc, manganese, barium, chromium, aluminum, nickel, and copper were detected at low concentrations in some blank samples (table 3, in the Supplemental Information section). Detected concentrations of analytes in the blank samples were far less than those reported in ground-water samples, indicating a low likelihood of crosscontamination of ground-water samples. Low concentrations of trace metals in blanks may have been due to the stainless steel pump and stainless steel fittings in the sampling system, and the aluminum foil used to wrap the pump between samples (Menheer and Brigham, 1997), or to trace amounts of those metals in the nitric acid preservative. When groundwater samples were collected, larger volumes of water were passed through the sampling system prior to sample collection than when blanks were collected, which minimizes the concentrations of metals contributed to samples by the sampling equipment. Thirteen VOCs were detected in the field/equipment blanks, one VOC was detected in the trip blank, and 12 VOCs were detected in the source-solution blank (table 3 , in the Supplemental Information section). All but six of the concentrations of the detected VOCs were reported as estimated values, meaning that they were detected at concentrations below or near reporting limits. Three VOCs-chloroform, methylene chloride, and dichlorobromomethane-were detectable in the "VOC-free" blank water prior to its use. No pesticides were detected in any of the blank samples.

Spike samples were used to assess the recovery bias and precision/variability in recoveries of pesticides and VOCs. Extra water samples collected from three wells were spiked with known volumes of solutions containing known concentrations of selected pesticides and VOCs. Two pesticide replicate samples and three VOC replicate samples per well were spiked with the identical volumes of their respective spike solutions. In addition to spike samples, surrogates comprised of compounds similar in character to the standard analytes were added to every pesticide and VOC sample before analysis, to assess recoveries.

Pesticides analyzed on Schedule 2010 generally had mean recoveries between 75 and 120 percent except for alachlor, deethylatrazine, azinphos-methyl, benfluralin, carbaryl, carbofuran, cyanazine, $p, p$ '-DDE, 2,6-diethylanaline, ethalfluralin, linuron, malathion, methyl parathion, metolachlor, parathion, pendimenthalin, propanil, tebuthiuron, thiobencarb, and trifluralin (table 4, in the Supplemental Information section). The mean recoveries for the 2010 surrogates (diazinon- $d 10$, $\alpha-\mathrm{HCH}-\alpha 6$, and terbuthylazine) ranged from 103 to 133 percent (table 4, in the Supplemental Information section). Mean recoveries in VOC spike samples ranged from 69.3 to 115 percent (table 5, in the Supplemental Information section). Mean VOC surrogate recoveries ranged from 77.7 to 111 percent for 1,2-dichloroethane $d-4$; toluene $d-8$; and for $p$ bromofluorobenzene (table 5 , in the Supplemental Information section). Spike and surrogate recoveries for both pesticides and VOCs were generally within acceptable ranges. Concentrations of pesticides or VOCs in the environmental samples were not adjusted for surrogate recoveries.

A replicate sample is a sample collected sequentially with a regular sample-both are analyzed for the same compounds (major ions, nutrients, DOC, trace metals, radon, tritium, pesticides, and VOCs). The purpose of replicate samples is to determine the sample variability due to sample collection and laboratory analysis. Four replicate samples were analyzed for all parameters. Constituents with concentrations varying by more than five percent between the sample and replicate are listed in table 6, in the Supplemental Information section. The differences in concentrations between the sample and replicate for these constituents were $0.2 \mathrm{mg} / \mathrm{L}$ or less for nutrients and dissolved organic carbon, $3.0 \mathrm{mg} / \mathrm{L}$ or less for major ions and trace metals, $0.001 \mu \mathrm{g} / \mathrm{L}$ or less for pesticides, and $0.1 \mu \mathrm{g} / \mathrm{L}$ or less for VOCs, 
and 50 picoCuries per Liter $(\mathrm{pCi} / \mathrm{L})$ or less for radon (table 6 , in the Supplemental Information section).

Summaries of water-quality data in this report include tables of median values, standard deviations, ranges of values, boxplots of selected-water quality constituents, statistical analyses of differences in water quality between confined and unconfined settings and between the PDC and JDN portions of the aquifer, and diagrams of major-ion composition. The nonparametric MannWhitney test (MW test) and the two sample t-test ( $t$-test) were used to test for differences between groups. Censored values were set equal to zero. A confidence level of 95 percent was used to indicate statistically significant differences.

\section{Acknowledgments}

The authors thank the private well owners who volunteered their wells for sampling. Paul Hanson of the USGS prepared maps and illustrations. Jack Bates and Nadene Cable of the Wisconsin Department of Natural Resources assisted in locating suitable wells for sampling in Wisconsin. The authors also thank Rick Lindgren and David Saad of the USGS, Roman Kanivetsky and Tony Runkel of the Minnesota Geological Survey, Tom Clark of the Minnesota Pollution Control Agency, and Jim Walsh of the Minnesota Department of Health for reviewing this report.

\section{Ground-Water Quality}

Chemical analyses described in this report include physical parameters, major ions, nutrients, DOC, trace metals, radon, tritium, pesticides, and VOCs. Results of these analyses are described in this section of the report. Data are available from the USGS office in Mounds View, Minnesota.

\section{Physical Parameters}

Physical parameters are summarized in table 1, in the Supplemental Information section. Median depths to water were 83.5 and $28.0 \mathrm{ft}$ below land surface in confined and unconfined wells, respectively. The $\mathrm{pH}$ 's were alkaline, ranging between 7.1 and 8.1 (table 1, in the Supplemental Information section, fig. 6), due to buffering by carbonates in the aquifer. Specific conductances and alkalinities were relatively high (mostly due to dissolution of dolomite), with medians of 560 and 482 microsiemens per centimeter for specific conductances and 267 and $216 \mathrm{mg} / \mathrm{L}$ as $\mathrm{CaCO}_{3}$ for alkalinities, in confined and unconfined portions of the PDCJ aquifer, respectively (table 1, in the Supplemental Information section, fig. 6). Specific conductances and alkalinities were greater (the difference was statistically significant at a 95 percent confidence level (t-test)) in water in the confined portion of the aquifer. Dissolved oxygen concentrations in water from the wells ranged from less than 0.1 to $11.5 \mathrm{mg} / \mathrm{L}$ and tended to be greater in water samples from the unconfined portion of the PDCJ aquifer, although the differences were not statistically significant at a 95 percent confidence level ( $t-$ test). Approximately half the dissolved oxygen concentrations were less than 1 $\mathrm{mg} / \mathrm{L}$ (table 1 , in the Supplemental Information section, fig. 6), indicating that reduction processes such as denitrification and sulfate reduction occur in ground water in the vicinity of some of the wells in the unconfined portion of the aquifer. Water levels between confined and unconfined portions of the aquifer were statistically different at the 95 percent confidence level ( $t$-test); shallower water levels were measured in wells completed in the unconfined portion of the aquifer.

\section{Major lons}

Major ions analyzed in water samples included calcium, magnesium, sodium, potassium, chloride, sulfate, fluoride, bromide, and silica (fig. 7). All samples were calcium-magnesium-bicarbonate type waters (fig. 8). Major-ion compositions of samples from this study are similar to those of Nemetz (1993), and are similar to the calcium-magnesium-bicarbonate type water described by Wall and Regan (1994) and Smith and Nemetz (1996) for the aquifer. Hardness, a water-quality variable important to most water users, was calculated from the concentrations of calcium and magnesium in the water samples.
Calcium concentrations in water samples were greater than those of the other major ions (table 7, in the Supplemental Information section, fig. 7). Calcium, which occurs only in the divalent $\left(\mathrm{Ca}^{+2}\right)$ oxidation state, occurs in ground water primarily through dissolution of the relatively soluble carbonate minerals calcite and dolomite, and secondarily through dissolution of the silicate minerals feldspar, pyroxene, and amphibole.

Dissolution of dolomite $\left((\mathrm{Ca}, \mathrm{Mg}) \mathrm{CO}_{3}\right)$ in the PDC portion of the aquifer is the most likely source of much of the calcium, magnesium, and alkalinity in water samples from most of the wells. Rainfall is a minor source of calcium and other major ions including magnesium, sodium, potassium, chloride, and sulfate through entrainment of terrestrial dust in the atmosphere. Concentrations of these ions in rainfall in the study area are typically less than $1.0 \mathrm{mg} / \mathrm{L}$ from samples in the upper Midwest in 1995 (National Acidic Deposition Program/National Trends Network, electronic commun., 1997). Calcium concentrations were slightly greater (but not at the 95 percent confidence level (t-test)) in water samples from the confined portion of the PDCJ aquifer, which may be a function of longer residence times and thus greater opportunity for dolomite dissolution.

Magnesium concentrations were generally less, by a factor of two to three, than calcium concentrations (table 7 , in the Supplemental Information section, fig. 7). Magnesium, like calcium, is a major ion which contributes to hardness of water. Hardness, an indicator of the ability of water to form insoluble residues with soaps and to form scale in boilers and pipes, is calculated by multiplying the sum of milliequivalents per liter of calcium and magnesium by 50 , and is expressed in $\mathrm{mg} / \mathrm{L}$ of $\mathrm{CaCO}_{3}$ (Hem, 1985). By the hardness scale of Durfor and Becker (1964), most of the water samples were "very hard" (greater than $180 \mathrm{mg} / \mathrm{L}$ as $\mathrm{CaCO}_{3}$ ). The water in the confined portion of the PDCJ aquifer was significantly harder, at the 95 percent confidence level ( $t$-test), than water in the unconfined portion of the PDCJ aquifer (table 7 , in the Supplemental Information section). As with calcium, 

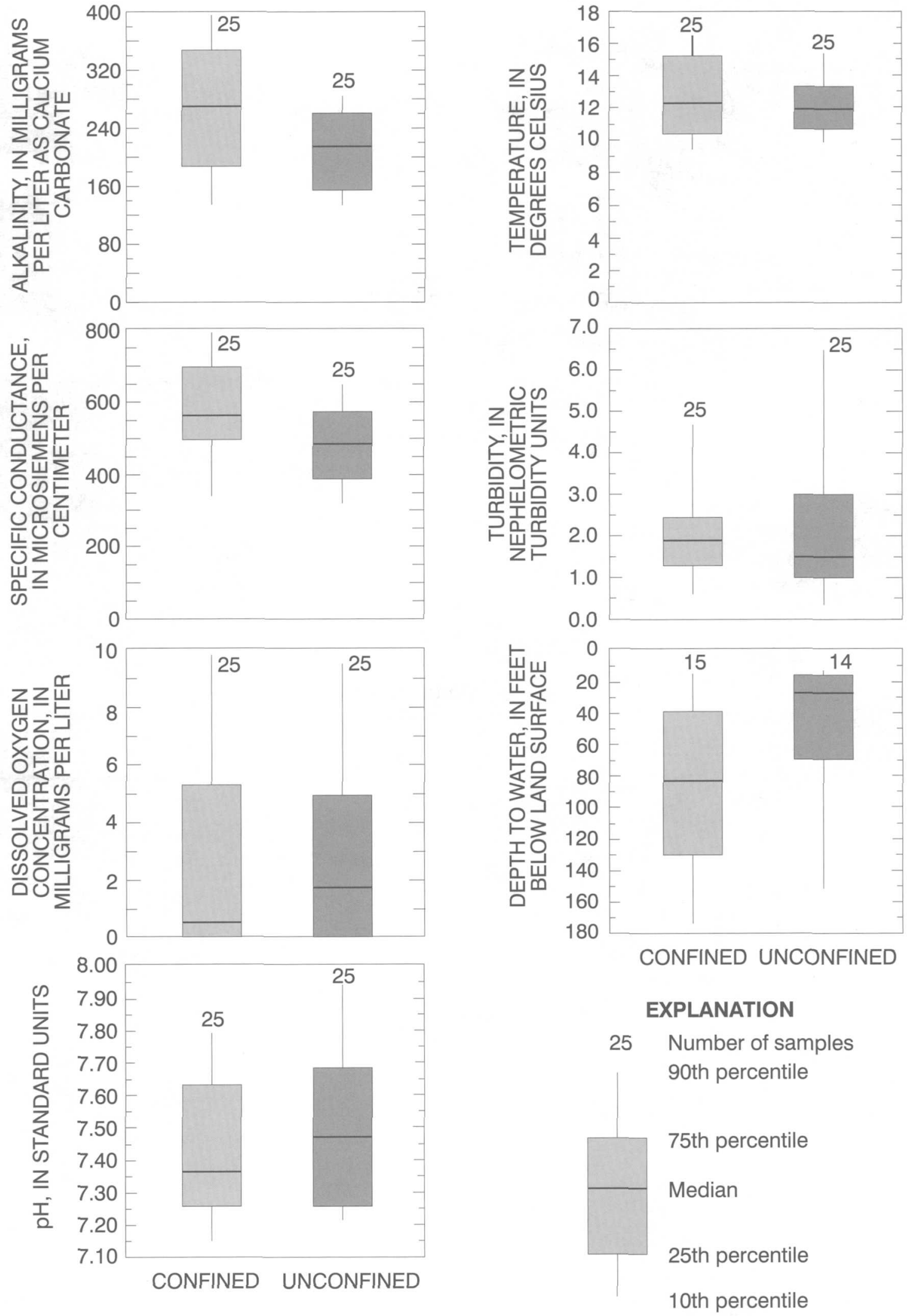

Figure 6.--Field measurements of physical parameters in water samples from Prairie du Chien-Jordan aquifer study area wells. 


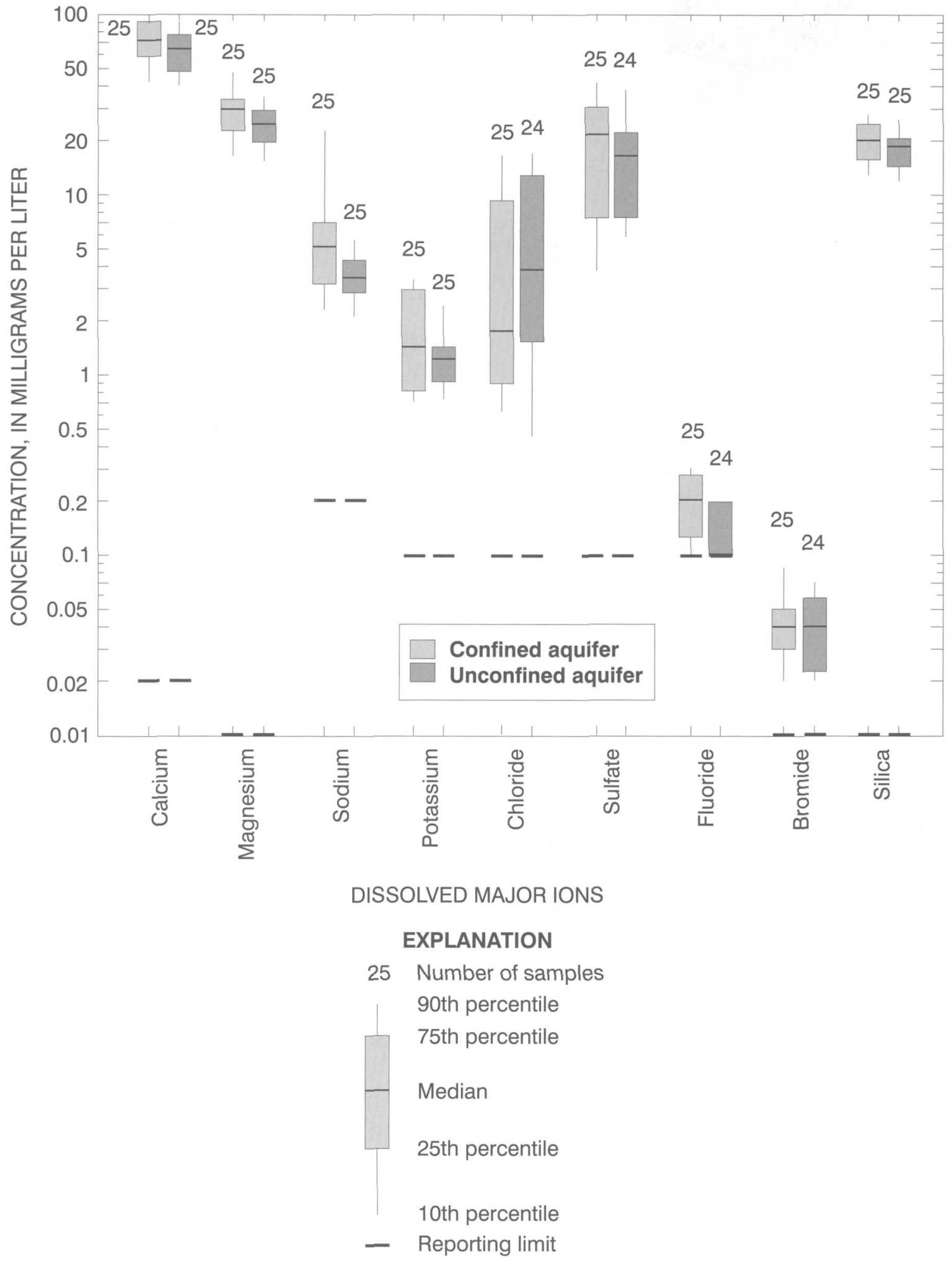

Figure 7.--Concentrations of dissolved major ions in water samples from Prairie du Chien-Jordan aquifer study area wells. 


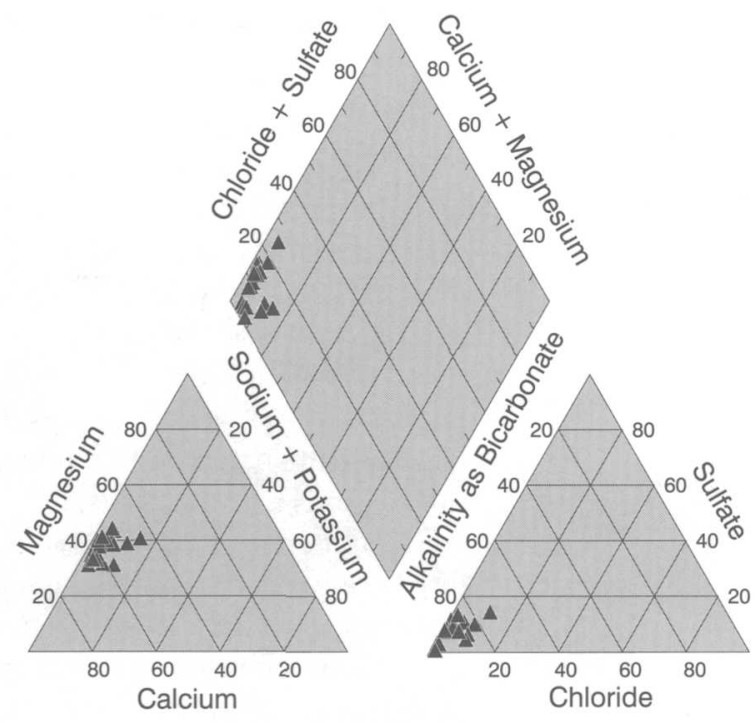

PERCENT MILLIEQUIVALENTS PER LITER

Confined Prairie du Chien-Jordan aquifer

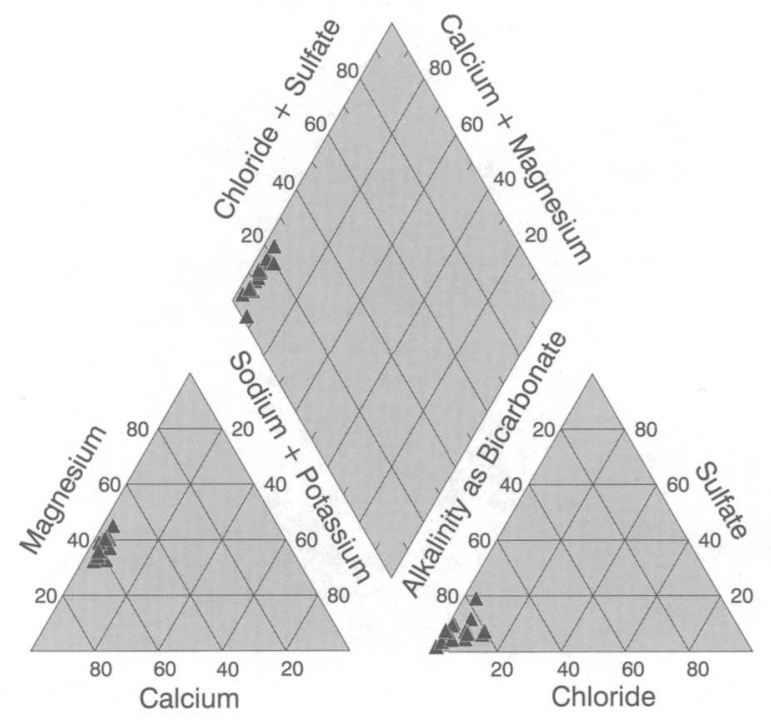

PERCENT MILLIEQUIVALENTS PER LITER

Unconfined Prairie du Chien-Jordan aquifer

Figure 8.--Major ion composition of water samples from Prairie du Chien-Jordan aquifer study area wells.

the primary source of magnesium in the PDCJ aquifer is probably from the dissolution of dolomite. Magnesium concentrations were greater, at the 95 percent confidence level ( $\mathrm{t}$-test), in water from the confined portion of the PDCJ aquifer (table 7, in the Supplemental Information section).

Sodium concentrations were generally less than $10 \mathrm{mg} / \mathrm{L}$ (table 7 , in the Supplemental Information section, fig. 7). Significantly greater sodium concentrations, at the 95 percent confidence level (MW-test), in the confined portion of the PDCJ aquifer may again be due to longer residence times allowing longer contact with and dissolution of sodiumcontaining minerals such as feldspars.

Potassium concentrations were less than sodium concentrations by a factor of about three (table 7, in the Supplemental Information section, fig. 7). Potassium is applied as a component of fertilizers and is a common constituent in igneous and sedimentary rocks, primarily as grains or particles of feldspars and micas. Potassium is generally present in concentrations less than sodium in natural waters because potassium is more likely to be incorporated into clay mineral structures and is also an essential nutrient absorbed by plants (Hem, 1985). Potassium concentrations were generally greater, but not at the 95 percent confi- dence level (t-test), in water from the confined portion of the PDCJ aquifer, probably due to greater residence times and opportunity for dissolution of potassium-containing feldspars.

Chloride concentrations ranged from 0.2 to $25 \mathrm{mg} / \mathrm{L}$ in water samples, with slightly greater concentrations in water from the unconfined portion of the PDCJ aquifer (table 7, in the Supplemental Information section, fig. 7), but not at the 95 percent confidence level (MW-test). Probable sources of anthropogenic chloride in ground-water samples include sodium chloride applied to de-ice highways in the winter and potassium chloride $(\mathrm{KCl})$ fertilizers applied to cropland and lawns during the summer.

Sulfate concentrations were greater than chloride, sodium, and potassium concentrations, generally ranging from 0.4 to $56 \mathrm{mg} / \mathrm{L}$ (table 7 , in the Supplemental Information section, fig. 7).

Sulfate $\left(\mathrm{SO}_{4}{ }^{-2}\right)$ is the most common form of sulfur dissolved in oxygenated natural waters (Hem, 1985). In anoxic systems, bacteria strip off oxygen from sulfate anions, converting them to the relatively toxic hydrogen sulfide $\left(\mathrm{H}_{2} \mathrm{~S}\right)$ gas. Sulfur is widely distributed, in reduced form, as metallic sulfide minerals in igneous and sedimentary rocks and as sulfate in the mineral gypsum (Hem, 1985). Other sig- nificant sources of sulfur include atmospheric emissions from volcanoes, combustion of fossil fuels, and smelting of ores (Hem, 1985). Greater sulfate concentrations (but not at the 95 percent confidence level (MW test)) and lesser dissolved oxygen concentrations in water in the confined portion of the PDCJ aquifer indicate that oxidation of sulfide minerals may be a primary source of the sulfate in the PDCJ aquifer.

Concentrations of fluoride were less than $0.5 \mathrm{mg} / \mathrm{L}$ (table 7 , in the Supplemental Information section, fig. 7). Fluoride in ground water may be derived from dissolution of minerals such as fluorite, fluoroapatite, amphiboles, micas, and feldspars in sedimentary rocks.

Bromide concentrations were less than $0.2 \mathrm{mg} / \mathrm{L}$ (table 7 , in the Supplemental Information section, fig. 7). Bromide is similar in chemical behavior to chloride, but is much less abundant in natural waters (Hem, 1985). In addition to naturally occurring bromide, bromide may also be derived from ethylene dibromide, a widely-used gasoline additive and grain fumigant (Verschueren, 1983).

Silica concentrations ranged from 9.5 to $30 \mathrm{mg} / \mathrm{L}$ (table 7 , in the Supplemental Information section, fig. 7). Silicon is the second-most abundant element in the earth's crust, exceeded only by oxygen 
(Hem, 1985). Silicon forms strong bonds with oxygen, commonly forming $\mathrm{SiO}_{4}{ }^{-4}$ tetrahedra as building blocks of many igneous and metamorphic minerals. $\mathrm{SiO}_{2}$, the mineral quartz, is an important constituent in igneous rocks and sandstones. Silica concentrations were generally greater in wells completed in the confined portion of the PDCJ aquifer (fig. 7), but not at the 95 percent confidence level (t-test), probably indicating that silica progressively dissolves with greater residence times in the aquifer.

\section{Nutrients and Dissolved Organic Carbon}

The primary nutrients of concern in ground water are nitrate and phosphorus. Nitrate is typically reported as the sum of nitrite plus nitrate as nitrogen $\left(\mathrm{NO}_{2}{ }^{-}+\right.$ $\mathrm{NO}_{3}{ }^{-}$as $\mathrm{N}$ ). Because nitrite is usually detected in low concentrations, nitrite plus nitrate will be referred to as "nitrate" in this report. Elevated concentrations of nitrate in drinking water (exceeding the USEPA MCL of $10 \mathrm{mg} / \mathrm{L}$ as nitrogen) (U.S. Environmental Protection Agency, written commun., 1998) have been associated with "blue-baby" syndrome (methemoglobinemia), and with increased rates of stomach cancer, birth defects, miscarriage, and leukemia (Forman and others, 1985; Dorsch and others, 1984; Fan and others, 1987; National Research Council, 1985). Nitrate and phosphorus discharged to surface water can also lead to eutrophication, which depletes oxygen in lakes and rivers, leading to increased mortality of oxygen- and temperature-sensitive native aquatic species.

Nitrate in ground water is principally derived from the following sources: natural mineral deposits (which do not occur in the study area), animal wastes, soils, and fertilizers. Most nitrate results from oxidation (nitrification) in soils of the ammonia form of nitrogen (principally $\mathrm{NH}_{4}{ }^{+}$), which leaches from animal wastes, soils, and fertilizers. Nitrate concentrations in rainfall in the upper Midwest ranged from 1.0 to $1.5 \mathrm{mg} / \mathrm{L}$ in 1995 (National Acidic Deposition Program/National Trends Network, electronic commun., 1997). Nitrate concentrations exceeding $3 \mathrm{mg} / \mathrm{L}$ commonly indicate contamination by non-natural sources (Madison and Brunett, 1984). Most nitrate concentrations in water samples collected for this study were less than $3 \mathrm{mg} / \mathrm{L}$ (table 8 , in the Supplemental Information section, fig. 9), but the MCL for nitrate $(10 \mathrm{mg} / \mathrm{L})$ was exceeded in two water samples from the unconfined portion of the PDCJ aquifer and no samples exceeded the MCL in the confined portion of the PDCJ aquifer. Nitrate was detected (at or above the reporting limit) in 67 percent of water samples from wells in the confined portion of the PDCJ and 84 percent of water samples from wells in the unconfined portion of the PDCJ. Nitrate concentrations were generally greater in the unconfined portion of the PDCJ aquifer than from wells in the confined portion (table 8 , in the Supplemental Information section, figs. 9, 10); however, the difference was not statistically significant at the 95 percent confidence level (MW-test). Nitrate concentrations exceeded the USEPA MCL in samples from two wells in agricultural and urban areas where the aquifer is exposed at the land surface or where it underlies thin deposits of outwash in western Wisconsin and southeastern Minnesota.

Nitrate can be removed from water by the processes of denitrification and assimilation. Denitrification, which reduces nitrate to gases such as nitrous oxide $\left(\mathrm{N}_{2} \mathrm{O}\right)$ or dinitrogen $\left(\mathrm{N}_{2}\right)$, is accomplished by bacteria or reduced forms of metals in oxygen-depleted water. Assimilation is the uptake of nitrate and other nutrients by plant roots or by biota such as algae and bacteria, and generally is limited to the soil zone.

Nitrite $\left(\mathrm{NO}_{2}{ }^{-}\right)$is an unstable intermediate product of nitrification which does not commonly occur in substantial concentrations in ground water (Wall and others, 1991) (table 8, in the Supplemental Information section, fig. 9). Because organic nitrogen and ammonia nitrogen tend to sorb to organic matter or to clay particles, concentrations of these constituents dissolved in the water were relatively low or non-detected (table 8 , in the Supplemental Information section, fig. 9).

Phosphorus concentrations in groundwater samples ranged from less than 0.01 to $0.07 \mathrm{mg} / \mathrm{L}$ (table 8, in the Supplemental Information section, fig. 9).

Phosphorus tends to be taken up by plants, and is also sorbed to organic matter or to metallic oxides in soils and in the unsaturated and saturated zones. Because of sorption to organic and inorganic fractions in soils and sediments, phosphorus concentrations in ground water are commonly several orders of magnitude less than nitrate concentrations. Sources of phosphorus include minerals in igneous and sedimentary rocks, animal wastes, and detergents containing phosphorus (Hem, 1985). Orthophosphate $\left(\mathrm{PO}_{4}{ }^{-3}\right)$, the final dissociation product of phosphoric $\left(\mathrm{H}_{3} \mathrm{PO}_{4}\right)$ acid, is one of many chemical forms in which phosphorus occurs in natural waters. Orthophosphate is a form of phosphorus preferentially taken up by plants and algae. Orthophosphate concentrations generally were equal to phosphorus concentrations, indicating that orthophosphate is the primary form of phosphorus dissolved in water in the PDCJ aquifer.

Dissolved organic carbon, resulting from DOC in rainfall and from the dissolution of organic material in soils and rock by percolating water and by ground water, was detected in water samples from all of the wells, generally in concentrations less than $1 \mathrm{mg} / \mathrm{L}$ (table 8 , in the Supplemental Information section, fig. 9). Although not a nutrient, DOC concentrations in water can affect dissolved oxygen concentrations, causing changes in redox conditions, which can affect nutrient concentrations.

\section{Trace Metals}

Trace metals analyzed in water samples are listed in table 9, in the Supplemental Information section. Although they are semi-metallic elements, arsenic, selenium, and antimony are referred to as trace metals in this report. Chemical conditions are often the controlling factor in observed concentrations of these elements in ground water as compared to the element's availability, as 


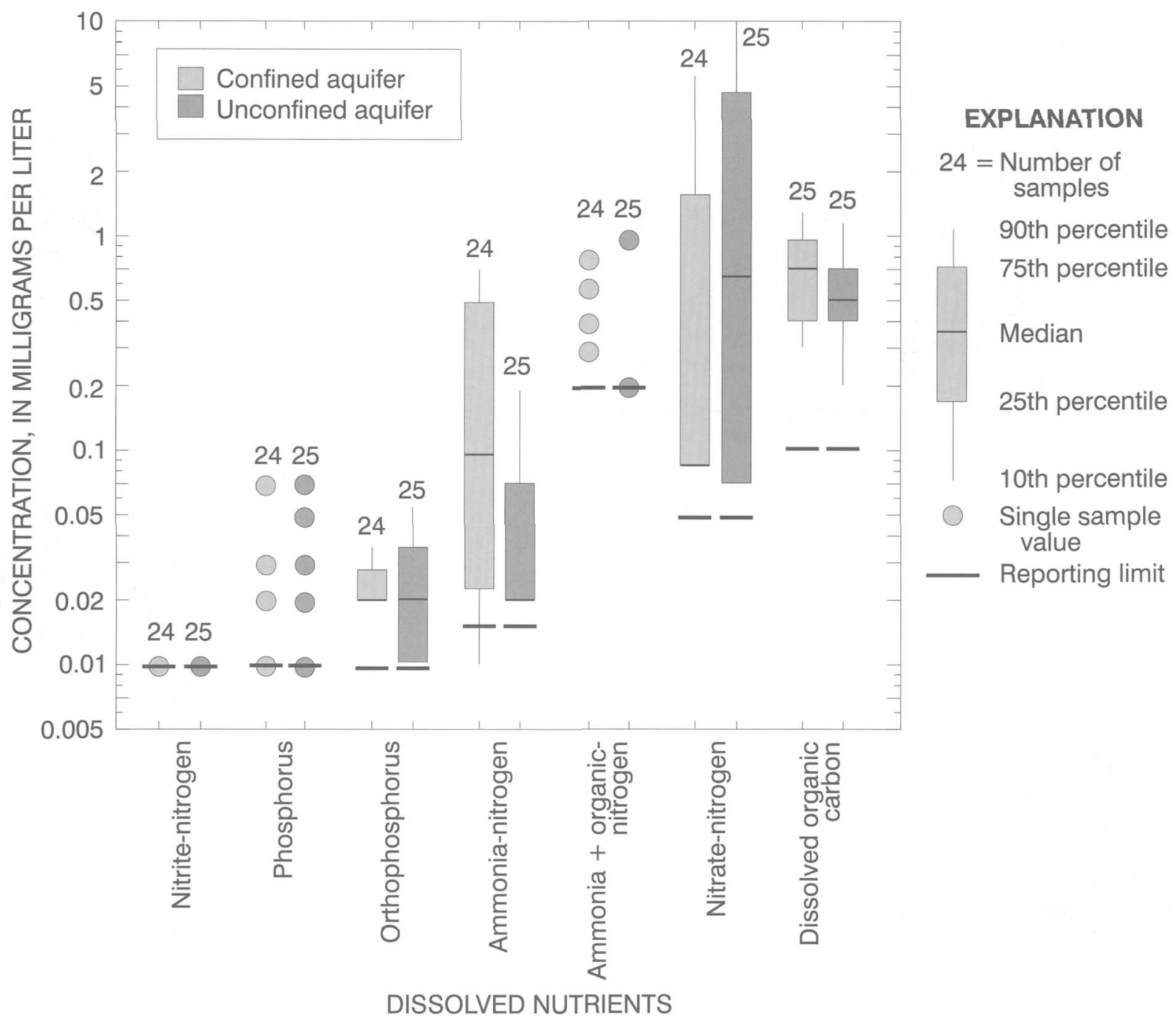

Figure 9.--Concentrations of dissolved nutrients and dissolved organic carbon in water samples from Prairie du Chien-Jordan aquifer study area wells.

suggested by the average abundance in rocks (Hem, 1985).

Iron was detected in the greatest concentrations of any of the trace metals (table 9, in the Supplemental Information section, fig. 11). Potential sources of iron in ground water include minerals common in bedrock or glacial deposits in the study area-pyroxenes, amphiboles, biotite, magnetite, olivine, ferrous polysulfides, siderite, and ferric oxides or oxyhydroxide minerals (Hem, 1985). Iron is also present in organic wastes and in decaying plant debris and humic compounds in soils (Hem, 1985). Iron tends to be dissolved in ground water as the ferrous ion $\left(\mathrm{Fe}^{+2}\right)$, which is typically released to ground water through the oxidation of ferrous sulfides such as pyrite, or through the reduction of ferric hydroxides (Hem, 1985). Oxygen in ground water can oxidize ferrous iron to the ferric ion $\left(\mathrm{Fe}^{+3}\right)$, which forms relatively insoluble ferric hydroxides (Hem, 1985). Lesser dissolved oxygen concentrations in the confined portion of the PDCJ aquifer inhibit formation of iron hydroxides, causing greater dissolved iron concentrations in those portions of the aquifer (although not statistically significant at the 95 percent confidence level (MWtest)) (table 9, in the Supplemental Information section). Because iron hydroxide compounds stain laundry and plumbing fixtures, the USEPA has established a SMCL for iron of $0.3 \mathrm{mg} / \mathrm{L}(300 \mu \mathrm{g} / \mathrm{L})$ (U.S. Environmental Protection Agency, 1996). Thirty-seven percent of all water samples exceeded the USEPA SMCL46 percent of water samples from the confined portion and 28 percent from the unconfined portion.

Concentrations of zinc ranged from 3 to $659 \mu \mathrm{g} / \mathrm{L}$ (table 9 , in the Supplemental Information section, fig. 11). The concentrations of zinc above background levels (generally less than $10 \mu \mathrm{g} / \mathrm{L}$ ) (Hem, 1985) may be due to the use of galvanized piping in the domestic well systems. None of the zinc concentrations exceeded the USEPA SMCL for zinc $(5,000 \mu \mathrm{g} / \mathrm{L}$ (table 9 , in the Supplemental Information section)).

Manganese concentrations ranged from less than 1 to $1,040 \mu \mathrm{g} / \mathrm{L}$ (table 9 , in the Supplemental Information section, fig. 11). Because of the tendency for 


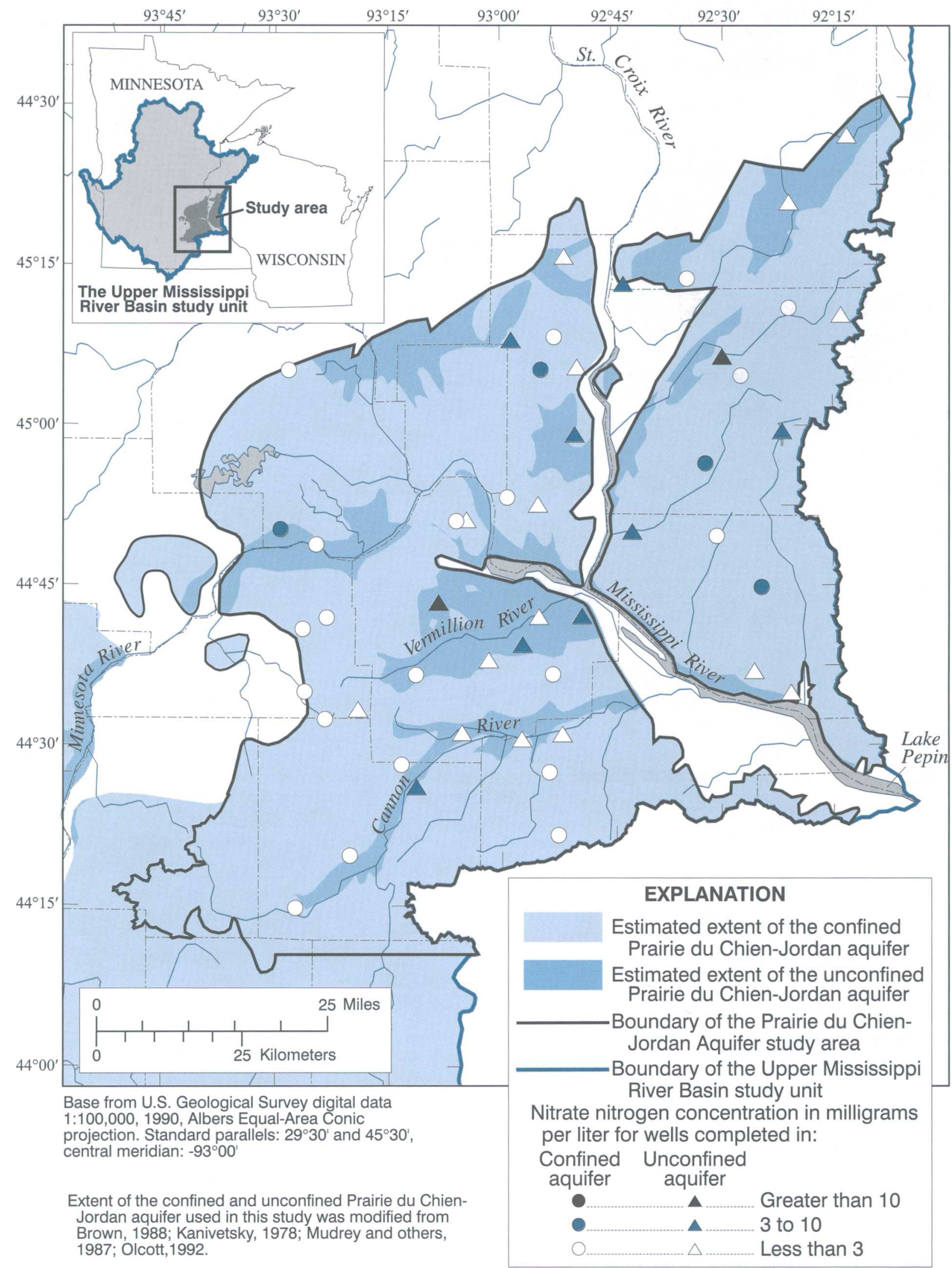

Figure 10.--Locations of wells and nitrate concentrations in water samples from wells completed in the Prairie du Chien-Jordan aquifer 


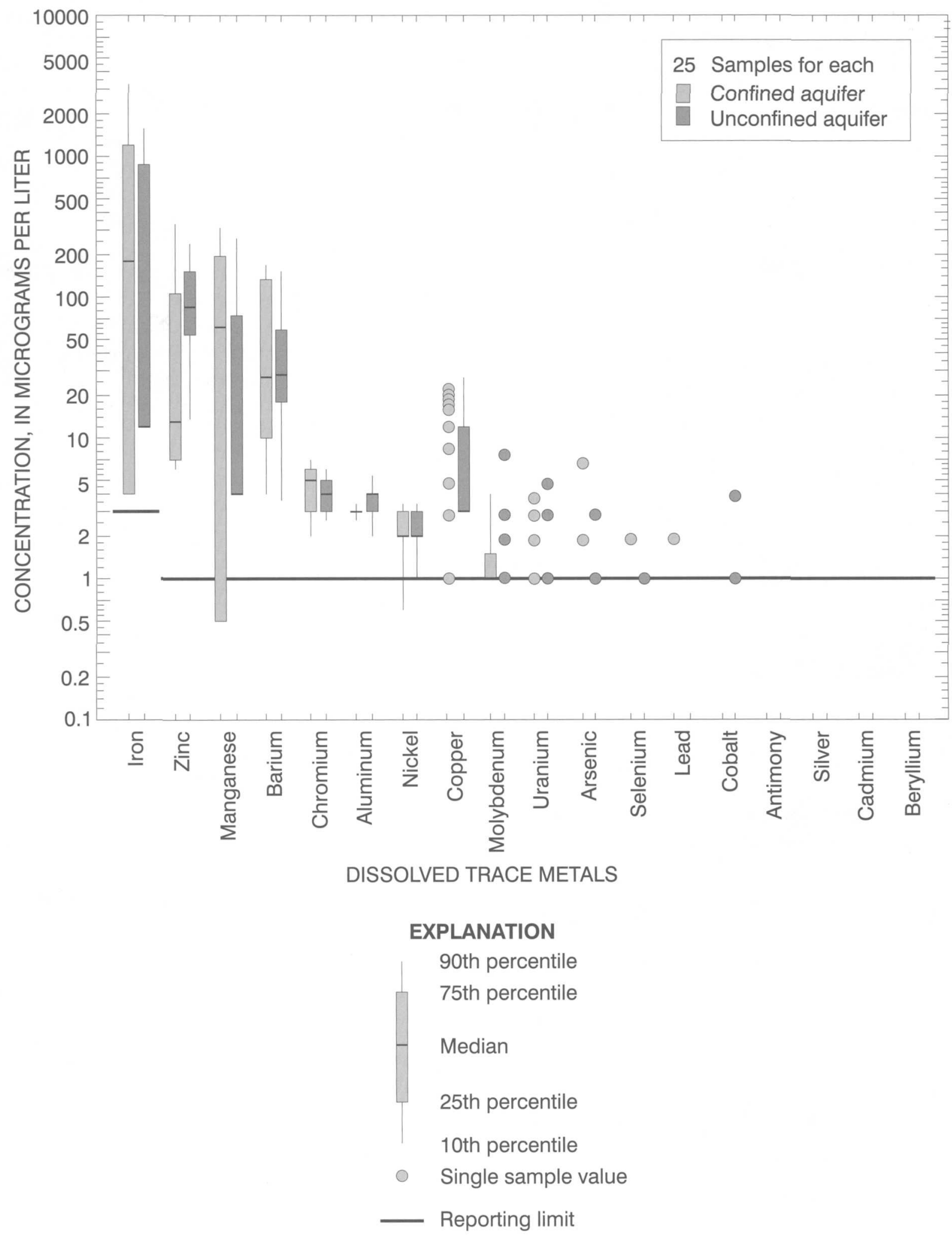

Figure 11.--Concentrations of trace metals in water samples from Prairie du Chien-Jordan aquifer study area wells. 
black manganese oxide stains to form on laundry and plumbing fixtures, the USEPA has set a SMCL of $50 \mu \mathrm{g} / \mathrm{L}$ for manganese (U.S. Environmental Protection Agency, 1996). Water samples from 42 percent of the wells had manganese concentrations exceeding the USEPA SMCL-52 percent of water samples from wells in the confined PDCJ and 32 percent from wells in the unconfined PDCJ. Manganese redox-driven reactions are similar to those that occur with iron, but manganese is somewhat less likely to precipitate in hydroxide complexes (Hem, 1985). Manganese is a minor constituent in igneous rocks such as olivine, pyroxenes, and amphiboles and small amounts of manganese (Hem, 1985) commonly substitute for calcium in limestones and dolomites. As with iron, manganese concentrations tended to be greater (but not at the 95 percent confidence level (MW test)) in the more reducing, confined portion of the PDCJ aquifer.

Barium concentrations ranged from 1 to $329 \mu \mathrm{g} / \mathrm{L}$ in water samples (table 9 , in the Supplemental Information section, fig. 11). Barium is contained in the relatively insoluble sulfate mineral barite $\left(\mathrm{BaSO}_{4}\right)$, and is also a common constituent in metallic oxides and hydroxides (Hem, 1985). The USEPA drinking-water MCL for barium of $2 \mathrm{mg} / \mathrm{L}$ (U.S. Environmental Protection Agency, 1996) was not exceeded in any of the water samples.

The trace metals chromium, aluminum, nickel, copper, and molybdenum were detected in water samples from most of the wells, generally at concentrations less than $10 \mu \mathrm{g} / \mathrm{L}$ (table 9, in the Supplemental Information section, fig. 11). Those metals may be partly attributed to galvanized steel well casings and water-supply pipes in the domestic well systems, stainless steel fittings in the water-sampling system, or the aluminum foil used to wrap the pump after each cleaning. None of the detected concentrations of these metals exceeded the respective USEPA MCLs (U.S. Environmental Protection Agency, 1996).

Water samples from less than onethird of the wells had detectable concentrations of the trace metals uranium, arsenic, selenium, lead, cobalt, anti- mony, silver, cadmium, or beryllium (table 9, in the Supplemental Information section, fig. 11). Concentrations of these trace metals were generally less than 5 $\mu \mathrm{g} / \mathrm{L}$. With the exception of lead, none of the detected concentrations of these trace metals exceeded MCLs or SMCLs established by the USEPA (1996). Lead was detected in water samples from three wells in the confined PDCJ (all at concentrations of $2.0 \mu \mathrm{g} / \mathrm{L})$.

\section{Radon}

Radon gas $\left({ }^{222} \mathrm{Rn}\right)$ is a radioactive noble gas created by the decay of radium isotopes 223, 224, and 226 (Hem, 1985). The source of radon gas in ground water is the radioactive decay of naturally occurring uranium in sediments and bedrock. Radon is soluble in water and readily volatilizes. Radon has a half-life of 3.8 days and decays to ${ }^{210} \mathrm{~Pb}$ by emitting three alpha particles through a series of short-lived daughter isotopes (Hem, 1985). Ingestion of radon directly in drinking water probably does not pose a serious health risk (Aieta and others, 1987; Cothern, 1987; Crawford-Brown, 1990). The primary risk posed by radon is due to de-gassing into household air (Wanty and Nordstrom, 1993). Radon can be absorbed by lung tissues and alpha particles emitted during decay can cause damage to tissue. Prolonged respiration of high concentrations of radon gas have been linked to lung cancer (National Research Council, 1988). Because of this risk, the USEPA proposed an MCL of $300 \mathrm{pCi} / \mathrm{L}$ for drinking water. However, the MCL for radon was withdrawn in August 1996 as part of the reauthorization of the Clean Water Act, and is currently being reevaluated by the National Science Foundation (Safe Drinking Water Hotline, oral commun., 1997).

Radon concentrations in water samples ranged from about 100 to $1,000 \mathrm{pCi} /$ L (figs. 12 and 13), similar to results of other ground water studies (Wanty and Nordstrom, 1993). The median radon concentration was $500 \mathrm{pCi} / \mathrm{L}$ from wells completed in the confined portion of the PDCJ aquifer and $340 \mathrm{pCi} / \mathrm{L}$ from wells completed in the unconfined portion of the PDCJ aquifer. Sixty-six percent of water samples (64 percent of water samples from wells completed in the confined portion and 68 percent of water samples from wells completed in the unconfined portion) had radon concentrations that exceeded the withdrawn MCL. Radon concentrations in water samples from the confined and unconfined portions of the PDCJ aquifer were not significantly different at the 95 percent confidence level (t-test).

\section{Tritium}

Tritium $\left({ }^{3} \mathrm{H}\right)$, a radioactive hydrogen isotope, may replace normal hydrogen in water molecules and breaks down to helium $\left(\mathrm{He}^{3}\right)$ through emission of a $\beta$ (beta) particle and a neutrino. Tritium, with a half-life of 12.43 years, is naturally produced in the atmosphere by reactions between nitrogen and oxygen. Anthropogenic sources of tritium include

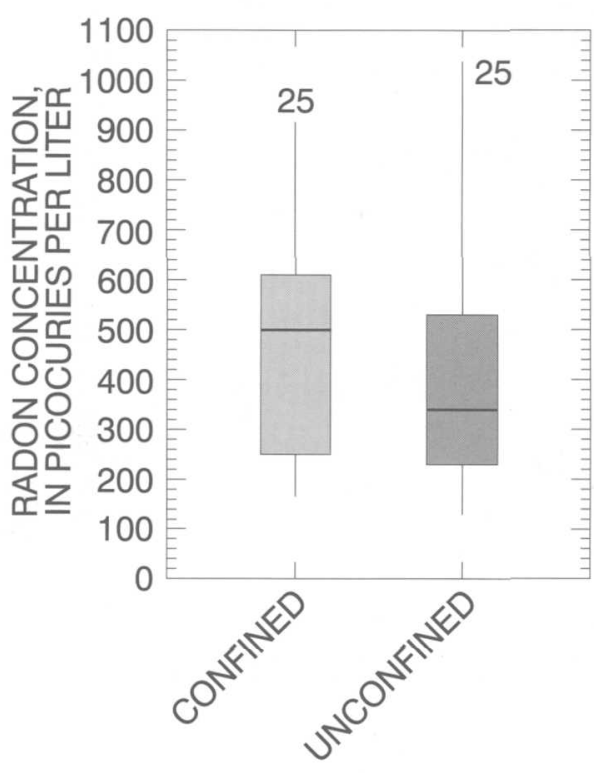

\section{EXPLANATION}

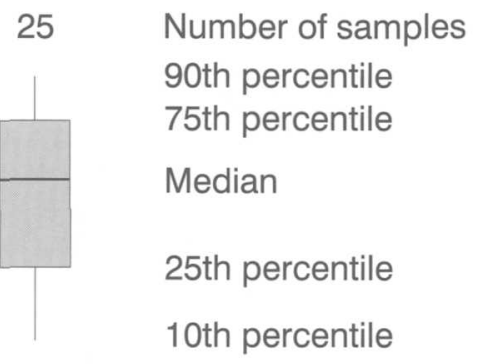
Figure 12.--Concentrations of radon in water samples from Prairie du Chien-Jordan aquifer study area wells.




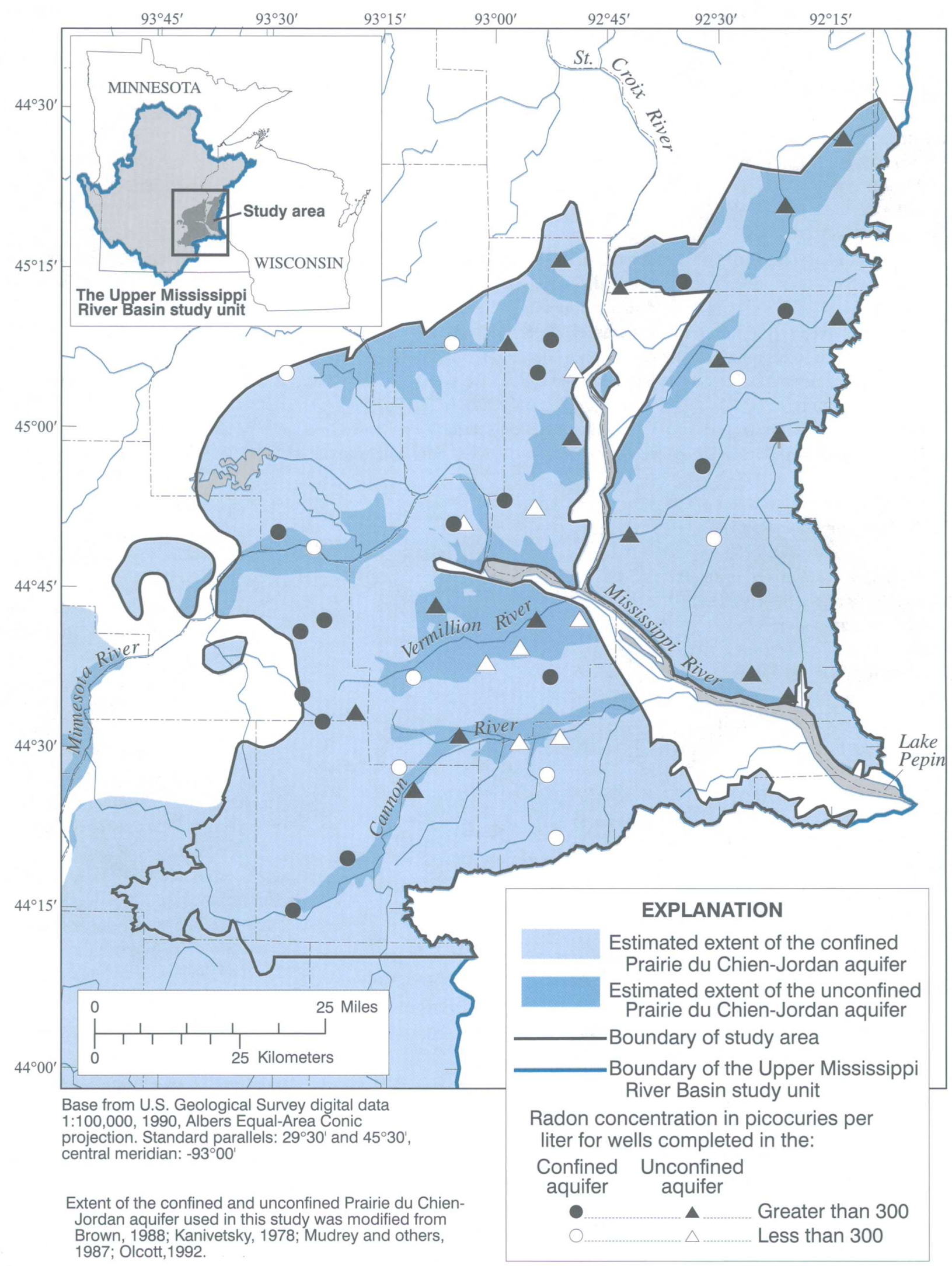

Figure 13.--Locations of wells and radon concentrations in water samples from wells completed in the Prairie du Chien-Jordan aquifer. 
nuclear reactors and detonations of fusion or thermonuclear weapons. Prior to the advent of atmospheric testing of fusion bombs in 1953, tritium concentrations in rainwater were approximately 2-8 tritium units $(1$ tritium unit $(\mathrm{TU})=1$ tritium atom $/ 10^{18}$ hydrogen atoms) (Drever, 1988). During the 1960 's, at the maximum of atmospheric weapons testing, tritium concentrations in rainwater increased to over 5,000 TU (Plummer and others, 1993). Because of its short half-life and lack of atmospheric weapons testing since the 1960 's, tritium concentrations in rainfall are gradually decreasing to "pre-1953" levels. Because tritium produced by atmospheric testing of fusion bombs is dissolved in ground water, it is useful in determining relative ground-water ages (Alexander and Alexander, 1989). Current tritium concentrations in rainwater range from 520 TU (Jim Walsh, Minnesota Department of Health, oral commun., 1998). Tritium concentrations in ground water of less than $0.8 \mathrm{TU}$ probably indicate that the water was recharged prior to 1953 ; 0.8-10 TU probably indicate mixed priorand post-1953 water; greater than $10 \mathrm{TU}$ probably indicate recharge after 1953 (Alexander and Alexander, 1989). As tritium becomes less useful as an age-dating tool, it is being replaced by other age-dating constituents such as carbon-14 and chlorofluorocarbons.

Water samples from 25 wells were analyzed for tritium concentrations to evaluate whether water in the PDCJ aquifer has been recharged since 1953, and to evaluate whether water in the confined portion of the aquifer is older than water in the unconfined portion of the aquifer (figs. 14 and 15). Tritium concentrations in the water samples from the confined portion of the PDCJ aquifer ranged from less than 0.3 to 26.9 TU's (median=1.9), and tritium concentrations from the unconfined portion of the PDCJ aquifer ranged from less than 0.3 to 29.4 TU's (median=6.9), probably indicating that the water in the unconfined portion of the aquifer tends to be slightly younger than water in the confined portion of the aquifer. Similar ranges in tritium concentrations were found by Wall and Regan (1994). The differences in tritium concentrations between confined and unconfined portions were not statistically significant at the 95 percent confidence level (MW test). Both median concentrations are in the range of mixed water, and therefore probably include both pre-1953 and post-1953 water recharge dates (Alexander and Alexander, 1989).

\section{Pesticides}

Pesticides are compounds used to kill plant or insect pests. They are applied primarily to cropland in rural areas, but also for lawns, rights-of-way, and gardens in urban areas. A total of 47 pesticide compounds (parent and breakdown products), including several different classes of pesticides such as triazines, organophosphorus, organochlorines, carbamates, and others, were analyzed in water samples (table 10, in the Supplemental Information section). Pesticides may also be volatilized during and after

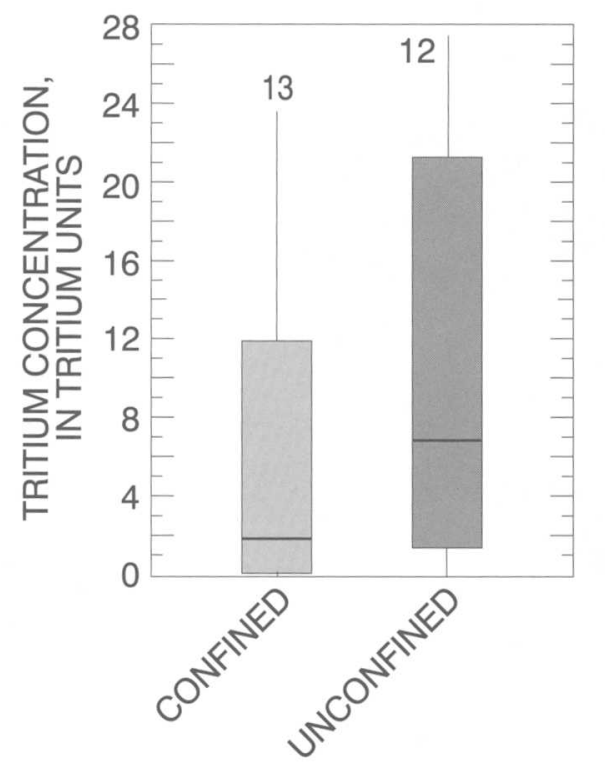

\section{EXPLANATION}

13 Number of samples

90th percentile

75th percentile

Median

25th percentile

10th percentile

Figure 14.--Concentrations of tritium in water samples from Prairie du Chien-Jordan aquifer study area wells. application and deposited at the land surface by atmospheric deposition over great distances (Spencer and Cliath, 1990; Majewski and Capel, 1995). Most pesticides are designed to stay in the soil zone. Many are prone to sorb to solids and organic matter in soils, are degraded by abiotic and biotic processes in the unsaturated zone, and have relatively low solubilities in water (Rao and Alley, 1993). One or more pesticides were detected in 36 percent of water samples from wells in the confined PDCJ and 60 percent of water samples from wells in the unconfined PDCJ (fig. 16). Differences in the frequency of pesticide detections between the two groups were not statistically significant at the 95 percent confidence level (MW test). Most of the wells with detections of pesticides tend to be in the eastern portion of the study area where the aquifer is closer to land surface and where glacial till confining units are less extensive.

Atrazine and its metabolite (breakdown product) deethylatrazine were the most commonly-detected pesticide compounds in water samples (fig. 17). Atrazine was detected in water samples from 36 percent of wells in the confined PDCJ and 52 percent of wells in the unconfined PDCJ, but the difference was not statistically significant at the 95 percent confidence level (MW test).

Detected concentrations of atrazine in the water samples were all less than $1 \mu \mathrm{g} / \mathrm{L}$ (table 11, in the Supplemental Information section), except for one sample (2.8 $\mu \mathrm{g} / \mathrm{L}$ ), which was below the MCL of 3 $\mu \mathrm{g} / \mathrm{L}$ set by the USEPA for atrazine (U.S. Environmental Protection Agency, 1996). No MCL has been established for deethylatrazine (U.S. Environmental Protection Agency, 1996). Atrazine is a triazine herbicide used to control annual grasses in corn fields.

Additional pesticide compounds detected in water samples included simazine, diazinon, metolachlor, alachlor, and 2,6-diethylanaline (table 11, in the Supplemental Information section, fig. 17). All these compounds were detected at concentrations less than $1 \mu \mathrm{g} / \mathrm{L}$ (except diazinon in one sample, at $19 \mu \mathrm{g} / \mathrm{L}$ ) and none of their concentrations exceeded established USEPA MCLs. Simazine is a 


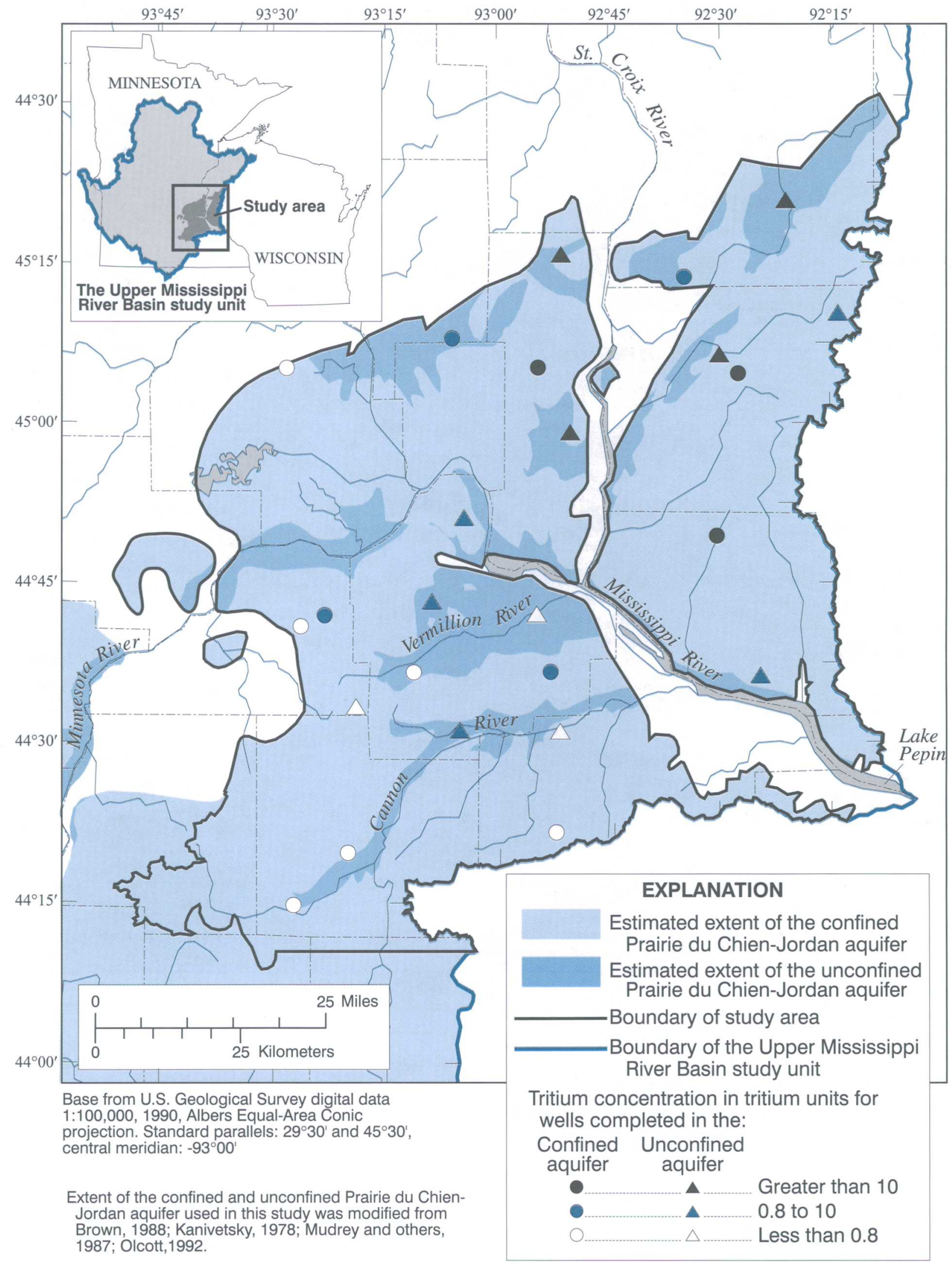

Figure 15.--Locations of wells and tritium concentrations in water samples from wells completed in the Prairie du Chien-Jordan aquifer. 


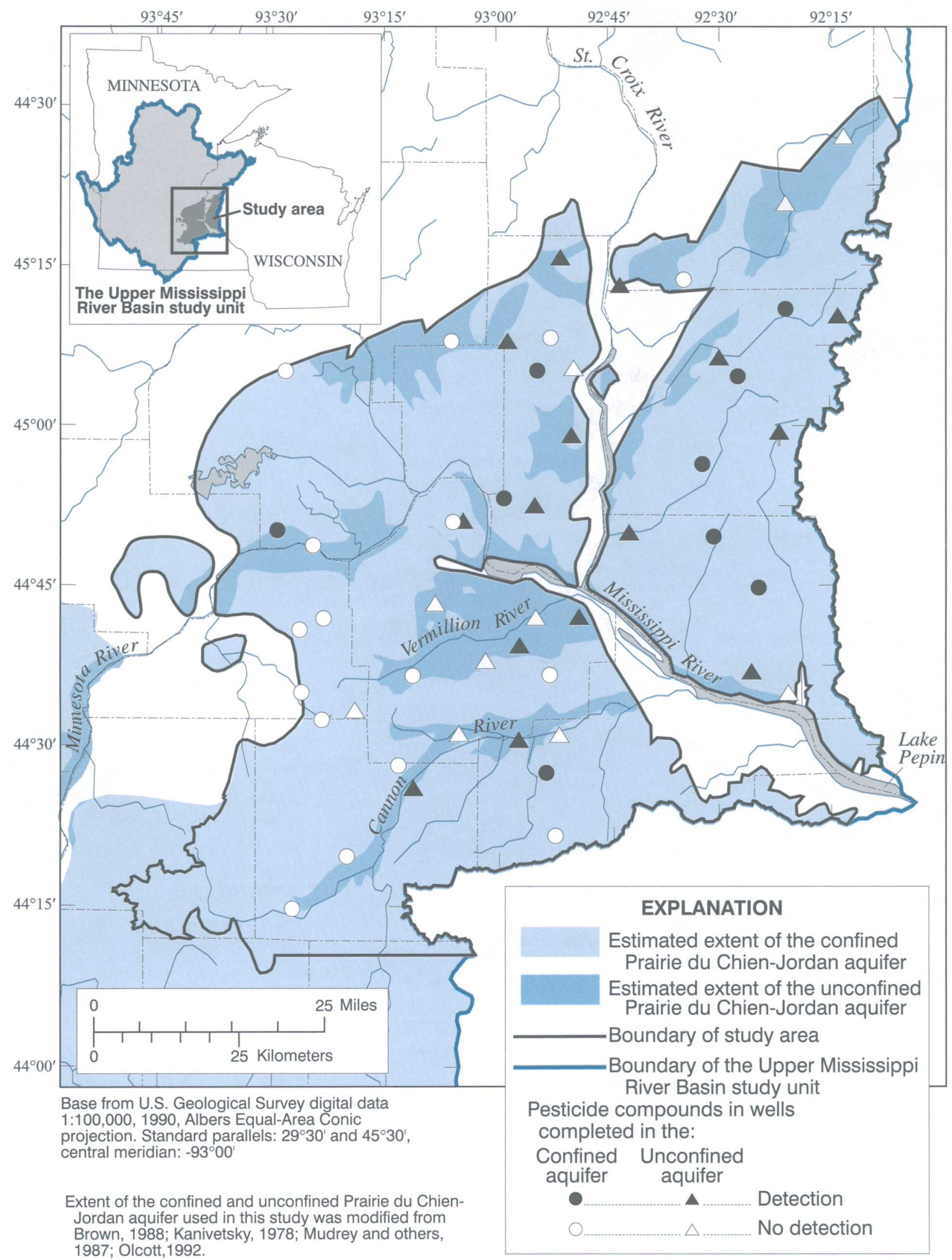

Figure 16.--Locations of Prairie du Chien-Jordan aquifer study area wells with water samples having detectable concentrations of pesticide compounds. 


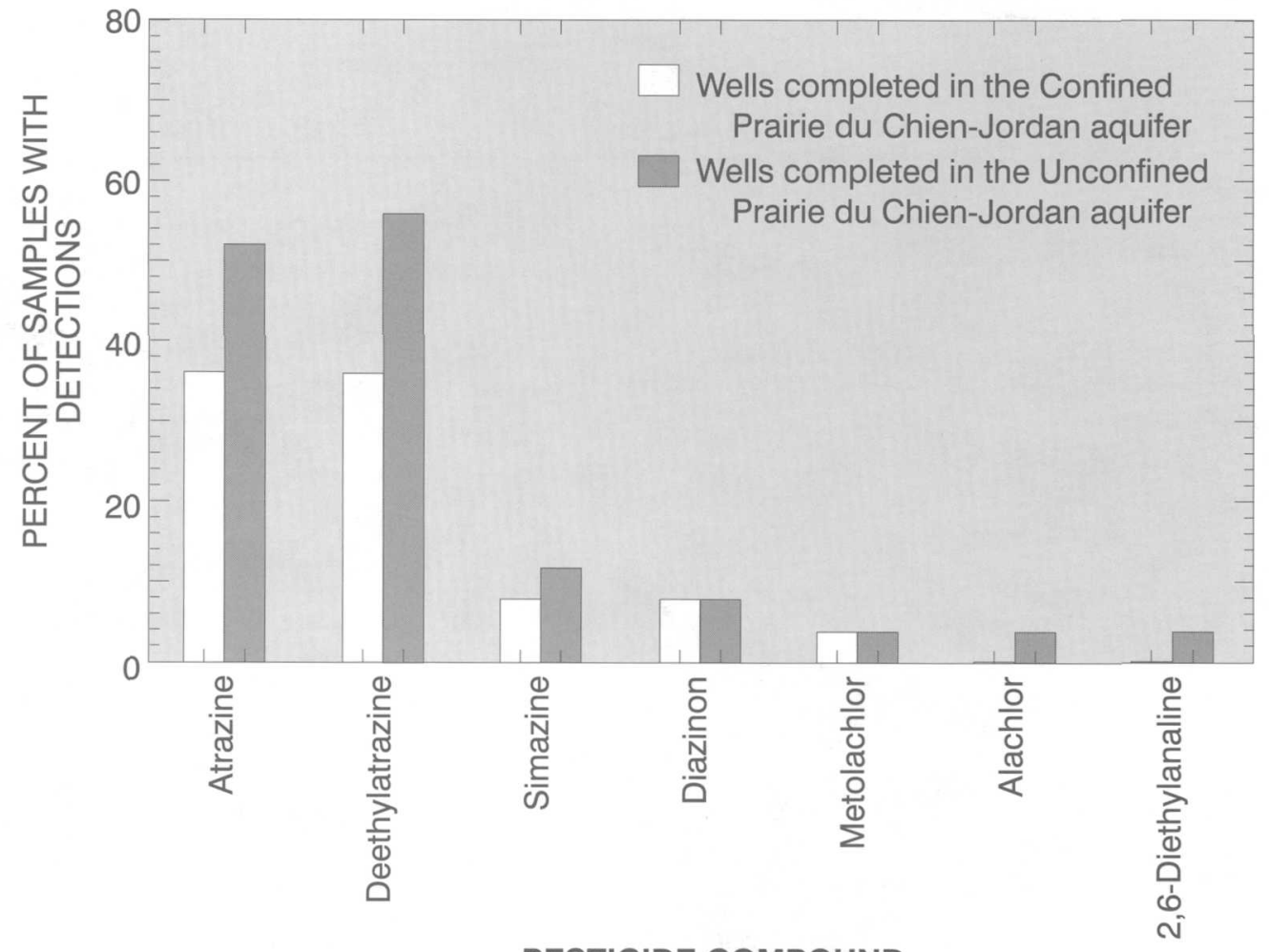

PESTICIDE COMPOUND

Figure 17.--Frequencies of detection of pesticide compounds in water samples from Prairie du Chien-Jordan aquifer study area wells.

triazine herbicide applied to corn crops and in rights-of-way to control weeds. Diazinon is a phosphorothioate compound used as an insecticide and nematicide in both agricultural and urban areas. Metolachlor is a chloroacetanilide compound used as a preemergent herbicide for corn, soybean, grain sorghum, and potato crops (Sine, 1993). It is considered to be a possible human carcinogen, with a lifetime health advisory limit of $70 \mu \mathrm{g} / \mathrm{L}$ for drinking water (U.S. Environmental Protection Agency, 1996). Metolachlor is relatively soluble in water, is moderately volatile, has a relatively low sorption coefficient to organic carbon, and has a soil half-life of 40 days (Weber, 1994). Alachlor is a chloroacetanilide herbicide used as a preemergent herbicide for corn and soybean crops and 2,6-Diethylanaline is a metabolite of alachlor.

\section{Volatile Organic Compounds}

VOCs are carbon-containing compounds that readily evaporate at normal temperature and pressure. VOCs are contained in many commercial products including gasoline, paints, adhesives, sol- vents, wood preservatives, dry-cleaning agents, pesticides, cosmetics, correction fluids, and refrigerants. VOCs may leach to ground water from spills and leaks at or near the land surface, from atmospheric dispersion into ground water, and through recharge of rainwater which contains VOCs sorbed from the atmosphere. Water samples from the wells were analyzed for 87 VOCs from several chemical groups (table 12, in the Supplemental Information section). VOCs were detected in water samples from 41 of the 50 wells, with almost all of those concentrations being less than $0.5 \mu \mathrm{g} / \mathrm{L}$ (table 13, in the Supplemental Information section, fig. 18). The concentrations tended to be slightly greater in water samples from wells in the unconfined PDCJ. These findings are consistent with results of analyses of existing data on VOC concentrations that indicate a decrease in VOC concentrations with depths of sampled wells (Andrews and others, 1995b). Additionally, more types of VOCs were detected in water samples from wells in the unconfined PDCJ (figs. 18 and 19). Differences in the frequency of VOC detections between these two groups were not statistically significant at the 95 percent confidence level (MW test). None of the concentrations of the 22 detected VOCs exceeded MCLs set by the USEPA for drinking water (U.S. Environmental Protection Agency, 1996).

The most frequently detected VOC in sampled wells was carbon disulfide (table 13 , in the Supplemental Information section, fig. 19), with detections in water samples from 26 wells. Carbon disulfide was detected more frequently in water samples from the confined portion of the PDCJ aquifer (60 percent) than in water samples from the unconfined portion of the PDCJ aquifer (44 percent) (table 13, in the Supplemental Information section, fig. 19). All detected concentrations were less than $0.1 \mu \mathrm{g} / \mathrm{L}$. No MCL for drinking water has been established for this compound. Carbon disulfide is a colorless liquid with a slightly pungent, sulfurous odor which is used in the manufacture of rayon, cellophane, carbon tetrachloride, rubber, soil disinfectants, soil conditioners, grain fumigants, herbicides, paper, pharmaceuticals, electronic vacuum tubes, and as a solvent (Verschueren, 1983). The relatively high frequency of 


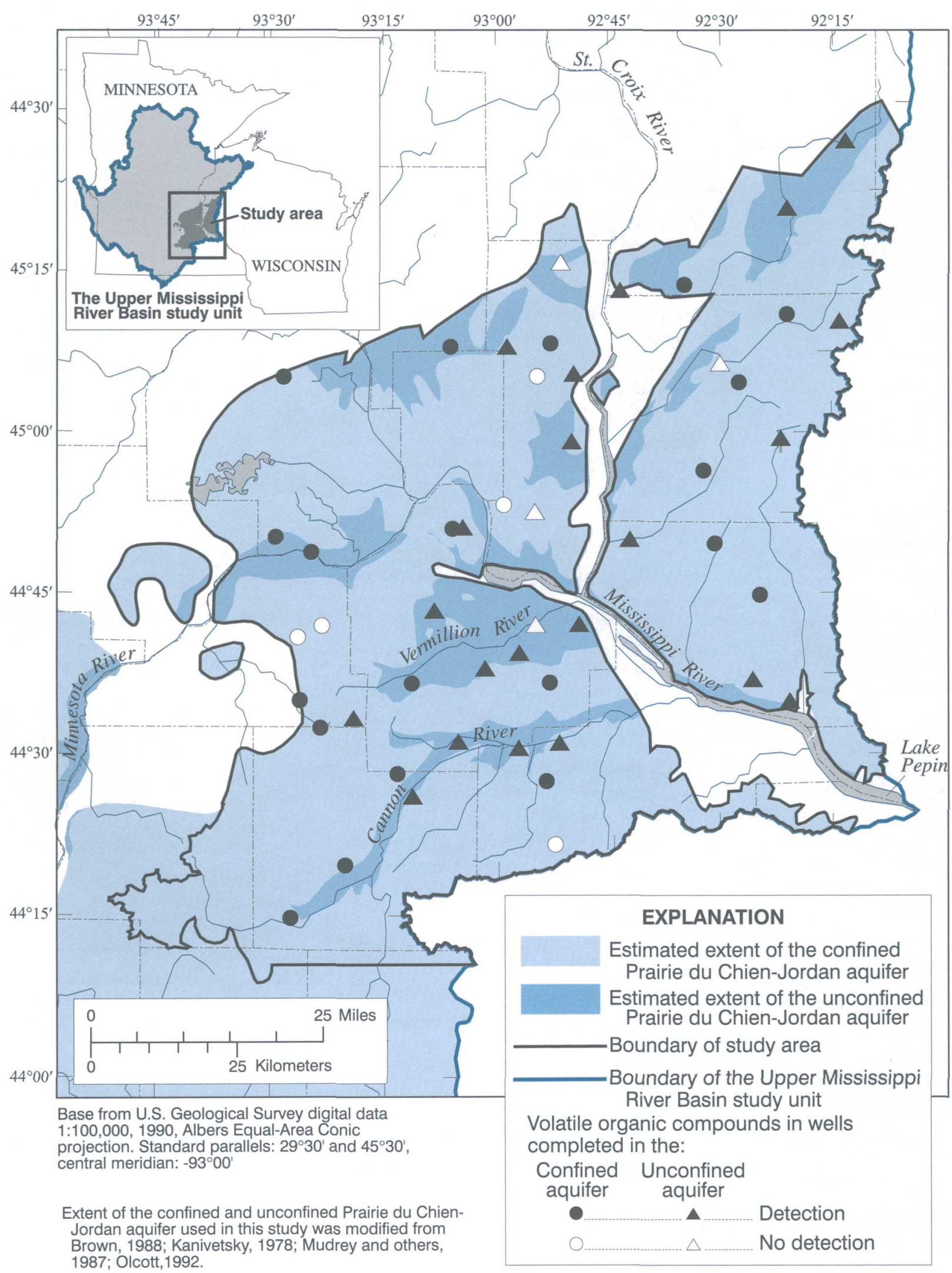

Figure 18.--Locations of Prairie du Chien-Jordan aquifer study area wells with water samples having detectable concentrations of volatile organic compounds. 


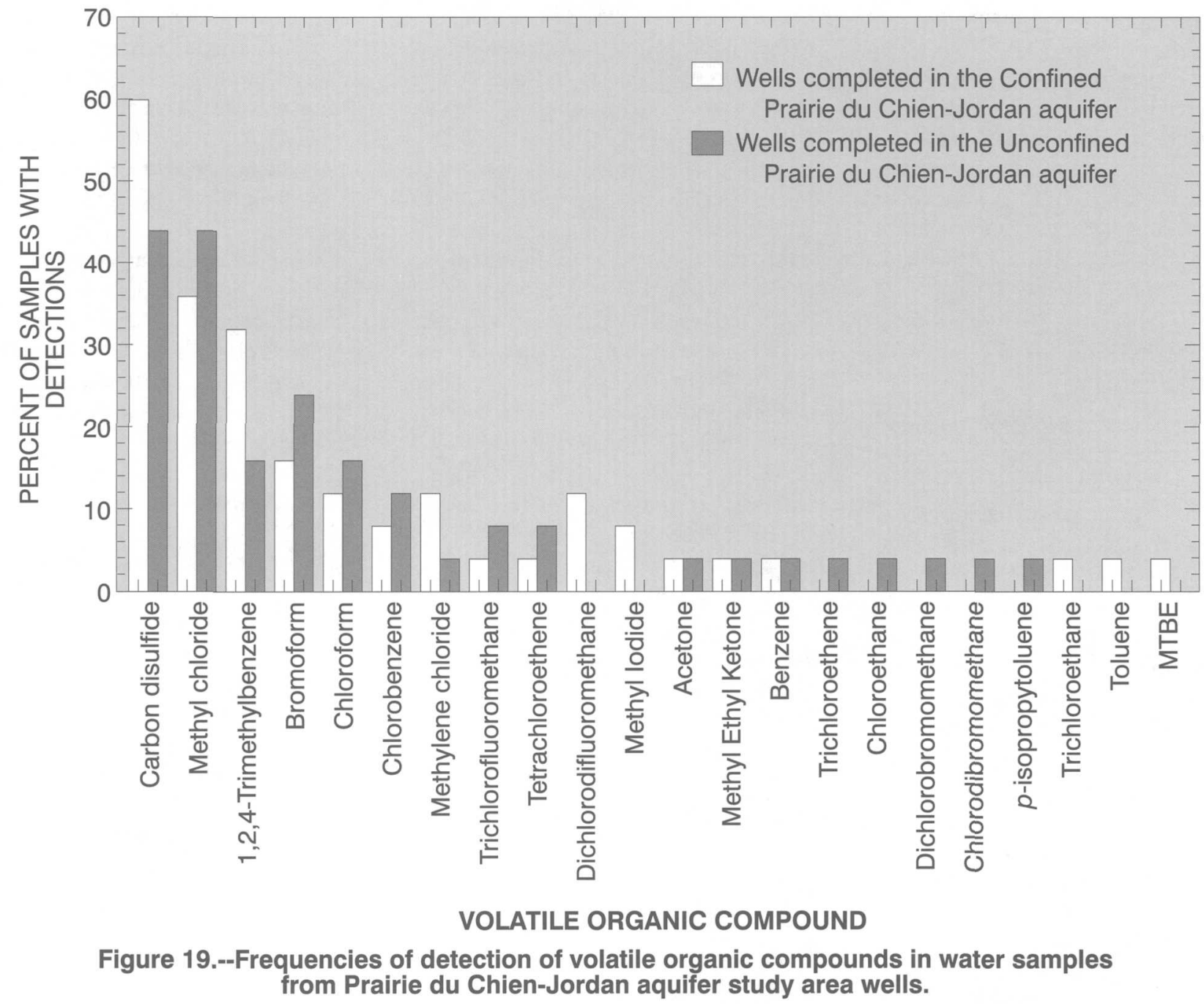

detection of this compound at low concentrations in ground water indicates a widespread source. Carbon disulfide is naturally emitted from many soils, particularly soils rich in organic matter and through bacterial interactions with sulfide minerals such as pyrite

(Verschueren, 1983). Although emissions from soils or by indigenous bacteria may be important sources of carbon disulfide, more information is needed to determine whether sources of this compound are natural or anthropogenic.

Methyl chloride, also known as chloromethane, was the second most frequently detected VOC (table 13 , in the Supplemental Information section, fig. 19) with detections in water samples from 20 wells. None of the detected concentrations exceeded $0.1 \mu \mathrm{g} / \mathrm{L}$. The frequency of detection of methyl chloride in water samples from both confined and unconfined portions of the PDCJ aquifer was similar (36 and 44 percent, respectively) (table 13, in the Supplemental Information section, fig. 19). Methyl chloride is used in the manufacture of silicone, tetraethyllead, synthetic rubber, methyl cellulose, refrigerants, methylene chloride, chloroform, carbon tetrachloride, and fumigants (Verschueren, 1983). Methyl chloride is also used as a low temperature solvent, in medicines, as fluid in thermostatic equipment, as an extractant, as a propellant, and in herbicides and medicines (Verschueren, 1983). This VOC is also present in parts-perthousand concentrations in cigarette smoke (Verschueren, 1983). Low concentrations of methyl chloride may also have been created by reactions between naturally occurring organic matter in water samples and the drops of 1:1 hydrochloric acid used to preserve the water samples. The USEPA has rated methyl chloride as a possible human carcinogen and has established a lifetime health advisory of $3 \mu \mathrm{g} / \mathrm{L}$ in drinking water (U.S. Environmental Protection Agency, 1996). None of the samples exceeded that lifetime health advisory concentration.

The compound 1,2,4-Trimethylbenzene was detected in water samples from 12 wells (table 13, in the Supplemental Information section, fig. 19). None of the detections exceeded $0.2 \mu \mathrm{g} / \mathrm{L}$. This compound is used in the manufacture of trimellitic anhydride, dyes, pharmaceuticals, and pseudocumidine (Verschueren, 1983). It is also found in high octane gasoline (Verschueren, 1983). There are no MCLs or health advisories established for this compound.

Bromoform is a trihalomethane compound that was detected at low concentrations in water samples from 10 
wells (table 13, in the Supplemental Information section, fig. 19). None of the detections exceeded $0.2 \mu \mathrm{g} / \mathrm{L}$. Bromoform is used in the manufacture of pharmaceuticals, fire-resistant chemicals, and as a solvent for waxes, greases, and oils (Verschueren, 1983). Chlorination of water containing organic compounds forms trihalomethane compounds, including bromoform. The USEPA has established an MCL of $80 \mu \mathrm{g} / \mathrm{L}$ for the sum of the concentrations of the trihalomethane compounds.

The trihalomethane compound chloroform was detected in water samples from seven of the wells (table 13, in the Supplemental Information section, fig. 19). None of the detections exceeded 0.2 $\mu \mathrm{g} / \mathrm{L}$. Primary sources of chloroform include pulp and paper mills, pharmaceutical manufacturing plants, chemical manufacturing plants, sewage treatment plants that emit chlorinated wastewater, and water utility plants that chlorinate drinking water (Agency for Toxic Substances and Disease Registry, electronic commun., 1997). Minor sources of chloroform include automobile exhaust, tobacco smoke, decomposition of trichloroethene, burning of plastics, and its use as a pesticide (Agency for Toxic Substances and Disease Registry, electronic commun., 1997). Chloroform detected in water samples from these wells may also be residual from hypochlorite used to sterilize new wells and to periodically reduce iron-bacteria buildup in well casings and plumbing systems.

Chlorobenzene was detected in water samples from five wells (table 13, in the Supplemental Information section, fig. 19). This compound is used for solvent recovery, dye manufacturing, and in the manufacture of aniline, insecticides, phenol, and chloronitrobenzene

(Verschueren, 1983).

Other VOCs detected include methylene chloride (dichloromethane), trichlorofluoromethane (CFC-11), tetrachloroethene (PCE), dichlorodifluoromethane (CFC-12), methyl iodide, acetone, methyl ethyl ketone, benzene, trichloroethene, chloroethane, bromodichloromethane, dibromochloromethane, $p$-isopropyltoluene, 1,1,1-trichloroethane, toluene, and tert-butyl methyl ether (MTBE) (table 13, in the Supplemental Information section). All were detected in water samples from fewer than five wells, with concentrations generally less than $0.5 \mu \mathrm{g} / \mathrm{L}$. None of the detected VOCs exceeded MCLs. MTBE was detected in one water sample (table 13, in the Supplemental Information section) at a concentration estimated to be $0.010 \mu \mathrm{g} / \mathrm{L}$, which is below the reporting limit of $0.100 \mu \mathrm{g} / \mathrm{L}$. MTBE is used as a fuel oxygenate to reduce the atmospheric concentrations of carbon monoxide or ozone. Possible sources of MTBE include atmospheric deposition, stormwater runoff, vehicles with gasoline purchased in areas that use MTBE, or accidental contamination of the sample at the lab. MTBE is not known to be added to gasoline in the study area, but is used and widely detected in ground water in the Denver, Colorado, metropolitan area (Bruce and McMahon, 1996).

\section{Implications of Water-Quality Variability Between Confined and Unconfined Portions of the Prairie du Chien-Jordan Aquifer}

Based on samples collected for this study, water in the unconfined portion of the PDCJ aquifer appear to be affected to a greater extent by anthropogenic activities than water in the confined portion of the aquifer. Water samples from wells completed in the confined portion of the aquifer tend to have slightly greater concentrations of dissolution products of naturally occurring materials that occur in the aquifer and the water in that portion of the aquifer generally has longer residence time. Some of the naturally occurring and anthropogenic materials in the aquifer pose nuisances or potential health hazards to consumers of water from the aquifer.

In general, differences in anthropogenic and naturally occurring materials in water between confined and unconfined portions of the PDCJ aquifer are small and frequently the differences are not statistically significant at the 95 percent confidence level. Mixing of waters between confined and unconfined portions of the aquifer, and leakage of water from overlying units, is increased by alluvium and glacial outwash filled bedrock valleys eroded into the aquifer. In addition, the presence or absence of a 10 foot-thick (clay, glacial till or bedrock) confining unit, used as the criteria to define confining units in this report, may not be sufficient to protect water in the aquifer from the influence of contaminants resulting from land-use activities. To help ensure isolation from anthropogenic contamination of wells completed in the aquifer, locating wells in areas with confining units greater than 10 feet in thickness may be desirable.

The textural composition of glacialdeposit confining units overlying the aquifer may play an important role in protection of water in the aquifer from contaminants resulting from land-use activity. Glacial deposits in the western portion (associated with the Des Moines Lobe) are more clay-rich than glacial deposits in the eastern portion of the study area (associated with the Superior Lobe). These tills are frequently intermixed and stratigraphic succession of the tills is complex. Therefore, the significance of the source of glacial tills in isolating the PDCJ aquifer from anthropogenic activity at the land surface could not be evaluated. A thorough evaluation of the distribution and extent of these glacial till units would be important in understanding the susceptibility of the aquifer to anthropogenic activity.

\section{Water-Quality Variability Between the Prairie du Chien Group and the Jordan Sand- stone Portions of the Prairie du Chien-Jordan Aquifer}

\footnotetext{
Wells selected for sampling generally were constructed so that the open intervals of the wells were isolated in either the PDC or JDN portions of the PDCJ aquifer. Of the 50 wells sampled, 33 wells are completed in the PDC and 14 wells are completed in the JDN. Analysis of water-quality data from these wells allows for a general comparison of waters
} 
from the two stratigraphic units that comprise the PDCJ aquifer.

Smith and Nemetz (1996), in a study of water-quality along selected flow paths in the PDCJ aquifer, did not find a major effect on major-ion chemistry between the stratigraphic units comprising the aquifer. Results of their work, however, indicated that ground water from the PDC had greater concentrations of nitrate, chloride, and tritium, a predominance of areas with oxidizing conditions, and shorter residence times. In comparison, ground water from the JDN had ground water with lesser concentrations of nitrate, chloride, and tritium, a predominance of areas with reducing conditions, and longer residence times. Statistical analysis indicated a significant relation between the distribution of nitrate, chloride, and tritium concentrations, with well grouting, well depth, and the presence of the overlying Decorah shale. The thickness and composition of the overlying glacial drift was shown to be significantly related to nitrate concen- trations, but not to chloride and tritium concentrations.

The only significant differences, at the 95 percent confidence level ( $t$-test and MW test), in physical parameters in water from wells completed in the PDC versus the JDN areas of the PDCJ aquifer sampled for this study were that $\mathrm{pH}$, calcium, and magnesium were slightly greater in areas where the JDN was unconfined in comparison to areas where the PDC was unconfined. There were no other statistically significant differences, at the 95 percent confidence level ( $\mathrm{t}$-test and MW test), in physical parameters among confined or unconfined portions of the PDC with confined or unconfined portions of the JDN. There also were no statistically significant differences, at the 95 percent confidence level ( $\mathrm{t}$-test), in the hardness of water from wells completed in either the PDC or JDN, regardless of whether the units were confined or unconfined.

Median concentrations of chloride were greater in the PDC than in the JDN, but the differences were not statistically significant at the 95 percent confidence level (MW test). Median concentrations of nitrate were greater in the PDC than in the JDN, but the differences also were not statistically significant at the 95 percent confidence level (MW test), regardless of whether the units were confined or unconfined. There also were no statistically significant differences, at the 95 percent confidence level (MW test), in pesticide detections between the PDC or JDN.

Saturation indices can indicate which minerals may precipitate in aquifers. Indices were calculated to determine whether water in either the PDC or JDN were saturated with mineral components using the methods outlined by Parkhurst (1995). Calcite was generally determined to be oversaturated in both the PDC and the JDN. The saturation indices in water samples were found to be similar to those found by Smith and Nemetz (1996); there was little difference in mineral saturation among the PDC and JDN portions of the PDCJ aquifer.

\section{Summary and Conclusions}

The Prairie du Chien-Jordan (PDCJ) aquifer (Prairie du Chien-Trempealeau aquifer in Wisconsin), composed of dolomite and sandstone of Cambrian to Ordovician age, is the principal bedrock aquifer in the Upper Mississippi River study unit of the National Water-Quality Assessment (NAWQA) Program. The aquifer supplies approximately 75 percent of the ground water withdrawn in the area. As part of the NAWQA Program, 50 domestic wells completed in confined and unconfined portions of this aquifer were sampled for approximately 200 constituents during July, August, and September of 1996. In certain areas, the aquifer is overlain by bedrock or glacial deposits having low hydraulic conductivity (termed "confined portion" of the aquifer in this report). In other areas the aquifer is overlain by glacial sand and gravel deposits having greater hydraulic conductivity (termed "unconfined portion" of the aquifer in this report). Differences in the hydrogeologic characteristics of these overlying units have potential to affect the downward movement of water and of contaminants from the land surface into the aquifer. The purpose of this report is to describe the chemical characteristics of water in the PDCJ aquifer and to summarize the differences in water quality in confined and unconfined portions of the aquifer. Twenty-five wells were sampled in each portion of the aquifer. Water samples from the wells were measured for physical parameters and analyzed for concentrations of major ions, nutrients, dissolved organic carbon, trace metals, radon, tritium, pesticides, and volatile organic compounds.

Differences in anthropogenic and naturally occurring materials in water between confined and unconfined portions of the PDCJ aquifer are small and frequently the differences are not significant at the 95 percent confidence level. Dissolved oxygen concentrations were slightly less (not statistically significant at the 95 percent confidence level (nonparametric Mann-Whitney test)), and specific conductances and alkalinities were greater (statistically significant at the 95 percent confidence level (two sample t-test)), in water in the confined portion of the aquifer. Concentrations of most major ions were generally greater in water from the confined portion of the aquifer.

Nitrate (nitrite plus nitrate as $\mathrm{N}$ ) and phosphorus are the primary nutrients of concern in ground water due to potential effects on human health and streams and rivers. Nitrate may leach to ground water from fertilizers and animal wastes applied to the land surface. Nitrate concentrations were generally greater in the unconfined portion of the PDCJ aquifer although the differences were not statistically significant at the 95 percent confidence level (nonparametric Mann-Whitney test). In the unconfined portion of the PDCJ aquifer, nitrate in two samples exceeded the maximum contaminant level of 10 milligrams per liter $(\mathrm{mg} / \mathrm{L})$. In the confined portion of the PDCJ aquifer no samples exceeded the maximum contaminant level of $10 \mathrm{mg} / \mathrm{L}$ for 
nitrate. Phosphorus concentrations were generally about an order of magnitude less than nitrate concentrations.

Concentrations of iron and manganese in water samples from the confined and the unconfined portions of the PDCJ aquifer exceeded secondary MCLs established by the USEPA for drinking water in 37 and 42 percent of water samples, respectively. Frequencies of detection and detected concentrations of iron and manganese were generally greater in the confined portion of the aquifer, although the differences were not statistically significant at the 95 percent confidence level (nonparametric MannWhitney test and two sample t-test). Zinc concentrations were relatively high in water samples from the PDCJ aquifer, possibly due to galvanized well casings and water-supply pipes in the domestic wells sampled.

Radon concentrations in water samples were greater than the suspended MCL of 300 picoCuries per liter $(\mathrm{pCi} / \mathrm{L})$ in 66 percent of the water samples. Radon concentrations were generally greater in water samples from the confined portion of the PDCJ aquifer, although the difference was not statistically significant at the 95 percent confidence level (two sample t-test). Median radon concentrations were 500 and $340 \mathrm{pCi} / \mathrm{L}$, confined and unconfined, respectively.

Tritium concentrations were analyzed in water samples from 25 of the 50 wells. Tritium concentrations in those samples indicated that water in the unconfined portion of the PDCJ aquifer may have been recharged more recently than water in the confined portion of the PDCJ aquifer, although differences in tritium concentrations between confined and unconfined portions of the aquifer were not statistically significant at the 95 percent confidence level (nonparametric Mann-Whitney test).

A total of seven different pesticide compounds were detected in water samples. Atrazine and its metabolite, deethylatrazine, were the most frequently detected pesticide compounds in water samples from the PDCJ aquifer. Atrazine was detected in water samples from 36 percent of wells in the confined portion of the PDCJ aquifer and from 52 percent of wells in the unconfined portion of the PDCJ aquifer, although the difference in detection rates was not statistically significant at the 95 percent confidence level (nonparametric Mann-Whitriey test). Atrazine is an herbicide commonly applied to corn crops. Several of the other detected pesticides, including simazine, metolachlor, and alachlor, are also applied to corn, which is commonly grown in the study area.

Volatile organic compounds (VOCs) were detected in all but nine of the water samples, but none at concentrations exceeding 1 microgram per liter. Carbon disulfide, which may be naturally emitted from soils and bacteria, and methyl chloride were the most frequently-detected VOCs in water samples from the PDCJ aquifer. A greater number of VOCs were detected in water samples from the unconfined portion of the PDCJ aquifer and VOCs were detected at slightly greater concentrations in the unconfined portion of the aquifer, although the difference in detection rates was not statistically significant at the 95 percent confidence level (nonparametric Mann-Whitney test).

Water in the unconfined portion of the PDCJ aquifer in Minnesota and Wisconsin appears to be affected to a greater degree by anthropogenic activities than water in the confined portion of the aquifer. Water samples from wells completed in the confined portion of the aquifer tend to have slightly greater concentrations of dissolution products of naturally occurring materials in the aquifer and water in that portion of the aquifer generally has a longer residence time. Some of the naturally occurring and anthropogenic materials in the aquifer pose nuisances or potential health hazards to consumers of water from the aquifer. In general, however, differences in anthropogenic and naturally occurring materials among confined and unconfined portions of the PDCJ aquifer are small and frequently not statistically significant. 


\section{References}

Aieta, E.M., Singley, J.E., Trussel, A.R., Thorbjarnarson, K.W., and McGuire, M.J., 1987, Radionuclides in drinking water-An overview: Journal of the American Water Works Association, v. 79, p. 144-152.

Alexander, S.C., and Alexander, E.C., 1989, Residence times in Minnesota ground waters: Journal of the Minnesota Academy of Science, v. 55, no. $1,5 \mathrm{p}$.

American Society for Testing and Materials, 1996, Annual Book of ASTM Standards, section 11, Water and Environmental Technology: American Society for Testing and Materials, v. 11.02, D5072-92, p. 674-676.

Andrews, W.J., Trotta, L.C., and Schoenberg, M.E., 1995a, Waterlevel declines from 1980-90 in major aquifers in the Twin Cities area: Proceedings of the 31 st annual conference and symposia of the American Water Resources Association, Houston, Texas, November 5-9, 1995, p. 63-72.

Andrews, W.J., Fallon, J.D., and Kroening, S.E., 1995b, Water-quality assessment of part of the Upper Mississippi River Basin, Minnesota and Wisconsin-Volatile organic compounds in surface and ground water, 1978-94: U.S. Geological Survey Water-Resources Investigations Report 95-4216, 39 p.

Baker, D.G., Nelson, W.W., and Kuehnast, E.L., 1979, Climate of Minnesota Part XII-The hydrologic cycle and soil water: Agricultural Experiment Station Technical Bulletin 322, University of Minnesota, $24 \mathrm{p}$.

Bloomgren, B.A., Cleland, J.M., and Olsen, B.M., 1989, Depth to bedrock and bedrock topography, in Balaban, N.H., ed., 1989, Geologic AtlasHennepin County, Minnesota: Minnesota Geological Survey, County Atlas Series, C-4, 8 pl.
Brenton, R.W., and Arnett, T.L., 1993, Methods of analysis by the U.S. Geological Survey National Water Quality Laboratory-Determination of dissolved organic carbon by UVpromoted persulfate oxidation and infrared spectrometry: U.S. Geological Survey Open-File Report 92-480, $12 \mathrm{p}$.

Brown, B.A., 1988, Bedrock geology of Wisconsin: Wisconsin Geological and Natural History Survey Map 887, 1 sheet, scale 1:250,000.

Bruce, B.W., and McMahon, P.B., 1996, Shallow ground-water quality beneath a major urban center: Journal of Hydrology, v. 186, no. 14, p. 129-151.

Cothern, C.R., 1987, Development of regulations for radionuclides in drinking water, in Graves, B., ed., Radon, radium, and other radioactivity in ground water: Lewis Publishers, Chelsea, Mich., p. 1-11.

Crawford-Brown, D.J., 1990, Analysis of the health risk from ingested radon, in Cothern, C.R., and Rebers, P.A., eds., Radon, radium, and uranium in drinking water: Lewis Publishers, Chelsea, Michigan, p. 17-26.

Delin, G.N., and Woodward, D.G., 1984, Hydrogeologic setting and the potentiometric surfaces of regional aquifers in the Hollandale Embayment, southeastern Minnesota, 1970-1980: U.S. Geological Survey Water-Supply Paper 2219, 56 p.

Dorsch, M.M., Scragg, R.K.R., McMichael, A.J., Baghurst, P.A., and Dyer, K., 1984, Congenital malformations and maternal drinking water supply in rural South Australia-A case-control study: American Journal of Epidemiology, v. 119, p. $473-480$.

Drever, J.I., 1988, The geochemistry of natural waters $(2 \mathrm{~d}$ ed.): PrenticeHall, Englewood Cliffs, New Jersey, p. 379.

Durfor, C.N, and Becker, E., 1964, Public water supplies of the 100 largest cities in the United States, 1962: U.S. Geological Survey Water-Supply Paper 1812, 364 p.
Fan, A.M., Wilhite, C.C., and Book, S.A., 1987, Evaluation of the nitrate drinking water standard with reference to infant methemoglobinemia and potential reproductive toxicity: Regulatory Toxicology and Pharmacology, v. 7, p. 135-137.

Farnsworth, D.K., Thompson, E.S., and Peck, E.L., 1982, Annual free water surface (FWS) evaporation shallow lake, 1956-1970: National Oceanic and Atmospheric Administration evaporation atlas for the contiguous 48 United States, map 3 in pocket, scale $1: 4,800,000$.

Fishman, M.J., 1993, Methods of analysis by the U.S. Geological Survey National Water Quality Laboratory-Determination of inorganic and organic constituents in water and fluvial sediments: U.S. Geological Survey Open-File Report 93-125, $217 \mathrm{p}$.

Forman, D., Al-Dabbagh, S., and Doll, R., 1985, Nitrates, nitrites, and gastric cancer in Great Britain: Nature, v. 313, p. 620-625.

Green, J.C., 1977, Keweenawan plateau volcanism in the Lake Superior region, in Baragen, W.R., Coleman, L.C., and Hall, J.M. eds., Volcanic regimes in Canada: Geological Association of Canada Special Paper 15 , p. 407-422.

Hem, J.D., 1985, Study and interpretation of the chemical characteristics of natural water ( $3 \mathrm{~d}$ ed.): U.S. Geological Survey Water-Supply Paper 2254, $263 \mathrm{p}$.

Hitt, K.J., 1994, Refining 1970's land use data with 1990 population data to indicate new residential development: U.S. Geological Survey Water-Resources Investigations Report 94-4250, at URL http://wwwrvares.er.usgs.gov/ nawqa/WRI94-4250.html.

Kanivetsky, Roman, 1978, Hydrogeologic map of Minnesota, Bedrock Hydrogeology: Minnesota Geological Survey, State Map Series S-2, 2 sheets, scale 1:500,000. 
Koterba, M.T., Wilde, F.D., and Lapham, W.W., 1995, Ground-water datacollection protocols and procedures for the National Water-Quality Assessment Program-Collection and documentation of water-quality samples and related data: U.S. Geological Survey Open-File Report 95-399, 113 p.

Madison, R.J., and Brunett, J.O., 1984, Overview of the occurrence of nitrate in ground water of the United States, in National Water Summary, 1984: U.S. Geological Survey Water-Supply Paper 2275, p. 93-105.

Majewski, M.S., and Capel, P.D., 1995, Pesticides in the atmosphereDistribution, trends, and governing factors: U.S. Geological Survey Open-File Report 94-506, 191 p.

Menheer, M.A., and Brigham, M.E., 1997, Ground-water sampling methods and quality-control data for the Red River of the North Basin, Minnesota, North Dakota, and South Dakota, 1993-95: U.S. Geological Survey Water-Resources Investigations Report 96-4317, 34 p.

Metropolitan Council, 1992, Twin Cities Metropolitan Area water supply-A plan for action: Metropolitan Council, no. 590-92-025, St. Paul, Minnesota, $72 \mathrm{p}$.

Meyer, G.N., and Hobbs, H.C., 1989, Surficial Geology, in Balaban, N.H., ed., Geologic Atlas-Hennepin County, Minnesota: Minnesota Geological Survey County Atlas Series, C-4, 8 pls.

Mudrey, M.G., Jr., LaBarge, G.A., Myers, P.E., and Cordua, W.S., 1987, Bedrock geology of Wisconsin: Wisconsin Geological and Natural History Survey Map 8711a, 2 sheets, scale 1:250,000.

National Research Council, 1985, Health effects of nitrate and $\mathrm{N}$-nitroso compounds: National Academy Press, Washington, D.C., 723 p.

National Research Council, 1988, Health risks of radon and other internally deposited alpha-emitters: National Academy Press, Washington, D.C., $624 \mathrm{p}$.
Nemetz, D.A., 1993, The geochemical evolution of ground water along flow paths in the Prairie du Chien-Jordan aquifer of southeastern Minnesota: University of Minnesota, M.S. thesis, $182 \mathrm{p}$.

Norvitch, R.F., Ross, T.G., and

Brietkrietz, A., 1973, Water resources outlook for the Minneapolis-Saint Paul metropolitan area, Minnesota: Twin Cities Metropolitan Council, 219 p.

Olcott, P.G., 1992, Ground-water atlas of the United States, Segment 9, Iowa, Michigan, Minnesota, and Wisconsin: U.S. Geological Survey Hydrologic Investigations Atlas 730J, 31 p., scales 1:250,000 and 1:500,000.

Ostlund, H.G., and Dorsey, H.G., 1975, Rapid electrolytic enrichment of hydrogen gas proportional counting of tritium: International Conference on Low Radioactivity Measurement and Applications, High Tatras, Czechoslovakia, October 1975 [Proceedings], $6 \mathrm{p}$.

Parkhurst, D.L., 1995, User's guide to PHREEQC--C computer program for speciation, reaction-path, advectivetransport, and inverse geochemical calculations: U.S. Geological Survey Water-Resources Investigations Report 95-4227, 143 p.

Plummer, L.N., Michel, R.L., Thurman, E.M., and Glynn, P.D., 1993, Environmental tracers for age-dating young ground water, in Alley, W.M., Regional ground-water quality: Van Nostrand Reinhold, New York, p. 255-294.

Rao, P.S.C., and Alley, W.M., 1993, Pesticides, in Alley, W.M., ed., Regional ground-water quality: Van Nostrand Reinhold, New York, p. 345-382.

Rose, D.L., and Schroeder, M.P., 1995, Methods of analysis by the U.S. Geological Survey National Water Quality Laboratory-Determination of volatile organic compounds in water by purge and trap capillary gas chromatography/mass spectrometry: U.S. Geological Survey Open File Report 94-708, 26 p.
Schoenberg, M.E., 1990, Effects of present and projected ground-water withdrawals on the Twin Cities aquifer system, Minnesota: U.S. Geological Survey Water-Resources Investigations Report 90-4001, $165 \mathrm{p}$.

Scott, J.C., 1990, Computerized stratified random site-selection approaches for design of a ground-water-quality sampling network: U.S. Geological Survey Water-Resources Investigations Report 90-4101, $109 \mathrm{p}$.

Setterholm, D.R., Runkel, A.C., Cleland, J.M., Tipping, R.G., Mossler, J.H., Kanivetsky, R., and Hobbs, H.C., 1991, Geologic factors affecting the sensitivity of the Prairie du ChienJordan aquifer: Minnesota Geological Survey Open File Report 91-5, 18 p., 12 pls.

Sine, C., ed., 1993, Farm chemical handbook '93: Meister Publishing Company, Willoughby, Ohio, variously paged.

Smith, S.E., and Nemetz, D.A., 1996, Water quality along selected flow paths in the Prairie du Chien-Jordan aquifer, southeastern Minnesota: U.S. Geological Survey WaterResources Investigations Report 95$4115,76 \mathrm{p}$.

Spencer, W.F., and Cliath, M.M., 1990, Movement of pesticides from soil to the atmosphere, in Long range transport of pesticides: Lewis Publishers, Inc., Chelsea, Michigan, 462 p.

Stark, J.R., Andrews, W.J., Fallon, J.D., Fong, A.L., Goldstein, R.M., Hanson, P.E., Kroening, S.E., and Lee, K.E, 1996, Water-quality assessment of part of the Upper Mississippi River Basin, Minnesota and Wisconsin-Environmental setting and study design: U.S. Geological Survey Water-Resources Investigations Report 96-4098, 62 p. 
U. S. Bureau of Census, 1991, Census of Population and Housing, 1990:

Public Law (P.L.) 94-171, data from compact disk ROM (Iowa,

Minnesota, North Dakota, South

Dakota, and Wisconsin), Washington DC.

U.S. Environmental Protection Agency, 1996, Drinking water regulations and health advisories: U.S.

Environmental Protection Agency, Office of Water, EPA 822-B-96-002, October, $9 \mathrm{p}$.

Verschueren, Karel, 1983, Handbook of environmental data on organic chemicals: New York, Van Nostrand Reinhold, $1310 \mathrm{p}$.

Wall, D.B., Montgomery, B.R., Deluca, D., Meyers, G., and Thomas, D., 1991, Nitrogen in Minnesota ground water. Prepared for the Legislative Water Commission: Minnesota
Pollution Control Agency and Minnesota Department of Agriculture, variously paged.

Wall, D.B., and Regan, C.P., 1994, Water quality and sensitivity of the Prairie du Chien-Jordan aquifer in westcentral Winona County: Minnesota Pollution Control Agency, Water Quality Division, 65 p.

Wanty, R.B., and Nordstrom, D.K., 1993, Natural radionuclides, in Alley, W.M., ed., Regional ground-water quality: Van Nostrand Reinhold, New York, p. 423-441.

Weber, J.B., 1994, Properties and behavior of pesticides in soil, in Honeycutt, R.C, and Schabacker, D.J., eds., Mechanisms of pesticide movement into ground water: Lewis Publishers, Boca Raton, Fla., p. 15-41.
Young, H.L., 1992a, Summary of ground-water hydrology of the Cambrian-Ordovician aquifer system in the northern Midwest, United States: U.S. Geological Survey Professional Paper 1405-A, 55 p.

1992b, Hydrogeology of the Cambrian-Ordovician aquifer system in the northern Midwest, United States: U.S. Geological Survey Professional Paper 1405-B, 99 p.

Zaugg, S.D., Sandstrom, M.W., Smith, S.G., and Fehlberg, K.M., 1995, Methods of analysis by the U.S. Geological Survey National Water Quality Laboratory-Determination of pesticides in water by C-18 solid phase extraction and capillarycolumn gas chromatography/mass spectrometry with selected-ion monitoring: U.S. Geological Survey Open-File Report 95-181, 60 p. 
Supplemental Information 
Table 1. Medians, standard deviations, and ranges in well characteristics and values of physical parameters in water samples from Prairie du Chien-Jordan study area wells

[ $\mu \mathrm{S} / \mathrm{cm}$, microsiemens per centimeter; $\mathrm{mg} / \mathrm{L}$, milligrams per liter; <, less than; NTU, nephelometric turbidity units]

\begin{tabular}{|c|c|c|c|c|c|c|c|}
\hline \multirow{2}{*}{$\begin{array}{c}\text { Well } \\
\text { characteristic or } \\
\text { physical } \\
\text { parameter }\end{array}$} & \multirow{2}{*}{ Units } & \multicolumn{3}{|c|}{ Unconfined portion of aquifer } & \multicolumn{3}{|c|}{ Confined portion of aquifer } \\
\hline & & Median & $\begin{array}{r}\text { Standard } \\
\text { deviation }\end{array}$ & Range & Median & $\begin{array}{l}\text { Standard } \\
\text { deviation }\end{array}$ & Range \\
\hline Well depth & $\begin{array}{l}\text { Feet below land } \\
\text { surface }\end{array}$ & 180 & 92 & $66-340$ & 200 & 94 & $105-400$ \\
\hline Casing depth & $\begin{array}{l}\text { Feet below land } \\
\text { surface }\end{array}$ & 126 & 86 & $40-301$ & 175 & 92 & $68-360$ \\
\hline Depth to water ${ }^{1}$ & $\begin{array}{l}\text { Feet below land } \\
\text { surface }\end{array}$ & 28.0 & 54.3 & $13.4-218.1$ & 83.5 & 56.2 & $13.4-214$ \\
\hline Water temperature & ${ }^{\circ}$ Celsius & 12.4 & 1.9 & $9.8-16.7$ & 12.7 & 2.7 & $9.5-18.8$ \\
\hline $\mathrm{pH}$ & $\mathrm{pH}$ units & 7.5 & 0.2 & 7.1-8.1 & 7.4 & 0.2 & $7.1-7.9$ \\
\hline $\begin{array}{l}\text { Specific conduc- } \\
\text { tance }\end{array}$ & $\mu \mathrm{S} / \mathrm{cm}$ at $25^{\circ} \mathrm{C}$ & 482 & 120 & $310-742$ & 560 & 154 & $287-856$ \\
\hline $\begin{array}{l}\text { Dissolved oxygen } \\
\text { concentration }\end{array}$ & $\mathrm{mg} / \mathrm{L}$ & 1.7 & 3.4 & $<0.1-10.5$ & 0.5 & 3.8 & $<0.1-11.5$ \\
\hline Turbidity & NTU & 1.5 & 8.9 & $0.15-44$ & 1.9 & 2.4 & $0-12.4$ \\
\hline Alkalinity & $\begin{array}{l}\mathrm{mg} / \mathrm{L} \text { as } \\
\mathrm{CaCO}_{3}\end{array}$ & 216 & 62 & $117-373$ & 267 & 94 & $113-438$ \\
\hline
\end{tabular}

\footnotetext{
${ }^{1}$ Water levels measured in 14 of 25 wells completed in unconfined portions of the aquifer and in 15 of 25 wells completed in confined portions of the aquifer.
}

Table 2. Laboratory analysis methods for measured water-quality constituents

\begin{tabular}{|c|c|c|}
\hline $\begin{array}{l}\text { Constituent or constituent } \\
\text { group }\end{array}$ & Analysis method & Reference \\
\hline $\begin{array}{l}\text { Major ions } \\
\text { (USGS schedule 2750) }\end{array}$ & Atomic absorption spectrometric & Fishman (1993) \\
\hline $\begin{array}{c}\text { Nutrients } \\
\text { (USGS schedule 2752) }\end{array}$ & Various methods & Fishman (1993) \\
\hline $\begin{array}{l}\text { Dissolved organic carbon } \\
\text { (USGS schedule 2085) }\end{array}$ & $\begin{array}{l}\text { UV-promoted persulfate oxidation and infra- } \\
\text { red spectrometry }\end{array}$ & Brenton and Arnett (1993) \\
\hline $\begin{array}{l}\text { Trace metals } \\
\text { (USGS schedule 2703) }\end{array}$ & Atomic absorption spectrometric & Fishman (1993) \\
\hline $\begin{array}{c}\text { Radon } \\
\text { (USGS labcode 1369) }\end{array}$ & Liquid scintillation & $\begin{array}{l}\text { American Society for Testing } \\
\text { and Materials (1996) }\end{array}$ \\
\hline $\begin{array}{l}\text { Tritium } \\
\text { (USGS labcode 1565) }\end{array}$ & Electrolytic enrichment with gas counting & Ostlund and Dorsey (1975) \\
\hline $\begin{array}{c}\text { Pesticides } \\
\text { (USGS schedule 2010) }\end{array}$ & $\begin{array}{l}\text { Solid-phase extraction using a C-18 cartridge } \\
\text { and gas chromatography/mass spectrometry }\end{array}$ & Zaugg and others (1995) \\
\hline $\begin{array}{l}\text { Volatile organic compounds } \\
\text { (USGS custom method 9090) }\end{array}$ & $\begin{array}{l}\text { Purge and trap capillary-column gas chroma- } \\
\text { tography/mass spectrometry }\end{array}$ & Rose and Schroeder (1995) \\
\hline
\end{tabular}


Table 3. Reporting limits and concentrations of analytes in blanks

[na, not analyzed; E, detection with estimated concentration; --, not detected]

\begin{tabular}{|c|c|c|c|c|}
\hline \multirow[b]{2}{*}{ Compound } & \multirow[b]{2}{*}{ Reporting limit and unit } & \multicolumn{3}{|c|}{ Concentration } \\
\hline & & $\begin{array}{l}\text { Field/equipment } \\
\text { blanks }\end{array}$ & $\begin{array}{l}\text { Volatile organic } \\
\text { compounds trip } \\
\text { blank }\end{array}$ & $\begin{array}{l}\text { Source solution } \\
\text { blank }\end{array}$ \\
\hline Calcium & $0.02 \mathrm{mg} / \mathrm{L}$ & $0.03-0.16$ & na & -- \\
\hline Magnesium & $.01 \mathrm{mg} / \mathrm{L}$ & $0.02-0.03$ & na & -- \\
\hline Sodium & $.20 \mathrm{mg} / \mathrm{L}$ & 0.20 & na & -- \\
\hline Silica & $.01 \mathrm{mg} / \mathrm{L}$ & $0.07-0.32$ & na & 0.06 \\
\hline Nitrate-nitrogen & $.050 \mathrm{mg} / \mathrm{L}$ & 0.090 & na & 0.070 \\
\hline Ammonia-nitrogen & $.015 \mathrm{mg} / \mathrm{L}$ & -- & na & 0.020 \\
\hline Phosphorus & $.010 \mathrm{mg} / \mathrm{L}$ & 0.050 & na & -- \\
\hline Dissolved organic carbon & $.1 \mathrm{mg} / \mathrm{L}$ & $0.40-13$ & na & -- \\
\hline Iron & $3.0 \mu \mathrm{g} / \mathrm{L}$ & 3.0 & na & -- \\
\hline Zinc & $1.0 \mu \mathrm{g} / \mathrm{L}$ & $5.0-36$ & na & -- \\
\hline Manganese & $1.0 \mu \mathrm{g} / \mathrm{L}$ & $1.0-2.0$ & na & -- \\
\hline Barium & $1.0 \mu \mathrm{g} / \mathrm{L}$ & $31.0-5.0$ & na & -- \\
\hline Chromium & $1.0 \mu \mathrm{g} / \mathrm{L}$ & 2.0 & na & -- \\
\hline Aluminum & $1.0 \mu \mathrm{g} / \mathrm{L}$ & $3.0-9.0$ & na & 3.0 \\
\hline Nickel & $1.0 \mu \mathrm{g} / \mathrm{L}$ & 1.0 & na & -- \\
\hline Copper & $1.0 \mu \mathrm{g} / \mathrm{L}$ & $2.0-3.0$ & na & -- \\
\hline Carbon disulfide & $.050 \mu \mathrm{g} / \mathrm{L}$ & E0.010-E0.040 & -- & E0.040 \\
\hline Methyl chloride & $.200 \mu \mathrm{g} / \mathrm{L}$ & -- & E0.010 & -- \\
\hline 1,2,4-Trimethylbenzene & $.200 \mu \mathrm{g} / \mathrm{L}$ & $\mathrm{E} 0.020$ & -. & $\mathrm{E} 0.010$ \\
\hline Chloroform ${ }^{1}$ & $.050 \mu \mathrm{g} / \mathrm{L}$ & E0.060-E0.070 & -- & 0.260 \\
\hline Chlorobenzene & $.050 \mu \mathrm{g} / \mathrm{L}$ & $\mathrm{E} 0.002$ & -- & $\mathrm{E} 0.090$ \\
\hline Methylene chloride ${ }^{1}$ & $.100 \mu \mathrm{g} / \mathrm{L}$ & E0.060 & -- & E0.130 \\
\hline Tetrachloroethene & $.050 \mu \mathrm{g} / \mathrm{L}$ & $\mathrm{E} 0.002$ & -- & E0.010 \\
\hline Methyl ethyl ketone & $5.00 \mu \mathrm{g} / \mathrm{L}$ & $1.20-3.80$ & -- & E1.30 \\
\hline Acetone & $5.00 \mu \mathrm{g} / \mathrm{L}$ & E1.90-4.20 & -- & -- \\
\hline Benzene & $.050 \mu \mathrm{g} / \mathrm{L}$ & $\mathrm{E} 0.050$ & -- & -- \\
\hline Toluene & $.050 \mu \mathrm{g} / \mathrm{L}$ & E0.050-0.250 & -- & 0.120 \\
\hline 1,2-Dichlorobenzene & $.050 \mu \mathrm{g} / \mathrm{L}$ & -- & -- & E0.020 \\
\hline 1,3-Dichlorobenzene & $.050 \mu \mathrm{g} / \mathrm{L}$ & -- & -- & E0.007 \\
\hline 1,4-Dichlorobenzene & $.050 \mu \mathrm{g} / \mathrm{L}$ & -- & -- & E0.020 \\
\hline Styrene & $.050 \mu \mathrm{g} / \mathrm{L}$ & E0.010 & - & E0.030 \\
\hline ortho-Xylene & $.050 \mu \mathrm{g} / \mathrm{L}$ & E0.009 & -- & -- \\
\hline Methyl isobutyl ketone & $5.00 \mu \mathrm{g} / \mathrm{L}$ & E0.200-E0.300 & -- & -- \\
\hline
\end{tabular}

${ }^{1}$ These compounds were also detected by the lab in certification tests of the blank water used. 
Table 4. Reporting limits and percent recoveries for schedule 2010 pesticide spikes

[ $\mu \mathrm{g} / \mathrm{L}$, micrograms per liter; nd, not determined]

\begin{tabular}{|c|c|c|c|c|c|}
\hline \multirow[b]{2}{*}{ Compound } & \multirow[b]{2}{*}{$\begin{array}{c}\text { Reporting } \\
\operatorname{limit}(\mu \mathrm{g} / \mathrm{L})\end{array}$} & \multirow[b]{2}{*}{$\begin{array}{l}\text { Range in } \\
\text { percent } \\
\text { recovery }\end{array}$} & \multicolumn{3}{|c|}{ Mean percent recovery } \\
\hline & & & Spike \#1 & Spike \#2 & Spike \#3 \\
\hline Acetochlor & 0.002 & $102-115$ & 114 & 113 & 102 \\
\hline Alachlor & .002 & $113-128$ & 126 & 124 & 115 \\
\hline Atrazine & .001 & $90.3-112$ & 109 & 107 & 93.0 \\
\hline Azinphos-methyl & .001 & $117-198$ & 159 & 192 & 122 \\
\hline Benfluralin & .002 & $119-138$ & 127 & 130 & 125 \\
\hline Butylate & .002 & 78.8-109 & 99.2 & 90.1 & 80.9 \\
\hline Carbaryl & .003 & $182-213$ & 203 & 212 & 193 \\
\hline Carbofuran & .003 & $150-186$ & 167 & 182 & 154 \\
\hline Chlorpyrifos & .004 & $94.3-103$ & 97.3 & 99.9 & 95.8 \\
\hline Cyanazine & .004 & $131-139$ & 134 & 134 & 137 \\
\hline Dacthal (DCPA) & .002 & $103-124$ & 106 & 103 & 120 \\
\hline$p, p^{\prime}-\mathrm{DDE}$ & .006 & $66.7-79.1$ & 69.0 & 67.8 & 75.0 \\
\hline Deethylatrazine & .002 & $48.3-95.3$ & 55.3 & 71.8 & 80.2 \\
\hline Diazinon & .002 & $103-111$ & 109 & 108 & 104 \\
\hline Dieldrin & .001 & $80.1-95.2$ & 94.8 & 94.2 & 80.2 \\
\hline 2,6-Diethylanaline & .003 & $69.3-83.7$ & 70.9 & 81.6 & 70.7 \\
\hline Disulfoton & .017 & $11.5-86.4$ & 82.8 & 19.1 & 81.7 \\
\hline EPTC (eptam) & .002 & $78.2-97.4$ & 90.4 & 90.6 & 78.4 \\
\hline Ethalfluralin & .004 & $128-151$ & 142 & 143 & 133 \\
\hline Ethoprop & .003 & $108-126$ & 112 & 109 & 121 \\
\hline Fonofos & .003 & $103-107$ & 103 & 106 & 105 \\
\hline$\alpha-\mathrm{HCH}$ & .002 & $93.1-111$ & 94.0 & 98.5 & 109 \\
\hline$\gamma$-HCH (lindane) & .004 & $93.1-110$ & 94.4 & 101 & 108 \\
\hline Linuron & .002 & $142-172$ & 157 & 168 & 150 \\
\hline Malathion & .005 & $131-143$ & 134 & 141 & 138 \\
\hline Methyl parathion & .006 & $139-167$ & 162 & 162 & 150 \\
\hline Metolachlor & .002 & $126-136$ & 133 & 128 & 129 \\
\hline Metribuzin & .004 & $107-127$ & 114 & 118 & 112 \\
\hline Molinate & .004 & $81.5-113$ & 99.7 & 93.9 & 87.1 \\
\hline Napropamide & .003 & $101-105$ & 104 & 103 & 103 \\
\hline Parathion & .004 & $124-143$ & 131 & 135 & 133 \\
\hline
\end{tabular}


Table 4. Reporting limits and percent recoveries for schedule 2010 pesticide spikes--Continued $[\mu \mathrm{g} / \mathrm{L}$, micrograms per liter; nd, not determined]

\begin{tabular}{|c|c|c|c|c|c|}
\hline Pebulate & .004 & $75.4-105$ & 97.5 & 90.8 & 79.1 \\
\hline Pendimethalin & .004 & $112-135$ & 126 & 127 & 117 \\
\hline cis-Permethrin & .005 & $80.8-106$ & 100 & 97.9 & 84.8 \\
\hline Phorate & .002 & $82.7-104$ & 94.4 & 85.7 & 104 \\
\hline Prometon & .018 & $90.0-114$ & 113 & 108 & 92.7 \\
\hline Pronamide & .003 & $109-123$ & 109 & 115 & 119 \\
\hline Propachlor & .007 & $106-155$ & 131 & 113 & 116 \\
\hline Propanil & .004 & $122-138$ & 126 & 123 & 134 \\
\hline Propargite & .013 & $89.6-105$ & 102 & 96.7 & 93.0 \\
\hline Simazine & .005 & $97.6-113$ & 111 & 108 & 102 \\
\hline Tebuthiuron & .010 & $137-179$ & 163 & 154 & 147 \\
\hline Terbacil & .007 & $84.4-131$ & 117 & 114 & 92.2 \\
\hline Terbufos & .013 & $93.2-107$ & 101 & 93.3 & 106 \\
\hline Thiobencarb & .002 & $115-123$ & 122 & 121 & 116 \\
\hline Triallate & .001 & $88.3-106$ & 102 & 103 & 89.0 \\
\hline Trifluralin & .002 & $118-144$ & 132 & 136 & 125 \\
\hline \multicolumn{6}{|c|}{ Surrogates } \\
\hline$\alpha-\mathrm{HCH}-d 6$ & nd & $102-130$ & 103 & 107 & 127 \\
\hline Diazinon- $d 10$ & nd & $113-127$ & 125 & 120 & 117 \\
\hline Terbuthylazine & nd & $121-141$ & 131 & 123 & 133 \\
\hline
\end{tabular}


Table 5. Reporting limits and percent recoveries for custom method 9090 volatile organic compound spikes [ $\mu \mathrm{g} / \mathrm{L}$, micrograms per liter; nd, not determined]

\begin{tabular}{|c|c|c|c|c|c|}
\hline \multirow[b]{2}{*}{ Compound } & \multirow[b]{2}{*}{$\begin{array}{l}\text { Reporting } \\
\text { limit }(\mu \mathrm{g} / \mathrm{L})\end{array}$} & \multirow[b]{2}{*}{$\begin{array}{l}\text { Range in } \\
\text { percent } \\
\text { recovery }\end{array}$} & \multicolumn{3}{|c|}{ Mean percent recovery } \\
\hline & & & Spike \#1 & Spike \#2 & Spike \#3 \\
\hline Bromodichloromethane & 0.100 & $78.3-104$ & 91.3 & 94.7 & 104 \\
\hline Bromoform & .200 & $84.2-110$ & 91.2 & 103 & 108 \\
\hline Carbon tetrachloride & .050 & $66.7-117$ & 83.3 & 87.5 & 114 \\
\hline Dibromochloromethane & .100 & $78.3-104$ & 86.9 & 94.5 & 100 \\
\hline 1,4-Dichlorobenzene & .050 & $64.0-84.0$ & 76.0 & 69.3 & 82.7 \\
\hline 1,2-Dichloroethane & .050 & $92.0-116$ & 98.7 & 96.0 & 115 \\
\hline 1,1-Dichloroethene & .100 & $75.0-121$ & 84.7 & 90.3 & 115 \\
\hline Ethylbenzene & .050 & $65.4-96.1$ & 83.3 & 79.5 & 83.3 \\
\hline MTBE & .100 & $86.9-104$ & 88.4 & 101 & 104 \\
\hline Tetrachloroethene & .050 & $70.0-100$ & 88.3 & 95.0 & 88.3 \\
\hline 1,1,1-Trichloroethane & .050 & $70.8-95.8$ & 84.7 & 84.7 & 94.4 \\
\hline Trichloroethene & .050 & $69.6-95.7$ & 86.9 & 88.4 & 92.7 \\
\hline Vinyl chloride & .100 & $66.7-104$ & 80.2 & 74.1 & 91.3 \\
\hline \multicolumn{6}{|c|}{ Surrogates } \\
\hline$p$-Bromofluorobenzene & nd & $77.0-95.0$ & 84.3 & 77.7 & 94.7 \\
\hline 1,2-Dichloroethane $d$-4 & nd & $94.0-112$ & 97.0 & 97.3 & 111 \\
\hline Toluene $d-8$ & nd & $95.0-101$ & 99.3 & 95.0 & 96.3 \\
\hline
\end{tabular}


Table 6. Reporting limits and concentrations of compounds with greater than five percent differences in concentrations in replicate samples

[mg/L, milligrams per liter; $\mu \mathrm{g} / \mathrm{L}$, micrograms per liter; $E$, detection with estimated concentration; --, less than five percent difference; <, less than; pCi/L, picoCuries per liter]

\begin{tabular}{|c|c|c|c|c|c|}
\hline \multirow[b]{2}{*}{ Compound } & \multirow[b]{2}{*}{$\begin{array}{l}\text { Reporting } \\
\text { limit and unit }\end{array}$} & \multicolumn{4}{|c|}{ Sample/replicate concentrations } \\
\hline & & Replicate \#1 & Replicate \#2 & Replicate \#3 & Replicate \#4 \\
\hline Nitrite-nitrogen & $0.010 \mathrm{mg} / \mathrm{L}$ & -- & -- & $<0.010 / 0.010$ & -- \\
\hline Phosphorus & $.010 \mathrm{mg} / \mathrm{L}$ & -- & $<0.010 / 0.020$ & -- & $0.010 /<0.010$ \\
\hline Dissolved organic carbon & $.10 \mathrm{mg} / \mathrm{L}$ & -- & $0.40 / 0.60$ & $0.40 / 0.50$ & $0.40 / 0.30$ \\
\hline Calcium & $.02 \mathrm{mg} / \mathrm{L}$ & $40 / 37$ & -- & -- & -- \\
\hline Sodium & $.20 \mathrm{mg} / \mathrm{L}$ & -- & $2.2 / 2.4$ & -- & -- \\
\hline Potassium & $.10 \mathrm{mg} / \mathrm{L}$ & $0.80 / 0.90$ & -- & $1.3 / 1.2$ & -- \\
\hline Chloride & $.10 \mathrm{mg} / \mathrm{L}$ & -- & $4.0 / 3.8$ & $0.50 / 0.60$ & -- \\
\hline Bromide & $.01 \mathrm{mg} / \mathrm{L}$ & -- & -- & $0.090 / 0.070$ & -- \\
\hline Iron & $3.0 \mu \mathrm{g} / \mathrm{L}$ & -- & $9.0 / 11$ & -- & -- \\
\hline Barium & $1.0 \mu \mathrm{g} / \mathrm{L}$ & -- & $4.0 / 3.0$ & -- & -- \\
\hline Chromium & $1.0 \mu \mathrm{g} / \mathrm{L}$ & $7.0 / 6.0$ & $3.0 / 2.0$ & -- & -- \\
\hline Copper & $1.0 \mu \mathrm{g} / \mathrm{L}$ & $19 / 17$ & $1.0 /<1.0$ & -- & -- \\
\hline Molybdenum & $1.0 \mu \mathrm{g} / \mathrm{L}$ & -- & -- & $1.0 / 2.0$ & -- \\
\hline Nickel & $1.0 \mu \mathrm{g} / \mathrm{L}$ & $1.0 /<1.0$ & -- & $2.0 / 3.0$ & -- \\
\hline Zinc & $1.0 \mu \mathrm{g} / \mathrm{L}$ & $3.0 / 4.0$ & -- & $40 / 38$ & -- \\
\hline Aluminum & $1.0 \mu \mathrm{g} / \mathrm{L}$ & -- & $4.0 / 3.0$ & $5.0 / 3.0$ & -- \\
\hline Radon & $80.0 \mathrm{pCi} / \mathrm{L}$ & $690 / 740$ & -- & $230 / 280$ & $190 / 170$ \\
\hline Atrazine & $.001 \mu \mathrm{g} / \mathrm{L}$ & -- & $0.009 / 0.010$ & -- & -- \\
\hline Deethylatrazine & $.002 \mu \mathrm{g} / \mathrm{L}$ & -- & $\mathrm{E} 0.004 / \mathrm{E} 0.005$ & -- & -- \\
\hline Chlorobenzene & $.050 \mu \mathrm{g} / \mathrm{L}$ & -- & -- & -- & $\mathrm{E} 0.001 /<0.050$ \\
\hline Methyl chloride & $.200 \mu \mathrm{g} / \mathrm{L}$ & -- & -- & $<0.200 / \mathrm{E} 0.010$ & E $0.010 /<0.200$ \\
\hline Tetrachloroethene & $.050 \mu \mathrm{g} / \mathrm{L}$ & -- & -- & $\mathrm{E} 0.004$ / E0.005 & -- \\
\hline Carbon disulfide & $.050 \mu \mathrm{g} / \mathrm{L}$ & -- & -- & $\mathrm{E} 0.080 / \mathrm{E} 0.050$ & $\mathrm{E} 0.008 / \mathrm{E} 0.007$ \\
\hline Methyl ethyl ketone & $5.0 \mu \mathrm{g} / \mathrm{L}$ & -- & -- & $\mathrm{E} 0.200 / \mathrm{E} 0.100$ & -- \\
\hline
\end{tabular}


Table 7. Medians, standard deviations, and ranges in values of concentrations of major ions dissolved in water samples from Prairie du Chien-Jordan study area wells

[Concentrations in $\mathrm{mg} / \mathrm{L}$ ]

\begin{tabular}{|c|c|c|c|c|c|c|}
\hline \multirow{2}{*}{ Constituent } & \multicolumn{3}{|c|}{ Unconfined portion of aquifer } & \multicolumn{3}{|c|}{ Confined portion of aquifer } \\
\hline & Median & $\begin{array}{l}\text { Standard } \\
\text { deviation }\end{array}$ & Range & Median & $\begin{array}{l}\text { Standard } \\
\text { deviation }\end{array}$ & Range \\
\hline Calcium & 62 & 16.9 & $36-93$ & 69.5 & 19.3 & $32-98$ \\
\hline Magnesium & 24 & 6.2 & $14-35$ & 29 & 9.3 & $14-47$ \\
\hline Hardness, as $\mathrm{CaCO}_{3}$ & 253 & 65 & $153-376$ & 282 & 82 & $137-438$ \\
\hline Sodium & 3.4 & 1.8 & $1.9-11$ & 5.1 & 7.2 & $1.9-30$ \\
\hline Potassium & 1.2 & 0.6 & $0.6-3$ & 1.4 & 1.0 & $0.5-3.6$ \\
\hline Chloride & 3.7 & 6.3 & $0.2-20$ & 1.5 & 6.3 & $0.2-25$ \\
\hline Sulfate & 16 & 12.7 & $0.4-56$ & 21 & 13.6 & $0.8-53$ \\
\hline Fluoride & 0.1 & 0.1 & $<0.10-0.4$ & 0.2 & 0.1 & $<0.10-0.3$ \\
\hline Bromide & 0.04 & 0.02 & $0.02-0.09$ & 0.04 & 0.02 & $0.02-0.11$ \\
\hline Silica & 18 & 4.5 & $11-26$ & 19.5 & 5.3 & $9.5-30$ \\
\hline
\end{tabular}

Table 8. Number of samples with detectable concentrations, reporting limits, median values, standard deviations, and ranges in concentrations of nutrients and dissolved organic carbon in water samples from wells in the unconfined and confined portions of the Prairie du Chien-Jordan study area

[Concentrations in $\mathrm{mg} / \mathrm{L}$; values for confined portion of the aquifer in parentheses]

\begin{tabular}{|c|c|c|c|c|c|}
\hline Constituent & $\begin{array}{l}\text { Number of } \\
\text { samples with } \\
\text { detectable } \\
\text { concentrations }\end{array}$ & $\begin{array}{l}\text { Reporting } \\
\text { limit }\end{array}$ & Median & $\begin{array}{l}\text { Standard } \\
\text { deviation }\end{array}$ & Range \\
\hline Nitrite-nitrogen & $11(2)$ & 0.010 & $<0.01(<0.01)$ & $0.005(0.003)$ & $\begin{array}{l}<0.01-0.01 \\
(<0.01-0.01)\end{array}$ \\
\hline Ammonia-nitrogen & $22(22)$ & .015 & $0.02(0.09)$ & $0.19(0.26)$ & $\begin{array}{c}<0.015-0.94 \\
(<0.015-0.77)\end{array}$ \\
\hline Ammonia + organic-nitrogen & $2(10)$ & .20 & $<0.20(<0.20)$ & $0.2(0.3)$ & $\begin{array}{c}<0.20-1.0 \\
(<0.20-0.80)\end{array}$ \\
\hline Nitrate-nitrogen & $21(16)$ & .050 & $0.64(0.09)$ & $4.23(2.28)$ & $\begin{array}{l}<0.05-17.0 \\
(<0.05-8.4)\end{array}$ \\
\hline Phosphorus & $10(11)$ & .01 & $<0.01(<0.01)$ & $0.02(0.02)$ & $\begin{array}{c}<0.01-0.07 \\
(<0.01-0.07)\end{array}$ \\
\hline Orthophosphorus & $22(17)$ & .01 & $0.02(0.02)$ & $0.02(0.01)$ & $\begin{array}{c}<0.01-0.07 \\
(<0.01-0.04)\end{array}$ \\
\hline Dissolved organic carbon & $25(25)$ & .10 & $0.5(0.7)$ & $0.3(0.4)$ & $\begin{array}{c}0.20-1.5 \\
(0.30-1.8)\end{array}$ \\
\hline
\end{tabular}

${ }^{1}$ Samples from 25 wells completed in the unconfined portion of the Prairie du Chien-Jordan aquifer were analyzed for nutrients. Samples from 24 of 25 wells completed in the confined portion of the Prairie du Chien-Jordan aquifer were analyzed for nutrients; all samples were analyzed for dissolved organic carbon. 
Table 9. Number of samples with detectable concentrations, reporting limits, median values, standard deviations, ranges in concentrations, and maximum contaminant levels of trace metals in water samples from wells in the unconfined and confined portions of the Prairie du Chien-Jordan study area

[Concentrations in micrograms per liter ( $\mu \mathrm{g} / \mathrm{L}$ ); values from the confined portion of the aquifer in parenthesis; -- , not applicable; $<$, less than; MCL, Maximum Contaminant Level; SMCL, Secondary Maximum Contaminant Level]

\begin{tabular}{|c|c|c|c|c|c|c|}
\hline Trace metal & $\begin{array}{l}\text { Number of } \\
\text { samples with } \\
\text { detectable } \\
\text { concentrations }\end{array}$ & $\begin{array}{l}\text { Reporting } \\
\text { limit }\end{array}$ & Median & $\begin{array}{l}\text { Standard } \\
\text { deviation }\end{array}$ & Range & $\begin{array}{l}\text { MCL or } \\
\text { SMCL }\end{array}$ \\
\hline Iron & $17(19)$ & 3.0 & $12(180)$ & $835(1,212)$ & $\begin{array}{c}<3.0-3500 \\
(<3.0-4,300)\end{array}$ & $1_{300}$ \\
\hline Zinc & $25(25)$ & 1.0 & $85(13)$ & $77(155)$ & $\begin{array}{c}12-290 \\
(3.0-659)\end{array}$ & ${ }^{1} 5,000$ \\
\hline Manganese & $17(19)$ & 1.0 & $4.0(61)$ & $170(220)$ & $\begin{array}{c}<1.0-770 \\
(<1.0-1,040)\end{array}$ & $1_{50}$ \\
\hline Barium & $24(25)$ & 1.0 & $28(27)$ & $73(71)$ & $\begin{array}{c}1.0-329 \\
(1.0-237)\end{array}$ & 2,000 \\
\hline Chromium & $24(25)$ & 1.0 & $4.0(5.0)$ & $1.5(1.7)$ & $\begin{array}{l}<1.0-7.0 \\
(2.0-7.0)\end{array}$ & 100 \\
\hline Aluminum & $24(25)$ & 1.0 & $3.0(3.0)$ & $2.6(0.4)$ & $\begin{array}{l}<1.0-15 \\
(2.0-4.0)\end{array}$ & None \\
\hline Copper & $14(11)$ & 1.0 & $3.0(<1.0)$ & $10.5(8.0)$ & $\begin{array}{l}<1.0-35 \\
(<1.0-23)\end{array}$ & ${ }^{1} 1,000$ \\
\hline Nickel & $24(23)$ & 1.0 & $2.0(2.0)$ & $4.0(1.1)$ & $\begin{array}{c}<1.0-22 \\
(<1.0-4.0)\end{array}$ & None \\
\hline Molybdenum & $10(15)$ & 1.0 & $<1.0(1.0)$ & $1.7(1.3)$ & $\begin{array}{l}<1.0-8.0 \\
(<1.0-4.0)\end{array}$ & None \\
\hline Uranium & $7(9)$ & 1.0 & $<1.0(<1.0)$ & $1.1(1.3)$ & $\begin{array}{l}<1.0-5.0 \\
(<1.0-4.0)\end{array}$ & ${ }^{2} 20$ \\
\hline Arsenic & $3(3)$ & 1.0 & $<1.0(<1.0)$ & $0.6(1.5)$ & $\begin{array}{l}<1.0-3.0 \\
(<1.0-7.0)\end{array}$ & 50 \\
\hline Selenium & $2(2)$ & 1.0 & $<1.0(<1.0)$ & $0.3(0.5)$ & $\begin{array}{l}<1.0-1.0 \\
(<1.0-2.0)\end{array}$ & 50 \\
\hline Lead & $0(3)$ & 1.0 & $<1.0(<1.0)$ & $--(0.7)$ & $\begin{array}{c}\quad<1.0 \\
(<1.0-2.0)\end{array}$ & Nondetectable \\
\hline Cobalt & $2(0)$ & 1.0 & $<1.0(<1.0)$ & $0.8(--)$ & $\begin{aligned}<1.0-4.0 \\
(<1.0)\end{aligned}$ & None \\
\hline Antimony & $0(0)$ & 1.0 & $<1.0(<1.0)$ & -- (--) & $\begin{array}{l}<1.0 \\
(<1.0)\end{array}$ & 6 \\
\hline Beryllium & $0(0)$ & 1.0 & $<1.0(<1.0)$ & -- (--) & $\begin{array}{l}<1.0 \\
(<1.0)\end{array}$ & 4 \\
\hline Cadmium & $0(0)$ & 1.0 & $<1.0(<1.0)$ & $--(--)$ & $\begin{array}{l}<1.0 \\
(<1.0)\end{array}$ & 5 \\
\hline Silver & $0(0)$ & 1.0 & $<1.0(<1.0)$ & -- (--) & $\begin{array}{l}<1.0 \\
(<1.0)\end{array}$ & ${ }^{1} 100$ \\
\hline
\end{tabular}

${ }^{1}$ SMCL

${ }^{2}$ Proposed MCL 
Table 10. Pesticide compounds analyzed in water samples, by chemical class

\begin{tabular}{ccc}
\hline Triazines & Phosphorothioates & Carbamates \\
Atrazine & Diazinon & Butylate \\
Cyanazine & Chloroacetanilides & Carbaryl \\
Deethylatrazine & Alachlor & Carbofuran \\
Metribuzin & 2,6 -Diethylanaline & EPTC (Eptam) \\
Prometon & Metolachlor & Molinate \\
Simazine & Sulfite Ester & Pebulate \\
Pyrethroid & Propargite & Thiobencarb \\
cis-Permethrin & Organochlorines & Triallate \\
Phenyl Ureas & $p$ - $p^{\prime}$-DDE & Dinitroaniline \\
Linuron & Dieldrin & Benfluralin \\
Tebuthiuron & $\alpha$-HCH & Ethalfluralin \\
Organophosphorus & $\gamma$-HCH (Lindane) & Pendimethalin \\
Azinphos-methyl & Amides & Trifluralin \\
Disulfoton & Napropamide & Hydroxy Acid \\
Ethoprop & Pronamide & Terbacil \\
Fonofos & Propachlor & Pyridazinone \\
Malathion & Propanil & Chlorpyrifos \\
Methyl parathion & Acetanilides & Other \\
Parathion & Acetochlor & Dacthal (DCPA) \\
Phorate & & \\
Terbufos & & \\
\hline & & \\
\hline & & \\
\hline
\end{tabular}


Table 11. Reporting limits, number of samples with detectable concentrations, ranges in concentrations, and maximum contaminant levels of pesticide compounds in water samples from Prairie du Chien-Jordan study area wells

[ $\mu \mathrm{g} / \mathrm{L}$, micrograms per liter; $\mathrm{E}$, detection with estimated concentration]

\begin{tabular}{|c|c|c|c|c|c|c|}
\hline \multirow[b]{2}{*}{ Compound } & \multirow[b]{2}{*}{$\begin{array}{c}\text { Reporting } \\
\text { limit } \\
(\mu \mathrm{g} / \mathrm{L})\end{array}$} & \multicolumn{2}{|c|}{ Unconfined portion of aquifer } & \multicolumn{2}{|c|}{ Confined portion of aquifer } & \multirow[b]{2}{*}{$\begin{array}{c}\text { Maximum } \\
\text { contaminant } \\
\text { level } \\
(\mu \mathrm{g} / \mathrm{L})\end{array}$} \\
\hline & & $\begin{array}{l}\text { Number (and } \\
\text { percent) of } \\
\text { samples with } \\
\text { detectable } \\
\text { concentrations }\end{array}$ & $\begin{array}{c}\text { Range in } \\
\text { concentration } \\
(\mu \mathrm{g} / \mathrm{L})\end{array}$ & $\begin{array}{l}\text { Number (and } \\
\text { percent) of water } \\
\text { samples with } \\
\text { detectable } \\
\text { concentrations }\end{array}$ & $\begin{array}{c}\text { Range in } \\
\text { concentration } \\
(\mu \mathrm{g} / \mathrm{L})\end{array}$ & \\
\hline Atrazine & 0.001 & $13(52 \%)$ & $<0.001-2.80$ & $9(36 \%)$ & $<0.001-0.344$ & 3.0 \\
\hline Deethylatrazine & .002 & $14(56 \%)$ & $<0.002-\mathrm{E} 0.616$ & $9(36 \%)$ & $<0.002-\mathrm{E} 0.325$ & None \\
\hline Simazine & .005 & $3(12 \%)$ & $<0.005-0.010$ & $2(8 \%)$ & $<0.005-0.036$ & 4.0 \\
\hline Diazinon & .002 & $2(8 \%)$ & $<0.002-0.026$ & $2(8 \%)$ & $<0.002-19.0$ & None \\
\hline Metolachlor & .002 & $1(4 \%)$ & $<0.002-0.004$ & $1(4 \%)$ & $<0.002-0.012$ & None \\
\hline Alachlor & .002 & $1(4 \%)$ & $<0.002-1.30$ & 0 & $<0.002$ & 2.0 \\
\hline 2,6-Diethylanaline & .003 & $1(4 \%)$ & $<0.003-\mathrm{E} 0.003$ & 0 & $<0.003$ & None \\
\hline
\end{tabular}


Table 12. Volatile organic compounds analyzed in water samples, by chemical class

Halogenated Alkanes

Bromomethane

Chloroethane

1,2-Dibromo-3-chloropropane

1,2-Dibromoethane

1,1-Dichloroethane

1,2-Dichloroethane

1,2-Dichloropropane

1,3-Dichloropropane

2,2-Dichloropropane

Hexachloroethane

Methyl chloride (Chloromethane)

Methylene chloride (Dichloromethane)

1,1,1,2-Tetrachloroethane

1,1,2,2-Tetrachloroethane

1,1,1-Trichloroethane

1,1,2-Trichloroethane

1,2,3-Trichloropropane

Chlorofluorocarbons

Dichlorodifluoromethane (CFC-12)

Tetrachloromethane (Carbon tetrachloride)

Trichlorofluoromethane (CFC-11)

1,1,2-Trichlorotrifluoromethane (CFC-113)

Aldehydes

Acrolein

Acrylonitrile (2-Propenitrile)

Ketones

2-Butanone (Methyl ethyl ketone)

2-Hexanone

Methyl isobutyl ketone (Hexanone)

\section{Halogenated Alkenes}

3-Chloropropene

1,1-Dichloroethene

cis-1,2-Dichloroethene

trans-1,2-Dichlorethene

1,1-Dichloropropene

cis-1,3-Dichloropropene

trans-1,3-Dichloropropene

Hexachlorobutadiene

Tetrachloroethene

Trichloroethene

Vinyl bromide (Bromoethene)

Vinyl chloride (Chloroethene)

\section{Alkenes}

Vinyl acetate

Halogenated Aromatics

Bromobenzene

Chlorobenzene

1,2-Dichlorobenzene

1,3-Dichlorobenzene

1,4-Dichlorobenzene

Methyl iodide

1,2,3-Trichlorobenzene

1,2,4-Trichlorobenzene

Aromatic Hydrocarbons

Benzene

Naphthalene

Styrene

Trihalomethanes

Bromochloromethane

Bromodichloromethane

Bromoform (Tribromomethane)

Chloroform (Trichloromethane)

Dibromochloromethane
Alkylated Benzenes

n-Butylbenzene

sec-Butylbenzene

tert-Butylbenzene

2-Chlorotoluene

4-Chlorotoluene

Ethylbenzene

$o$-Ethyl toluene

Isopropylbenzene

p-Isopropyltoluene

$n$-Propylbenzene

1,2,3,4-Tetramethylbenzene

1,2,3,5-Tetramethylbenzene

Toluene

1,2,3-Trimethylbenzene

1,2,4-Trimethylbenzene

1,3,5-Trimethylbenzene

meta- and para-Xylene

ortho-Xylene

Ethers

tert-Butyl ethyl ether

tert-Butyl methyl ether (MTBE)

Diethyl ether

tert-Pentyl methyl ether

Tetrahydrofuran

\section{Others}

Acetone

Carbon disulfide

trans-1,4-Dichloro-2-butene

Diisopropyl ether

Ethyl methacrylate

Methyl acrylate

Methyl acrylonitrile

Methyl methacrylate

Dibromomethane 
Table 13. Reporting limits, number of samples with detectable concentrations, ranges in concentrations, and maximum contaminant levels of volatile organic compounds detected in water samples from Prairie du Chien-Jordan study area wells

[ $\mu \mathrm{g} / \mathrm{L}$, micrograms per liter; $\mathrm{E}$, detection with estimated concentration]

\begin{tabular}{|c|c|c|c|c|c|c|}
\hline \multirow[b]{2}{*}{ Compound } & \multirow[b]{2}{*}{$\begin{array}{l}\text { Reporting } \\
\text { limit }(\mu \mathrm{g} / \mathrm{L})\end{array}$} & \multicolumn{2}{|c|}{ Unconfined portion of aquifer } & \multicolumn{2}{|c|}{ Confined portion of aquifer } & \multirow[b]{2}{*}{$\begin{array}{c}\text { Maximum } \\
\text { contaminant } \\
\text { level }(\mu \mathrm{g} / \mathrm{L})\end{array}$} \\
\hline & & $\begin{array}{l}\text { Number (and } \\
\text { percent) of } \\
\text { samples with } \\
\text { detected } \\
\text { concentrations }\end{array}$ & $\begin{array}{c}\text { Range in } \\
\text { concentration } \\
(\mu \mathrm{g} / \mathrm{L})\end{array}$ & $\begin{array}{l}\text { Number (and } \\
\text { percent) of } \\
\text { detections in } \\
\text { water samples }\end{array}$ & $\begin{array}{c}\text { Range in } \\
\text { concentration } \\
(\mu \mathrm{g} / \mathrm{L})\end{array}$ & \\
\hline Carbon disulfide & 0.050 & $11(44 \%)$ & $<0.050-\mathrm{E} 0.080$ & $15(60 \%)$ & $<0.050-\mathrm{E} 0.050$ & None \\
\hline Methyl chloride & .200 & $11(44 \%)$ & $<0.200-\mathrm{E} 0.070$ & $9(36 \%)$ & $<0.200-\mathrm{E} 0.060$ & None \\
\hline 1,2,4-Trimethylbenzene & .200 & $4(16 \%)$ & $<0.050-0.160$ & $8(32 \%)$ & $<0.050-\mathrm{E} 0.060$ & None \\
\hline Bromoform & .200 & $6(24 \%)$ & $<0.200-0.130$ & $4(16 \%)$ & $<0.200-\mathrm{E} 0.010$ & ${ }^{1} 100$ \\
\hline Chloroform & .050 & $4(16 \%)$ & $<0.050-0.120$ & $3(12 \%)$ & $<0.050-\mathrm{E} 0.030$ & ${ }^{1} 100$ \\
\hline Chlorobenzene & .050 & $3(12 \%)$ & $<0.050-\mathrm{E} 0.003$ & $2(8 \%)$ & $<0.050-\mathrm{E} 0.002$ & 100 \\
\hline Methylene chloride & .100 & $1(4 \%)$ & $<0.100-\mathrm{E} 0.020$ & $3(12 \%)$ & $<0.100-\mathrm{E} 0.020$ & 5.0 \\
\hline Trichlorofluoromethane & .100 & $2(8 \%)$ & $<0.100-\mathrm{E} 0.010$ & $1(4 \%)$ & $<0.100-\mathrm{E} 0.010$ & None \\
\hline Tetrachloroethene & .050 & $2(8 \%)$ & $<0.050-\mathrm{E} 0.004$ & $1(4 \%)$ & $<0.050-\mathrm{E} 0.003$ & 5.0 \\
\hline Dichlorodifluoromethane & .200 & $3(12 \%)$ & $<0.200-\mathrm{E} 0.440$ & 0 & $<0.200$ & None \\
\hline Methyl iodide & .050 & 0 & $<0.050$ & $2(8 \%)$ & $<0.050-\mathrm{E} 0.020$ & None \\
\hline Acetone & 5.00 & $1(4 \%)$ & $<5.00-\mathrm{E} 0.400$ & $1(4 \%)$ & $<5.00-\mathrm{E} 0.500$ & None \\
\hline Methyl ethyl ketone & 5.00 & $1(4 \%)$ & $<5.00-\mathrm{E} 0.200$ & $1(4 \%)$ & $<5.00-\mathrm{E} 0.200$ & None \\
\hline Benzene & .050 & $1(4 \%)$ & $<0.050-\mathrm{E} 0.020$ & $1(4 \%)$ & $<0.050-\mathrm{E} 0.020$ & 5.0 \\
\hline Trichloroethene & .050 & $1(4 \%)$ & $<0.050-0.180$ & 0 & $<0.050$ & 5.0 \\
\hline Chloroethane & .100 & $1(4 \%)$ & $<0.100-\mathrm{E} 0.060$ & 0 & $<0.100$ & None \\
\hline Bromodichloromethane & .100 & $1(4 \%)$ & $<0.100-0.200$ & 0 & $<0.100$ & $' 100$ \\
\hline Dibromochloromethane & .100 & $1(4 \%)$ & $<0.100-0.310$ & 0 & $<0.100$ & ${ }^{1} 100$ \\
\hline$p$-Isopropyltoluene & .050 & $1(4 \%)$ & $<0.050-\mathrm{E} 0.002$ & 0 & $<0.050$ & None \\
\hline 1,1,1-Trichloroethane & .050 & 0 & $<0.050$ & $1(4 \%)$ & $<0.050-\mathrm{E} 0.004$ & 200 \\
\hline Toluene & .050 & 0 & $<0.050$ & $1(4 \%)$ & $<0.050-0.920$ & 1,000 \\
\hline $\begin{array}{l}\text { tert-Butyl methyl ether } \\
\text { (MTBE) }\end{array}$ & .100 & 0 & $<0.100$ & $1(4 \%)$ & $<0.100-\mathrm{E} 0.010$ & None \\
\hline
\end{tabular}

\footnotetext{
${ }^{\mathrm{I}}$ The MCL for trihalomethanes is $100 \mu \mathrm{g} / \mathrm{L}$ for the sum of the concentrations of those compounds.
} 
